\title{
O RETORNO FINANCEIRO DAS ATIVIDADES REALIZADAS PELA ENFERMAGEM EM UMA UNIDADE DE TERAPIA INTENSIVA
}

Versão corrigida

Dissertação apresentada ao programa de Pós-Graduação em Gerenciamento de Enfermagem da Escola de Enfermagem da Universidade de São Paulo para obtenção do título de Mestre em Ciências.

Área de Concentração: Fundamentos e Práticas de Gerenciamento em Enfermagem e em Saúde

Orientadora: Prof ${ }^{a}$ Dr $^{a}$ Valéria Castilho

$$
\text { São Paulo - SP }
$$




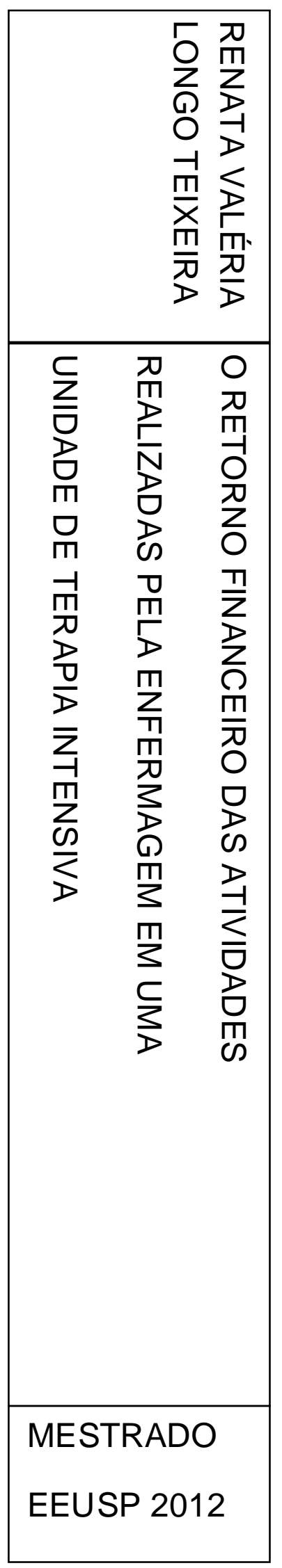


AUTORIZO A REPRODUÇÃO E DIVULGAÇÃO TOTAL OU PARCIAL DESTE TRABALHO, POR QUALQUER MEIO CONVENCIONAL OU ELETRÔNICO, PARA FINS DE ESTUDO E PESQUISA, DESDE QUE CITADA A FONTE.

Assinatura:

Data:

\section{Catalogação na Publicação (CIP)}

Biblioteca "Wanda de Aguiar Horta"

Escola de Enfermagem da Universidade de São Paulo

Teixeira, Renata Valeria Longo

O retorno financeiro das atividades realizadas pela

enfermagem em uma unidade de terapia intensiva /

Renata Valeria Longo Teixeira. - São Paulo, 2012.

$101 \mathrm{p}$.

Dissertação (Mestrado) - Escola de Enfermagem da

Universidade de São Paulo.

Orientadora: Profa Drạ Valéria Castilho

Área de concentração: Fundamentos e práticas de

gerenciamento em enfermagem e em saúde

1. Custos dos cuidados de saúde 2 . Serviços de enfermagem 3.

Enfermagem - Auditoria 4. Faturamento 5. Unidades de tera pia intensiva Custos I. Título. 
Folha de Aprovação

Renata Valéria Longo Teixeira

O retorno financeiro das atividades realizadas pela enfermagem em uma Unidade de Terapia Intensiva.

Dissertação apresentada ao Programa de Pós-Graduação em Gerenciamento de Enfermagem da Escola de Enfermagem da Universidade de São Paulo para obtenção do título de Mestre em Ciências.

Aprovado em:

Banca Examinadora

Prof. Dr.:

Instituição:

Julgamento:

Assinatura:

Prof. Dr.:

Instituição:

Julgamento:

Assinatura:

Prof. Dr.:

Instituição:

Julgamento:

Assinatura: 


\section{DEDICATÓRIA}

Dedico este trabalho a meus familiares: minha mãe Esmeralda, minha irmã Ana Paula, meu marido Luis e minha sogra D. Isabel, por acreditarem em mim e apoiarem-me sempre.

A meus "anjos" de 4 patas: Nina, Ralph e Clara, pelas companhias silenciosas e amorosas durante todo este trabalho. 


\section{AGRADECIMENTOS}

A Deus, pelo dom da vida.

À minha família, pelo apoio incondicional.

A meu marido, Luis, pelo amor, paciência, respeito, carinho, apoio e compreensão durante toda a realização deste trabalho. Por me incentivar e ajudar, sempre. Meu amor eterno.

À Prof ${ }^{a}$ Dra. Valéria Castilho, pela paciência e horas trabalhadas. Muito obrigada.

A meus amigos, em especial minha irmã japonesa Lisa, pela compreensão das minhas ausências durante a realização desta obra.

A Andréia Santana, um exemplo de profissional e uma amiga que me incentivou a começar este trabalho.

À bibliotecária Nadir Lopes, pelas orientações e conselhos tão valiosos. 
A meu professor Sérgio Rorato, por realizar as traduções e pelo carinho e ajuda na fase final de meu trabalho.

Aos colaboradores do SAME, Marlene, Lucimara, Patrícia, Ricardo e Sara, pelo carinho e dedicação durante a coleta dos dados. Muito obrigada.

Aos profissionais da Secretaria de Pós-graduação da EEUSP, pela disponibilidade e atenção. 


\section{EPÍGRAFE}

Para ser grande, sê inteiro: nada

Teu exagera ou exclui.

Sê todo em cada coisa. Põe quanto és

No mínimo que fazes.

Assim em cada lago a lua toda

Brilha, porque alta vive.

\section{Ricardo Reis}

"I used to be on an endless run.

Believe in miracles 'cause I'm one.

A have been blessed with the power to survive.

After all these years I'm still alive.

I'm out here cookin' with the band.

I'm no longer a solitary man.

Every day my time runs out.

Lived like a fool, that's what I was about, oh.

I believe in miracles.

I believe in a better world for me and you.

Oh, I believe in miracles.

I believe in a better world for me and you.

I close my eyes and think how it might be.

The future's here today.

It's not too late".

I believe in miracles - Ramones 


\section{RESUMO}

Teixeira RVT. O retorno financeiro das atividades realizadas pela enfermagem em uma Unidade de Terapia Intensiva [Dissertação]. São Paulo, 2012. 101p. Escola de Enfermagem, Universidade de São Paulo.

$O$ enfermeiro tem sido cada vez mais requisitado para envolver-se nas decisões financeiras nas organizações de saúde. Sua participação no gerenciamento dos custos associado à assistência de enfermagem é importante para conhecer 0 quanto a enfermagem contribui para $o$ faturamento de uma Unidade de Terapia Intensiva (UTI) e ao faturamento de um hospital e evidenciar, financeiramente, a relevância do trabalho desse profissional. No entanto, a literatura brasileira carece de estudos nesse aspecto. $\mathrm{O}$ objetivo deste estudo foi levantar o valor do faturamento gerado pelos procedimentos de enfermagem, mediante as prescrições médica e de enfermagem, identificar as atividades de enfermagem que são realizadas, mas não recebem pagamento pelas operadoras de saúde e estimar a perda monetária do hospital pela não taxação das atividades de enfermagem, em uma. Tratou-se de um estudo de caso exploratório, descritivo, com abordagem quantitativa. $O$ estudo foi desenvolvido na UTI Cardiológica de um hospital geral filantrópico, com 319 leitos, na cidade de São Paulo. A amostra total calculada para 3 meses foi de 168 pacientes. $O$ faturamento médio gerado pelas prescrições de enfermagem e médica foi de $R \$ 773,98$, e $R \$ 333,06$ corresponderam à prescrição de enfermagem e $R \$ 440,92$, à prescrição médica. Em relação ao valor gerado pela prescrição de enfermagem ( $R \$ 333,06), R \$ 261,67$ corresponderam ao pagamento de materiais de consumo e $R \$ 71,39$, ao pagamento de taxas. Em relação ao valor gerado pela prescrição médica ( $R \$ 440,92), \quad R \$ 322,51$ corresponderam ao pagamento de materiais de consumo e $R \$ 118,41$, ao pagamento de taxas. Os procedimentos da prescrição de enfermagem que mais contribuíram para o faturamento foram a troca de filtro bacteriano $(R \$$ $10.342,80)$, a realização de punção venosa ( $R \$ 8.062,99)$, o curativo de ferida operatória $(R \$ 5.315,26)$ e o curativo de traqueostomia $(R \$ 4.762,42)$. Os procedimentos provenientes da prescrição médica que mais geraram faturamento foram a realização de glicemia capilar $(R \$ 21.602,06)$, passagem de pressão arterial invasiva ( $R \$ 14.220,56)$ e a passagem de sonda gástrica/enteral $(R \$ 20.239,00)$. A perda média estimada foi de $R \$$ 480,65 por paciente da amostra. A estimativa média de perda para a amostra estudada foi de $R \$ 81.263,65$. A projeção de perda média de faturamento, para o período dos 3 meses do estudo, para a amostra selecionada, foi de $R \$ 153.391,15$. A extrapolação da estimativa de perda média para o período de um ano, para a amostra selecionada, foi de $R \$$ 613.564,60. Do faturamento total da amostra selecionada, as atividades de enfermagem contribuíram com $1,7 \%$ do faturamento, e $0,65 \%$ corresponderam aos procedimentos executados mediante a prescrição de enfermagem e $1,05 \%$, aos procedimentos provenientes da prescrição médica. 
DESCRITORES: Custo e análise de custo. Serviços de enfermagem. Custos hospitalares. Auditoria em enfermagem. Faturamento. 


\begin{abstract}
Teixeira RVT. The financial return of the activities performed by nursing in an intensive care unit. [Dissertação]. São Paulo, 2012. 101p. Escola de Enfermagem, Universidade de São Paulo.

Nurses have increasingly been asked to participate in financial decisions in healthcare organizations. Their participation in managing the costs of nursing care is important to know how nursing contributes to the turnover of an ICU and hospital billing, and, it shows, financially, the relevance of the work of these professionals. However, Brazilian literature lacks studies in this regard. The objective of this study was to raise the value of the revenue generated by nursing procedures by the medical and nursing requirements, to identify nursing activities that are performed but not paid by health insurance companies and to estimate the monetary loss of the hospital for not taxing nursing activities in an intensive care unit (ICU). It was an occurrence study, exploratory, descriptive in a quantitative approach. The study was conducted in the Cardiology ICU of a philantropic general hospital, with 319 beds in the city of Sao Paulo. The total sample calculated for three months was 168 patients. The sources of information were the medical and accounting records of selected patients. The average revenue generated by medical and nursing prescriptions was $\mathrm{R} \$ 773,98$ which $\mathrm{R} \$ 333,06$ corresponded to the nursing prescription and $R \$ 440,92$, the medical one. In relation to the value generated by the nursing prescription $(R \$ 333,06), R \$ 261,67$ corresponded to the payment of consumables and $R \$ 71,39$ to fees. For the value generated by the prescription ( $R \$ 440,92), R \$ 322,51$ corresponded to the payment of consumables and $R \$ 118,41$, the payment of fees. The procedures of nursing prescription which most contributed to revenue were the exchange of bacteria filter $(R \$ 10.342,80)$, performing venipuncture $(R \$$ $8.062,99)$, the surgical wound dressing ( $R \$ 5,315.26)$ and tracheostomy dressing $(\mathrm{R} \$ 4.762,42)$. The procedures from prescription which most generated revenues were performing capillary blood glucose $(R \$ 21.602,06)$, passage of invasive blood pressure $(R \$ 14.220,56)$ and passage of nasogastric tube / enteral $(R \$ 20.239,00)$. The average loss was estimated at $\mathrm{R} \$ 480,65$ per patient sample. The average estimate of loss for the sample studied was $R \$ 81.263,65$. The projected average loss of revenue for the period of three months of the study, for the sample selected, was $R \$$ 153.391,15. The extrapolation of the estimated average loss for the period of one year, for the selected sample, was $R \$ 613.564,60$. From the total revenue of the selected sample, nursing activities accounted for $1.7 \%$ of revenues, and $0.65 \%$ corresponded to the procedures performed by nursing prescription and $1.05 \%$ corresponded to the procedures from the doctor's prescription.
\end{abstract}

Keywords: Cost and cost analysis. Nursing services. Hospital costs. Audit in nursing. Billing. 


\section{LISTA DE FIGURAS}

Figura 1 - Comparação múltipla entre as três principais operadoras de plano de assistência à saúde e grupo de outras operadoras, em relação ao faturamento pela prescrição médica - São Paulo - 2011 .............................69 


\section{LISTA DE TABELAS}

Tabela 1 - Demonstrativo sobre o total de pacientes internados na UTI Cardiológica nos meses entre janeiro e março de 2011 - São Paulo 2011. 31

Tabela 2 - Distribuição dos pacientes estudados, nos meses entre janeiro e março de 2011 - São Paulo - 2011

Tabela 3 - Distribuição dos pacientes conforme gênero, nos meses entre janeiro e março de 2011 - São Paulo - 2011 32

Tabela 4 - Demonstrativo da idade média dos pacientes do estudo, o tempo médio de internação na UTI Cardiológica e o tempo médio de internação hospitalar, nos meses entre janeiro e março de 2011 - São Paulo $-2011$

Tabela 5 - Demonstrativo sobre a classificação dos diagnósticos médicos de internação dos pacientes do estudo, nos meses entre janeiro e março de 2011 - São Paulo - 2011 34

Tabela 6 - Distribuição das hipóteses diagnósticas de internação na UTI Cardiológica entre os pacientes estudados, nos meses entre janeiro e março de 2011 - São Paulo - 2011

Tabela 7 - Distribuição das operadoras de saúde entre os pacientes do estudo, nos meses entre janeiro e março de 2011 - São Paulo 2011 .38

Tabela 8 - Demonstrativo das atividades de enfermagem realizadas, nos meses entre janeiro e março de 2011 - São Paulo 2011

Tabela 9 - Faturamento médio gerado, com base na prescrição de enfermagem e prescrição médica, por paciente, nos meses entre janeiro e março de 2011 - São Paulo - 2011 
Tabela 10 - Percentual médio do faturamento gerado com base na prescrição de enfermagem e médica, nos meses entre janeiro e março de 2011 - São Paulo - 2011

Tabela 11 - Faturamento médio gerado a partir das taxas de enfermagem e de materiais utilizados, com base na prescrição de enfermagem, nos meses entre janeiro e março de 2011 - São Paulo 2011 .56

Tabela 12 - Projeção de faturamento médio por paciente, para os meses entre janeiro e março de 2011 e para 1 ano- São Paulo 2011. .57

Tabela 13 - Demonstrativo da estimativa média de perda de faturamento, nos meses entre janeiro e março de 2011 - São Paulo 2011 .59

Tabela 14 - Projeção de perda média estimada de faturamento para os meses entre janeiro e março de 2011 e para 1 ano de faturamento - São Paulo - 2011 .62

Tabela 15 - Projeção de faturamento médio sem perda monetária, por paciente, entre os meses de janeiro e março de 2011 e para 1 ano de faturamento - São Paulo - 2011.

Tabela 16 - Comparativo médio dos faturamentos avaliados no estudo em relação as três principais operadoras de plano de assistência à saúde e um grupo de outras operadoras, nos meses entre janeiro e março de 2011 - São Paulo - 2011 .65

Tabela 17 - Comparações múltiplas entre as três principais operadoras de saúde e um grupo de outras operadoras, para a amostra estudada, nos meses entre janeiro e março de 2011 - São Paulo - 2011 .68 
Tabela 18 - Comparativo entre as 3 maiores e as 3 menores operadoras de saúde, em relação à forma de remuneração ao hospital, para a amostra estudada, nos meses entre janeiro e março de 2011 - São Paulo - 2011...70 


\section{LISTA DE QUADROS}

QUADRO 1 - Protocolo para realização do estudo de caso....................18 


\section{SUMÁRIO}

1 INTRODUÇÃO

1.1. Justificativa do estudo..................................................1

1.2. A Enfermagem e o processo de faturamento dos hospitais

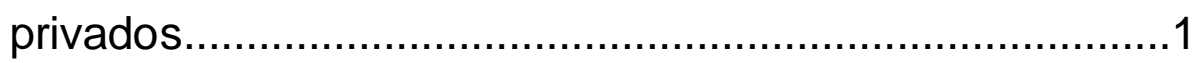

1.3. Definições operacionais para o estudo..............................12

2 QUESTÕES DA PESQUISA..........................................15

3 OBJETIVOS ...................................................................16

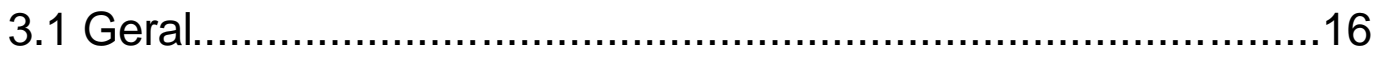

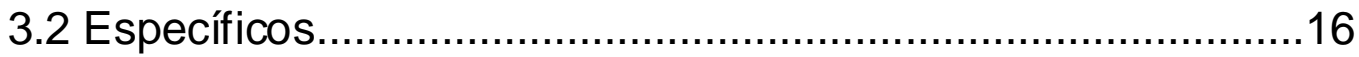

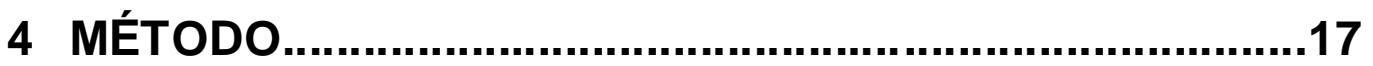

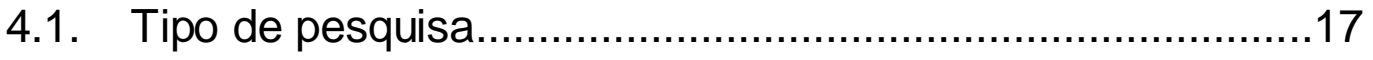

4.2. Protocolo para realização do estudo de caso.......................17

4.3 Unidade de análise.....................................................19

4.3.1Descrição do local de estudo ...............................................19

4.3.2 Processo de faturamento do Hospital em estudo..................20

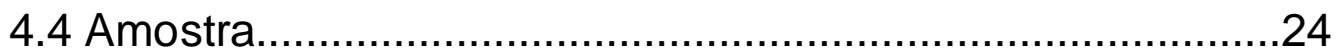

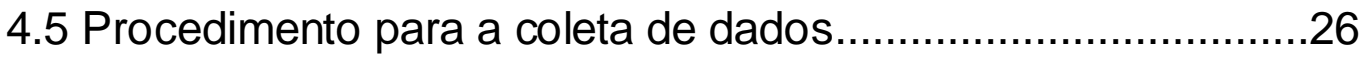

4.6 Procedimentos para análise e tratamento dos dados........................29

4.7 Aspectos éticos da

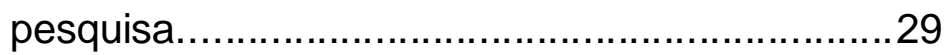

5 APRESENTAÇÃO E DISCUSSÃO DOS RESULTADOS....30

5.1 Caracterização da amostra do estudo................................31 
5.2 Faturamento gerado pelos procedimentos de

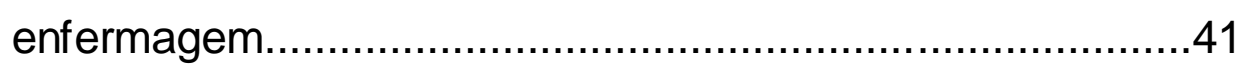

5.3 Projeção do faturamento gerado pela enfermagem..............57

5.4 Estimativa de perda de faturamento ...................................59

5.5 Comparações de faturamento entre as variáveis..................64

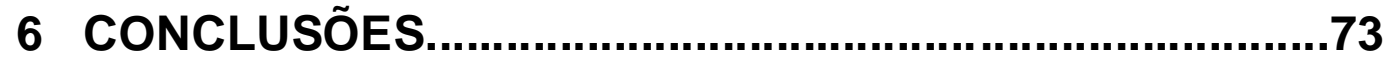

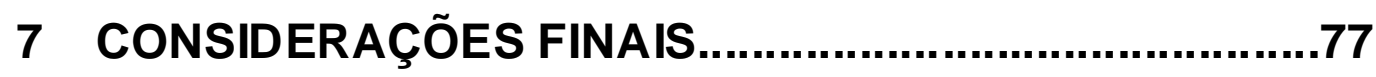

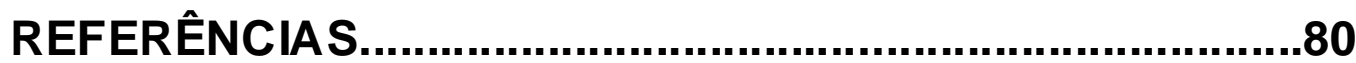

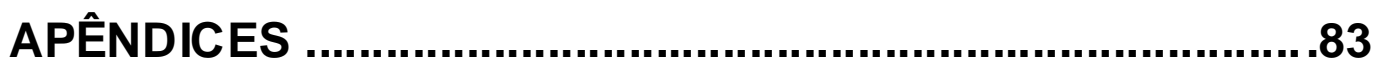

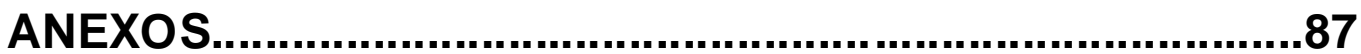




\section{INTRODUÇÃO}

\subsection{JUSTIFICATIVA DO ESTUDO}

O interesse em pesquisar a contribuição da enfermagem para o faturamento de um hospital advém da experiência da autora deste estudo na área de auditoria contábil e central de autorizações de internações e procedimentos em um hospital privado, entre os anos de 2006 e 2009. Nesse período, observou-se um grande volume de procedimentos realizados pela enfermagem agregado à conta dos pacientes, cujo valor monetário não era contabilizado separadamente e, assim, seu retorno financeiro não era conhecido. Ao trocar informações com colegas de outros hospitais, que exerciam a mesma função, os relatos eram semelhantes.

Outro aspecto observado, ao manusear os prontuários contábeis dos pacientes nas instituições hospitalares, foi a falta de cobrança de vários procedimentos realizados pela enfermagem.

Existem procedimentos executados, frequentemente, como passagem de sonda nasoenteral e instalação de inalação que não são contabilizados, cujos materiais e tempo de pessoal consumidos em sua realização entram na composição dos custos das unidades onde são realizados e diluem-se na diária dos pacientes.

Outros procedimentos são faturados para algumas operadoras de plano de assistência à saúde, mas algumas pagam somente os materiais utilizados e outras, além dos materiais, pagam taxas referentes à mão de obra. Isto se deve aos acordos comerciais assinados com as fontes pagadoras - as operadoras de plano de assistência à saúde.

Um dos fatores que tem corroborado para a falta de cobrança relacionada às atividades realizadas pela enfermagem, é a ausência do profissional enfermeiro no setor Comercial das instituições hospitalares e/ou operadoras de planos de assistência à saúde; pois, quem elabora os 
contratos entre prestadores de saúde e convênios, não conhece os procedimentos de enfermagem que são realizados e, portanto, os hospitais deixam de receber por determinadas atividades.

Diante desse cenário, há perda financeira aos hospitais e também ao serviço de enfermagem, que é apontado como um dos serviços de maior custo dentro das organizações, não conhece sua participação no retorno financeiro e pode enfrentar dificuldades na obtenção e manutenção dos recursos necessários para um atendimento seguro.

Para aumentar o faturamento e minimizar as perdas, as organizações hospitalares têm criado serviços de auditoria contábil. Essa área de auditoria interna tem crescido cada vez mais, e suas funções são exercidas, em sua maioria, por enfermeiros, atuando na análise dos prontuários, como controlador, corretor das inconformidades encontradas, negociador com as operadoras de saúde e agente no processo de recurso de glosas apresentadas pelos convênios, visando ao aumento do faturamento hospitalar.

Nesse contexto, o interesse desta pesquisa é descrever e quantificar as atividades de enfermagem realizadas e registradas no prontuário dos pacientes e identificar quais foram contempladas nas contas hospitalares de uma Unidade de Terapia Intensiva (UTI), verificando o quanto (financeiramente) as ações de enfermagem contribuem para o faturamento da UTI de um hospital de grande porte da cidade de São Paulo. Foi também proposto estimar as perdas no faturamento relacionadas às atividades realizadas pela enfermagem e que não são contabilizadas.

A UTI foi escolhida para o desenvolvimento do presente estudo, em razão da grande quantidade e complexidade de procedimentos e ações de enfermagem ali executadas, sendo apontada com o centro cirúrgico como os setores com maiores gastos de recursos, mas também como os que mais contribuem para o faturamento das organizações. 


\subsection{A ENFERMAGEM E O PROCESSO DE FATURAMENTO DOS HOSPITAIS PRIVADOS}

Nos últimos anos, os hospitais privados brasileiros vêm vivenciando grandes dificuldades financeiras por não poderem repassar seus aumentos de custos aos preços cobrados às operadoras de saúde, sobretudo pela "alta competitividade do mercado, à pressão da sociedade e dos planos de saúde, e a um certo controle de preços do governo." Dessa forma, os hospitais têm sido obrigados a voltar sua atenção para o controle de custos, para não ficarem deficitários ${ }^{1-2}$.

Assim, como forma de garantir o faturamento sem perder a qualidade da assistência prestada, o gerenciamento de custos tem sido implementado no campo da saúde, como forma de assegurar a rentabilidade das organizações.

O faturamento é definido como o "conjunto de recebimentos expressos em unidades monetárias, obtidos por uma empresa com a venda de bens ou serviços em determinado período". 3

Já a rentabilidade, é o "grau de rendimento, ou seja, de retorno financeiro proporcionado por determinado investimento". ${ }^{3}$

Conforme Falk ${ }^{4}$, o gerenciamento de custos é uma "ferramenta gerencial para a melhoria do desempenho da organização em termos de fornecer informação necessária para a tomada de decisões objetivas, visando à contenção de gastos ou ao aumento na receita, ou ambos".

Neste aspecto, como o enfermeiro está inserido em todas as áreas da assistência e "possui domínio dos conhecimentos específicos da assistência, coordena todas as atividades realizadas aos pacientes e aloca recursos para seu desenvolvimento" é, portanto, o profissional com maior conhecimento dos processos de trabalho dentro das instituições hospitalares ${ }^{5}$ e, por isso, tem sido cada vez mais requisitado nas decisões financeiras dos serviços de saúde. ${ }^{6}$ Autores ${ }^{7}$ afirmam que nenhum administrador possui o conhecimento 
que o enfermeiro tem sobre administração hospitalar, embora estes precisem aprimorar seus conhecimentos sobre finanças e marketing.

Em 1993, o Conselho Internacional de Enfermeiras (CIE) ${ }^{8}$, lançou um documento denominado "A qualidade, os custos e a enfermagem", em que expõe a necessidade dos enfermeiros levarem em conta os custos hospitalares para avaliarem os resultados de suas ações, em razão das pressões econômicas mundiais crescentes. Ainda, conforme o CIE, "finanças" é outra área de conhecimento das enfermeiras, que devem demonstrar os custos e a rentabilidade de sua assistência para serem capazes de argumentar na luta para obtenção dos recursos necessários à prestação de uma assistência segura. ${ }^{8}$

A literatura brasileira carece de estudos sobre o gerenciamento de custos em enfermagem e mais ainda a respeito do retorno financeiro da assistência de enfermagem aos serviços de saúde. Assim, embora a equipe de enfermagem realize várias atividades no cuidado ao paciente, não sabemos hoje seu valor financeiro e o quanto do faturamento de um hospital está relacionado à assistência de enfermagem.

A enfermagem ainda é considerada como um "custo" para os serviços de saúde, embora também seja geradora de receita; alguns autores afirmam que pode ser responsável por $40 \%$ a $50 \%$ de todo o faturamento de um hospital. ${ }^{7}$

Autores americanos afirmam que, nos Estados Unidos da América (EUA), a enfermagem também é vista mais como um "custo" do que uma "renda" dentro dos hospitais, estando em constante ameaça quando se pretende diminuir custos. Ratificam ainda que as instituições não são diretamente remuneradas pelo cuidado de enfermagem, como ocorre com os serviços médicos. ${ }^{9}$

Historicamente, o custo do serviço de enfermagem permaneceu embutido no cálculo do custo do paciente-dia. Este fato dificulta tanto identificar a utilização de recursos de enfermagem pelos diversos setores do 
hospital como determinar a contribuição da enfermagem para a receita total do hospital. ${ }^{10}$

Em um estudo desenvolvido no Brasil, por Zunta $(2006)^{11}$, verificou-se que $15,1 \%$ do faturamento total de uma UTI adulto eram oriundos da assistência de enfermagem, e 11,3\% tinham como origem a prescrição de enfermagem e 3,8\% eram provenientes da prescrição médica. Esse faturamento foi proveniente de apenas 24 procedimentos realizados pela enfermagem. ${ }^{11}$

É imprescindível que o enfermeiro realize o gerenciamento dos custos associados à assistência de enfermagem, como forma de demonstrar sua participação no faturamento total do hospital e sua rentabilidade. ${ }^{11}$ Mas, para que isso seja possível, é necessária a criação de um sistema de custos para a área da enfermagem, pois sabidamente existem atividades que são exercidas pela equipe de enfermagem e que não são revertidas como faturamento da área e, às vezes, para piorar esse quadro, estas atividades são pagas aos médicos, conforme se constatou em um estudo realizado nos EUA. $^{12}$

Conhecendo os custos do trabalho da equipe de enfermagem, o enfermeiro pode se instrumentalizar para tomar decisões que visem à otimização dos recursos disponíveis, sem que o controle sobre os custos possa diminuir a qualidade da assistência prestada ${ }^{13}$, já que o melhor gerenciamento dos custos hospitalares está intimamente relacionado à melhoria da eficácia dos processos organizacionais. ${ }^{11}$

O conhecimento do enfermeiro sobre custos é fundamental em sua prática administrativa. No entanto, estudos realizados no Brasil revelam que os gestores em enfermagem têm baixo nível de conhecimento em custos, sobretudo no que se refere aos conceitos fundamentais e sobre como utilizálos em sua prática profissional ${ }^{14}$ e que, quando estes gestores têm acesso a informações acerca de custos, não se sentem preparados para usá-las. ${ }^{15}$

Um estudo brasileiro realizado em 2011 evidenciou que apenas $35,3 \%$ dos enfermeiros gestores entrevistados tinham conhecimentos sobre 
conceitos fundamentais em custos ${ }^{5}$. Isto demonstra que, embora o enfermeiro tenha assumido um papel de extrema importância no contexto hospitalar, ainda precisa aprimorar seus conhecimentos em gestão de custos, como forma de melhorar a alocação de recursos e otimização dos resultados. ${ }^{5}$

Os hospitais têm requisitado o enfermeiro também para atuar na área de auditoria contábil, pois, se por um lado as organizações de saúde têm tentado conhecer e controlar seus custos; por outro, têm utilizado ferramentas gerenciais para aumentar seus faturamentos. A auditoria contábil realiza a revisão dos processos institucionais para minimizar os erros e garantir que as operadoras de planos de assistência à saúde paguem pelo atendimento prestado ao hospital.

A finalidade da auditoria contábil é "conferir e controlar o faturamento enviado para os planos de saúde, verificar exames e procedimentos realizados, efetuar visitas de rotina a pacientes internados, cruzando as informações recebidas com as que constam no prontuário do paciente. Visa, também a investigar a propriedade dos gastos e processos de pagamentos, analisar as estatísticas, indicadores hospitalares e específicos da organização, conferir os sistemas de faturamentos das contas médicas e, ainda, elaborar processos de glosas contratuais e administrativas". ${ }^{16}$

O processo de auditoria é "uma avaliação sistemática e formal de uma atividade realizada por pessoas não envolvidas diretamente em sua execução, a fim de se determinar se a atividade está de acordo com os objetivos propostos". ${ }^{17}$

Atualmente, a auditoria visa a realizar uma avaliação sistemática da qualidade da assistência de enfermagem, pela leitura das anotações de enfermagem no prontuário do paciente e/ou das próprias condições deste. ${ }^{18}$

A auditoria está mais voltada à visão contábil-financeira dos processos assistenciais, tendo como meta a sustentação econômica das organizações hospitalares, e estas, muitas vezes, têm em suas estruturas, unidades de controladoria. Assim, os enfermeiros participam da auditoria 
contábil das organizações hospitalares, atuando como controller, visando a identificar pagamentos indevidos presentes na conta hospitalar. $O$ enfermeiro auditor tem como objetivo máximo de sua atuação comprovar o pagamento das contas hospitalares, rever glosas efetuadas pelas operadoras de saúde e realizar negociações com os enfermeiros auditores dos planos de saúde. ${ }^{19}$

Tanto os hospitais como as operadoras/planos de saúde devem possuir enfermeiros na elaboração de contratos e tabelas ${ }^{20}$, pois 0 enfermeiro é o profissional que melhor conhece os procedimentos, rotinas, materiais e medicamentos envolvidos no cuidado ao paciente dentro de um hospital; na literatura nacional, não existem estudos sobre a participação do enfermeiro na área Comercial dos hospitais e/ou operadoras/planos de saúde, refletindo a lacuna que existe no mercado de trabalho.

A repercussão é a existência de contratos e tabelas com falhas de cobrança/pagamentos nos hospitais, cuja conta hospitalar nem sempre contém taxas sobre todos os procedimentos realizados e materiais utilizados pela equipe de saúde, com perda monetária importante às instituições de saúde.

Atividades como administração de medicamentos, realização de banho, sondagens, etc., podem estar incluídas na cobrança da diária hospitalar ou constituírem taxas com pagamentos vinculados à realização ou não dos procedimentos; a forma de remuneração por tais cuidados prestados depende, sempre, do contrato comercial/financeiro acordado entre as organizações hospitalares e as operadoras de saúde.

No mercado de saúde, existem várias formas de remuneração entre a operadora de saúde e o hospital. O pagamento por meio de "conta aberta" ocorre para aqueles casos assistenciais em que há baixa previsibilidade e alta variabilidade de desfecho, sendo difícil a cobrança mediante padronização de procedimentos e materiais/medicamentos. Assim, a conta será composta por todos os itens consumidos durante a internação do 
paciente (materiais, medicamentos, diárias, taxas, honorários médicos e gases medicinais). ${ }^{21}$

O pagamento por "diária compactada" prevê a elaboração de uma tabela para diárias e taxas com menor número de itens de consumo, como forma de simplificar a cobrança e facilitar a emissão dos prontuários contábeis pelos hospitais, oferecendo maior agilidade às operadoras de saúde na auditoria dessas contas.

Para aqueles processos assistenciais com alta previsibilidade e/ou baixa variabilidade de desfecho, é possível a padronização de cobrança de um maior número de insumos e serviços, optando-se, neste caso, pelo pagamento mediante a cobrança de "diária global", que representa o pagamento único por um conjunto de serviços hospitalares (diárias, taxas de enfermagem, honorários médicos para setores fechados, taxas sobre utilização de equipamentos, gases medicinais). Neste tipo de remuneração, itens como materiais, medicamentos, órteses, próteses e materiais especiais, serviços auxiliares de diagnóstico e tratamento são cobrados na forma de "conta aberta". A remuneração por meio de diária global diminui ainda o índice de glosas, uma vez que a maior parte dos insumos hospitalares está incluída nessa diária. Existem contratos de diárias globais para os setores de UTI, centro cirúrgico, hemodinâmica e centro obstétrico.

A remuneração pelos procedimentos de preços previsíveis, os chamados "pacotes" oferecem uma alternativa de pagamento pelas operadoras de saúde aos hospitais por aqueles processos assistenciais de baixa complexidade, em especial cirurgias ambulatoriais e internações de curta permanência. $\mathrm{O}$ preço preestabelecido por procedimento simplifica a cobrança e reduz os custos na confecção do prontuário contábil. Para a elaboração dos "pacotes", é necessária uma análise retrospectiva dos valores médios das contas hospitalares, com atenção especial em relação aos materiais, medicamentos e taxas presentes nessas contas. ${ }^{22}$

O que ocorre nos hospitais, geralmente, é que no processo de elaboração das contas hospitalares, a análise dos prontuários clínicos é feita com base nas anotações de enfermagem e, muitas vezes, esta atividade é realizada por auxiliares administrativos, que não possuem conhecimento 
técnico-científico para avaliar se os procedimentos de enfermagem descritos são condizentes com os materiais presentes na fatura hospitalar. Assim, pode ocorrer uma discrepância entre o que é realizado, o que é anotado e o que é efetivamente cobrado do convênio. Por outro lado, embora a anotação de enfermagem esteja clara e completa e os materiais devidamente cobrados na conta hospitalar, por não constar, em contrato comercial firmado entre o hospital e a operadora de saúde, taxa relacionada ao procedimento em si, o pagamento pela mão de obra não pode ser faturado.

No estudo realizado por Zunta et al. $(2006)^{23}$, em um hospital brasileiro, constatou-se que a equipe de enfermagem possuía várias falhas relacionadas à anotação, como a ocorrência de registros incompletos, falta de registro de materiais na planilha de cobrança, falta de checagem das prescrições médica e de enfermagem, etc. Após um treinamento sobre custos e cobrança de materiais/medicamentos, houve uma significativa redução das divergências e, consequentemente, redução das glosas hospitalares. ${ }^{23}$ Isto só reforça que a anotação de enfermagem é imprescindível, tanto para verificação da qualidade do cuidado prestado como para garantir que todos os procedimentos realizados sejam registrados e possam, posteriormente, ser devidamente cobrados dos convênios.

As anotações de enfermagem fazem parte do prontuário do paciente e constituem responsabilidade legal da enfermagem, e são com base nas informações obtidas por meio das anotações da equipe de enfermagem que grande parte dos materiais, medicamentos, procedimentos e outros serviços podem ser cobrados na conta hospitalar do paciente e apresentados à operadora de saúde. ${ }^{11,24-25}$

Vários estudos têm evidenciado as falhas das anotações de enfermagem, e isto acarreta perda de faturamento aos hospitais.

Um estudo conduzido em um hospital universitário do Estado do Paraná evidenciou falhas das anotações de enfermagem, pois não havia registros sobre alguns procedimentos, como troca de curativos, oxigenioterapia, passagens de sondas e punções venosas. ${ }^{26}$ 
Outro estudo realizado em um hospital universitário do Estado de São Paulo avaliou, com base na auditoria dos prontuários dos pacientes, a qualidade dos registros de enfermagem e os resultados mostraram que $26,7 \%$ dos prontuários foram considerados ruins, $64,6 \%$ eram regulares e $8,7 \%$, bons. ${ }^{27}$

Quando não há registro ou há registros incompletos, itens da conta hospitalar podem receber glosa das operadoras/convênios de saúde, com perda significativa para o faturamento dos hospitais.

Entende-se por glosa, como o "cancelamento ou recusa, parcial ou total, de orçamento, conta, verba por serem considerados ilegais ou indevidos" ${ }^{17}$, ou seja, são itens que o auditor da operadora de plano de assistência à saúde recusa-se a pagar.

As glosas podem ser classificadas como administrativas ou técnicas; as administrativas ocorrem por falha operacional no momento da cobrança, "falha de interação entre o plano de saúde e o prestador de serviço ou, ainda, falha no momento da análise da conta do prestador" ${ }^{17}$; as glosas técnicas referem-se à apresentação dos valores dos materiais e medicamentos utilizados.

A glosa reflete perda de faturamento para o hospital e pode ser revertida, posteriormente, baseada em recurso de glosas, a fim de recuperar a perda econômica sofrida. ${ }^{17}$

No estudo conduzido por Rodrigues et al. ${ }^{17}$, verificou-se que a maior parte das glosas sofridas pela instituição hospitalar estudada estavam relacionadas a materiais e medicamentos (55\% e $31,7 \%$ respectivamente). O recurso de glosas baseou-se na apresentação das anotações de enfermagem e apresentação das prescrições médica e de enfermagem checadas, com reversão de $89,2 \%$ das glosas sobre materiais e $30,6 \%$ de reversão das glosas referentes a medicamentos, ratificando mais uma vez a importância das anotações de enfermagem para o faturamento de um hospital. ${ }^{17}$ 
Assim, analisando todos os fatores acima mencionados, e, levando em consideração que, embora a enfermagem execute várias atividades em sua prática diária, existem poucos estudos que evidenciam o quanto a assistência prestada em uma UTI contribui para o faturamento dessa unidade e para o hospital de um modo geral. Conforme estudo europeu, as admissões das UTls correspondem a $5 \%$ do total de admissões realizadas em um hospital, mas esses pacientes consomem cerca de $20 \%$ de todos os recursos disponíveis. ${ }^{28}$ Pretende-se, com este estudo, descrever, quantificar e analisar como as atividades executadas pela equipe de enfermagem de uma UTI Cardiológica impactam financeiramente nas contas hospitalares de um hospital filantrópico.

Tem-se como finalidade, com esta pesquisa, valorar o trabalho de enfermagem, além de verificar e analisar o valor financeiro que os cuidados de enfermagem prestados contribuem para o faturamento de uma UTI, descrevendo o valor monetário real dessas atividades e o quanto elas representam, financeiramente, no fechamento da conta hospitalar. Além disso, buscou-se descrever quais atividades de enfermagem executadas não recebem pagamento em conta hospitalar e estimar a perda média de faturamento para a UTI e ao hospital. 


\subsection{DEFINIÇÕES OPERACIONAIS PARA O ESTUDO}

É imprescindível aqui que apresentemos alguns conceitos básicos de Contabilidade e Auditoria para melhor compreendermos o assunto deste estudo.

Custo: "É o gasto relativo a bem ou serviço utilizado na produção de outros bens e serviços". ${ }^{29}$

Faturamento: "Conjunto de recebimentos expressos em unidades monetárias, obtidos por uma empresa com a venda de bens ou serviços em determinado período", ou ainda, "é o número de unidades de bens ou serviços vendidos multiplicados pelo preço de venda unitário". ${ }^{3}$

Fatura: "É um documento que contém todos os serviços prestados pelo hospital utilizados pelo paciente. Depois da alta do paciente, é emitida a fatura do que foi utilizado pelo cliente e encaminhada ao convênio, para que seja efetuado o pagamento". ${ }^{11}$

Preço: "Em sentido mais usual e restrito, representa a proporção de dinheiro que se dá em troca de determinada mercadoria, constituindo, portanto, a expressão monetária de um bem ou serviço". ${ }^{3}$

Receita: "É o recebimento das vendas, acrescidos de eventuais rendimentos de aplicações financeiras". ${ }^{3}$

Prontuário clínico (ou prontuário do paciente): é um conjunto de documentos padronizados, ordenados

e concisos, com 
a finalidade de registrar todas as informações referentes aos cuidados prestados pelos profissionais da saúde (médicos, enfermeiros, fisioterapeutas, psicólogos, etc.) ao paciente..$^{30}$

Prontuário financeiro (ou contábil): é a conta hospitalar propriamente dita de um paciente, que contém todas as diárias, taxas, materiais, medicamentos, honorários médicos e procedimentos.

Conta "suja": é um termo utilizado nos hospitais, na área de auditoria contábil; é a primeira conta emitida pelo setor de faturamento; contém todos os materiais e medicamentos consumidos durante a internação do paciente; essa conta será analisada pelo auditor interno (geralmente, é um enfermeiro), para possíveis correções e ajustes. Após as correções devidas, a conta é reimpressa e apresentada aos auditores interno e externo. A conta será negociada entre os auditores, para acertarem sobre pagamento dos materiais/medicamentos/taxas/diárias/procedimentos/honorários médicos.

Conta "limpa": também é um termo utilizado em auditoria contábil; é a conta que já foi analisada pelos auditores interno e externo e contém o valor final que será pago, pela operadora de plano de assistência à saúde, ao hospital.

Glosa: cancelamento ou recusa, parcial ou total, de orçamento, conta, verba por serem considerados ilegais ou indevidos. É emitida pelo auditor da operadora de plano de assistência à saúde. ${ }^{17}$

Recurso de glosa: é a apresentação, pelo hospital, de justificativas para a reversão das glosas recebidas da operadora de plano de assistência à saúde. ${ }^{17}$ 
Diária hospitalar: "É a permanência de um paciente por um período indivisível de até 24 horas em uma instituição hospitalar. A definição de hora início/fim do período é de competência da instituição hospitalar". ${ }^{31}$

Diária hospitalar compacta: é a cobrança da permanência do paciente dentro da instituição de saúde, acrescida de materiais/medicamentos/taxas/diárias/procedimentos constantes em contrato comercial.

Conta pacote: é o valor "fechado", constante em contrato comercial, sobre determinado procedimento cirúrgico; inclui número de diárias (UTI/apartamento), procedimentos, materiais, medicamentos e taxas já embutidas no valor total a ser pago. 


\section{QUESTÕES DA PESQUISA}

Qual é o montante financeiro decorrente das atividades realizadas pela enfermagem em uma UTI Cardiológica de um hospital filantrópico, no fechamento das contas hospitalares?

Quais são o tipo e a quantidade de atividades de enfermagem realizadas e não contabilizadas nas contas hospitalares dos pacientes de uma UTI?

Quanto é a perda financeira resultante do não pagamento das atividades de enfermagem realizadas? 


\section{OBJETIVOS}

\subsection{GERAL}

- Calcular o faturamento gerado pelos procedimentos de enfermagem, em uma UTI Cardiológica de um hospital geral, filantrópico, na cidade de São Paulo, entre os meses de janeiro e março de 2011.

\subsection{ESPECÍFICOS}

- Levantar os procedimentos de enfermagem realizados em uma UTI Cardiológica de um hospital filantrópico;

- Identificar os procedimentos de enfermagem que constam na conta do paciente e que são remunerados pelas operadoras de plano de assistência à saúde;

- Calcular o montante financeiro gerado pelas atividades de enfermagem pagas pelas operadoras de plano de assistência à saúde ao hospital;

- Calcular a porcentagem do faturamento gerado pela enfermagem em relação ao faturamento da UTI nos meses estudados;

- Levantar as ações de enfermagem que são realizadas, mas que não recebem taxação (pagamento) e

- Estimar a perda monetária do hospital relacionada às atividades de enfermagem que não recebem pagamento das operadoras de saúde. 


\section{MÉTODO}

\subsection{TIPO DE PESQUISA}

Trata-se um estudo de caso exploratório, descritivo, com abordagem quantitativa.

O estudo de caso é uma pesquisa empírica que "investiga um fenômeno contemporâneo em profundidade e em seu contexto de vida real, especialmente, quando os limites entre o fenômeno e o contexto não são claramente evidentes". ${ }^{32}$

Como método de pesquisa, o estudo de caso "envolve uma análise completa e detalhada de um indivíduo, grupo ou de outra unidade social". ${ }^{33}$

\subsection{PROTOCOLO PARA REALIZAÇÃO DO ESTUDO DE CASO}

O protocolo de estudo de caso contém não só o instrumento para a coleta dos dados, como também as regras a serem seguidas ao se utilizá-lo.

Visa a aumentar a confiabilidade da pesquisa e orientar o pesquisador durante a realização da coleta dos dados e tem por objetivos apresentar as etapas a serem seguidas durante a pesquisa científica, bem como as finalidades de cada etapa com as respectivas atividades a serem executadas. 32 
Quadro 1 - Protocolo para realização do estudo de caso

\begin{tabular}{|c|c|c|}
\hline ETAPA & OBJETIVOS & ATIVIDADES \\
\hline $\begin{array}{c}\text { Revisão } \\
\text { bibliográfica }\end{array}$ & $\begin{array}{l}\text { Levantar a produção } \\
\text { científica relacionada ao } \\
\text { tema. }\end{array}$ & $\begin{array}{c}\text { Pesquisa bibliográfica em banco de } \\
\text { dados: Medline, LILACS, Pubmed } \\
\text { Central. }\end{array}$ \\
\hline $\begin{array}{l}\text { Levantamento de } \\
\text { hipóteses. }\end{array}$ & $\begin{array}{l}\text { Descrever as questões de } \\
\text { investigação da pesquisa. }\end{array}$ & $\begin{array}{l}\text { Identificar e descrever os objetivos } \\
\text { gerais e específicos do estudo de } \\
\text { caso. }\end{array}$ \\
\hline Planejamento & $\begin{array}{l}\text { Elaborar protocolo de coleta } \\
\text { de dados. }\end{array}$ & $\begin{array}{l}\text { Definir as etapas da pesquisa, } \\
\text { incluindo a coleta e análise dos } \\
\text { dados. }\end{array}$ \\
\hline Coleta de dados & $\begin{array}{l}\text { Coletar os dados necessários } \\
\text { para responder às questões } \\
\text { do estudo de caso. }\end{array}$ & $\begin{array}{l}\text { Descrever o processo de } \\
\text { faturamento do hospital. } \\
\text { Confeccionar planilhas no Excel, } \\
\text { para registro dos dados coletados. } \\
\text { Levantar prontuários clínicos e } \\
\text { contábeis dos pacientes } \\
\text { selecionados para a amostra. }\end{array}$ \\
\hline $\begin{array}{l}\text { Análise dos } \\
\text { dados }\end{array}$ & $\begin{array}{c}\text { Analisar as informações } \\
\text { fornecidas pelos prontuários } \\
\text { clínicos e contábeis. }\end{array}$ & $\begin{array}{l}\text { Agrupar os dados. } \\
\text { Submeter os dados à análise } \\
\text { estatística. } \\
\text { Organizar os dados em variáveis } \\
\text { quantitativas e qualitativas. } \\
\text { Realizar a triangulação dos dados. }\end{array}$ \\
\hline Conclusão & $\begin{array}{l}\text { Apresentar conclusões sobre } \\
\text { o faturamento gerado pela } \\
\text { enfermagem na UTI. }\end{array}$ & $\begin{array}{l}\text { Sintetizar os dados, realizando } \\
\text { considerações finais e } \\
\text { recomendações para futuros } \\
\text { estudos. }\end{array}$ \\
\hline
\end{tabular}

Fonte: Adaptado de Yin, 2010. ${ }^{32}$ 


\subsection{UNIDADE DE ANÁLISE}

\subsubsection{Descrição do local do estudo}

O estudo foi desenvolvido na UTI Cardiológica de um hospital geral filantrópico, de grande porte, com 319 leitos, na cidade de São Paulo.

O hospital pertence a uma associação religiosa e filantrópica. A gestão da Instituição vem mudando nos últimos 5 anos e embora a associação religiosa ainda tenha forte poder de decisão, as diretorias administrativa e executiva do hospital estão hoje sob a responsabilidade de profissionais contratados.

Esta mudança teve por objetivo inserir a instituição comercialmente no mercado de assistência à saúde, com um investimento maior em campanhas publicitárias, como forma de divulgar o nome do hospital junto à população de uma forma geral.

Concomitantemente, ocorreu também a substituição dos gestores das áreas de atendimento, enfermagem, auditoria, diretoria de recursos humanos e diretoria comercial. Com isso, algumas áreas foram reformuladas, como os setores de Auditoria e Comercial.

O setor de Auditoria especificamente passou por um novo dimensionamento, sobretudo em relação aos profissionais operacionais, com a substituição destes por enfermeiros que já atuavam na Instituição, como enfermeiros assistenciais e que se destacavam no conhecimento dos processos de trabalho da organização.

O Hospital possui três UTIs que atendem à clientela adulta, tanto clínicos como cirúrgicos. A UTI Cardiológica do estudo conta com 16 leitos e possui uma média de 113 internações mensais, com uma taxa média de ocupação de $91,5 \%$.

A UTI foi a área de estudo escolhida por ser uma grande fonte geradora de custos e receitas dentro do campo de estudo. 
O quadro de pessoal de enfermagem da UTI Cardiológica é composto por uma coordenadora de enfermagem, duas supervisoras de enfermagem, 16 enfermeiros e 44 técnicos de enfermagem, não possuindo mais em seu quadro auxiliares de enfermagem.

A equipe multiprofissional da UTI é constituída por dois fisioterapeutas e dois médicos intensivistas, além da equipe de apoio (um farmacêutico clínico, uma psicóloga e uma nutricionista).

Os profissionais de enfermagem prestam cuidados integrais aos pacientes, e a organização da assistência de enfermagem baseia-se no modelo Primary Nursing, no qual um enfermeiro é responsável por um grupo de pacientes, desde a internação até sua alta da unidade, cabendo a este profissional a elaboração do plano de cuidados para estes clientes. ${ }^{34}$

A documentação referente à Sistematização da Assistência de Enfermagem (SAE) encontra-se implantada na UTI de forma eletrônica, por meio de um sistema de informação hospitalar. Os procedimentos de enfermagem são padronizados e constam em prescrição de enfermagem, sendo checados, conforme a realização pelos técnicos de enfermagem.

\subsubsection{Processo de faturamento do Hospital em estudo}

O prontuário contábil do paciente é também chamado de conta hospitalar; esta inicia-se com a internação do paciente e é finalizada com a alta hospitalar.

A conta hospitalar é composta pelas diárias (correspondente ao número de dias em que este paciente permaneceu internado no hospital, e, diariamente, às $12 \mathrm{~h}$, é acrescentada uma nova diária); além das diárias, a conta possui ainda a cobrança referente às diferentes taxas (gases, procedimentos médicos, procedimentos de enfermagem, procedimentos de fisioterapia), materiais e medicamentos utilizados na assistência ao paciente. 
O Hospital é dividido por centros de custos, portanto, cada unidade de serviço possui um centro de custo próprio. Na emissão da conta hospitalar, as diárias, taxas, materiais, medicamentos, honorários médicos, procedimentos e gases são cobrados de acordo com o centro de custo da unidade de internação em que o paciente esteve internado; caso o paciente tenha sido admitido em unidades de internação diferentes (clínica médica, UTI ou hemodinâmica, por exemplo), a cobrança dos itens será feita discriminadamente, por centro de custo.

Durante a internação do paciente na UTI Cardiológica, é realizada auditoria diariamente de seu prontuário contábil pelo auxiliar de faturamento da UTI. Este, embora pertença ao quadro de pessoal do setor de Faturamento, encontra-se locado fisicamente na UTI.

Ele realiza a conferência de todo o prontuário clinico e confirma se as prescrições médicas e de enfermagem estão checadas, se o que está sendo cobrado corresponde às anotações de enfermagem, e se estas são claras e completas; o auxiliar de faturamento também confere se as identificações dos profissionais (médicos, enfermeiros, técnicos de enfermagem, fisioterapeutas) estão corretas.

Quando o auxiliar de faturamento detecta alguma imprecisão na informação ou falta de checagem na prescrição médica e/ou de enfermagem, o prontuário contábil e o prontuário clínico são entregues à enfermeira supervisora da UTI, que será responsável pela correção das informações e os devolverá ao auxiliar de faturamento apenas quando a inconsistência for corrigida. Concomitantemente, ela procurará o profissional responsável pela falha e fará uma orientação sobre o erro detectado, para que este não ocorra novamente.

Quando o paciente recebe alta da UTI Cardiológica, a conta hospitalar referente aos dias de internação do paciente na UTI é encerrada pelo auxiliar de faturamento, e este tem prazo de 24 horas para envio dos prontuários clínico e contábil para a Auditoria. É realizada a impressão do prontuário contábil referente aos dias de internação em UTI e é, então, feita 
uma última conferência para verificar se os itens que estão sendo cobrados na conta conferem com o prontuário clínico do paciente, por meio da checagem das prescrições médicas e de enfermagem e das anotações e evoluções de enfermagem.

Depois da finalização desse processo, os prontuários clínico e contábil são enviados para o setor de Auditoria. Após a alta do paciente da UTI, na Auditoria, será realizada uma pré-análise por um auditor, que pode ser enfermeiro ou não, e que fará a leitura do prontuário clínico do paciente e conferirá se todos os procedimentos realizados e anotados estão sendo cobrados no prontuário contábil do paciente; posteriormente, este prontuário contábil será apresentado ao auditor da operadora de plano de assistência à saúde correspondente para análise. Após esse processo, o auditor externo negociará com o auditor interno sobre as possíveis glosas da conta. Esta "negociação" ocorrerá até que haja anuência por ambos os auditores sobre o que será pago pela operadora ao hospital, o que receberá glosa (não sendo, portanto pago pela operadora ao hospital) e os itens que serão enviados à operadora de plano de assistência à saúde como divergência.

A conta que foi analisada pelos auditores interno e externo, recebe 0 nome de "conta suja", pois contém todos os ajustes que foram feitos, mediante a negociação realizada entre os auditores.

Após a conclusão da negociação entre os auditores interno e externo, a conta é entregue a uma auxiliar de faturamento do setor de Auditoria, que fará a "limpeza" da conta in loco, com a retirada dos itens que foram "glosados" pelo auditor externo, com a anuência do auditor interno; permanecerão no prontuário contábil apenas os itens que foram acordados entre os auditores, e estes itens representam o que será efetivamente pago pela operadora de plano de assistência à saúde ao hospital. Esta conta é a chamada "conta limpa".

Os itens que foram glosados pelo auditor externo e que não foram aceitos pelo auditor interno representam as divergências, que não serão pagas pela operadora de plano de assistência à saúde ao hospital e serão 
negociadas posteriormente, por meio do recurso de glosas. Estas divergências também não constam na "conta limpa" e, portanto, não são incluídas na fatura do paciente.

A "conta limpa" é impressa e recebe o carimbo profissional dos auditores interno e externo. $O$ auditor externo preencherá um impresso da própria operadora de plano de assistência à saúde chamado "capeante", que é um resumo sobre todas as contas hospitalares que foram negociadas naquele mês, com a discriminação do nome dos pacientes, os valores totais de cada conta, o valor das divergências e das glosas aceitas. $O$ capeante recebe o carimbo dos auditores interno e externo e uma cópia deste documento é enviada à operadora do plano de assistência à saúde e outra é enviada ao setor de Contas Médicas do hospital, para acompanhamento do pagamento dessas contas hospitalares.

Após o término de negociação e fechamento do capeante, o prontuário clínico é encaminhado ao Setor de Arquivo Médico (SAME) do Hospital, para acondicionamento. A conta limpa que recebeu o carimbo dos auditores interno e externo será entregue ao setor de Contas Médicas.

Após esses trâmites, a documentação referente à conta hospitalar fica anexada ao prontuário contábil do paciente. 


\subsection{AMOSTRA}

Para conformação da amostra, o estudo foi submetido à análise de um profissional estatístico.

Definiu-se pela coleta de dados por 3 meses consecutivos, pois este período poderia apresentar uma variabilidade maior quanto aos tipos de pacientes atendidos.

A metodologia utilizada foi para uma amostra aleatória estratificada e foi considerado um intervalo com $95 \%$ de confiança, podendo haver um erro amostral máximo de $5 \%$.

Para o sorteio da amostra, buscou-se a planilha de controle de ocupação da UTI Cardiológica, que é confeccionada pelo auxiliar administrativo da UTI e que contém todas as admissões da UTI a cada mês.

O processo de encerramento da conta hospitalar, análise dos auditores interno e externo, envio da fatura à operadora de assistência à saúde e efetivo recebimento do pagamento pela operadora é um processo que pode levar de 2 a 3 meses; durante esse período, o prontuário clínico permanece no setor de Auditoria. Assim, os meses de janeiro a março de 2011 foram escolhidos para realização da coleta dos dados pela maior disponibilidade dos prontuários para a autora do estudo, já que a coleta dos dados ocorreu entre os meses de julho e setembro de 2011.

Entre os meses de janeiro e março de 201, houve um total de 319 internações na UTI Cardiológica, com uma média de 113 admissões por mês. A amostra total calculada para 3 meses foi de 168 pacientes, distribuídos da seguinte forma: para cada mês de internação, foram sorteados 35 pacientes clínicos e 21 cirúrgicos, totalizando 168 pacientes.

Nos meses selecionados, foram escolhidos primeiramente os pacientes de número ímpar na planilha de internação até o total de 35 pacientes clínicos e 21 cirúrgicos de cada mês; caso houvesse um número menor de pacientes clínicos e/ou cirúrgicos, era iniciada a escolha dos pacientes de número par na planilha de internação, até que a amostra do 
mês fosse concluída, totalizando 56 pacientes (entre clínicos e cirúrgicos) em cada um dos meses estudados.

Após o sorteio da amostra, a autora do estudo entregou a relação dos prontuários clínicos selecionados à gestora do SAME do hospital, para que fosse realizado um levantamento da localização dos prontuários clínicos.

O Hospital não dispõe de espaço físico suficiente para acondicionamento dos prontuários clínicos; assim, prontuários de pacientes que receberam alta hospitalar há mais de 3 meses e que tenham o processo de faturamento finalizado pela Auditoria, são enviados para uma empresa terceirizada de arquivamento de prontuários.

Aqueles prontuários clínicos selecionados para a amostra que se encontravam na empresa terceirizada de armazenamento foram solicitados à empresa pelo SAME, via email, para que retornassem ao hospital.

Alguns prontuários clínicos selecionados não puderam ser disponibilizados por estarem em uso na Auditoria. Assim, foi realizado um segundo sorteio, para que o número calculado da amostra pudesse ser alcançado.

Para a realização do segundo sorteio, foi utilizada novamente a planilha de ocupação da UTI Cardiológica. Foram escolhidos os pacientes de número ímpar na planilha de internação, começando pelo final da planilha, até que o número de pacientes do mês fosse totalizado. 


\subsection{PROCEDIMENTO PARA A COLETA DE DADOS}

A coleta dos dados foi realizada de forma retrospectiva nos prontuários clínicos e contábeis dos pacientes da amostra selecionada, entre os meses de julho e setembro de 2011 pela própria pesquisadora, no SAME do Hospital.

No prontuário clínico, foram levantadas, por meio da anotação de enfermagem, as atividades realizadas, conforme a prescrição de enfermagem e a prescrição médica.

Os procedimentos realizados pela equipe de enfermagem, mediante prescrição médica (como passagem de sondas, realização de eletrocardiograma) também foram considerados como atividades da enfermagem.

As atividades de enfermagem de rotina como massagem de conforto, mudança de decúbito, higiene oral, higiene íntima, verificação de peso, banho no leito, também foram quantificadas para posterior análise.

As anotações de enfermagem foram lidas para verificar se os procedimentos prescritos e checados tanto na prescrição médica como na prescrição de enfermagem foram efetivamente realizados, pois 0 pagamento, pelo convênio, só ocorre se houver o devido registro da atividade executada.

O prontuário contábil do paciente, emitido via sistema informatizado, contém a guia de autorização de internação da operadora do plano de assistência à saúde $e$ as guias de autorizações referentes aos procedimentos, exames, materiais de alto custo. O prontuário contábil não é armazenado com o prontuário clínico, mas pode ser consultado, por meio do sistema informatizado, de qualquer computador, mediante a senha de acesso. Os prontuários contábeis da amostra selecionada foram acessados em um computador do SAME e armazenados e gravados em formato de arquivo, em pen drive, para consulta posterior. 
Para a coleta dos dados, foram elaborados dois instrumentos (APÊNDICES A e B), confeccionados em planilha eletrônica do Excel.

Por meio de consulta ao prontuário clínico do paciente, foram coletados dados referentes à prescrição de enfermagem e a prescrição médica.

Para a coleta dos dados referente à prescrição de enfermagem, foi elaborado um instrumento (APÊNDICE A), contendo as seguintes informações:

1. Nome do paciente;

2. Sexo;

3. Idade;

4. Diagnóstico médico da internação;

5. Operadora de plano de assistência à saúde;

6. Número do atendimento do paciente: o número de atendimento foi colocado para arquivo da pesquisadora, para possível resgate do prontuário, se necessário;

7. Data de internação hospitalar, data de internação na UTI, data da alta da UTI e data da alta hospitalar: estes dados foram utilizados, posteriormente, para cálculo do tempo médio de internação na UTI.

8. Procedimento/atividade de enfermagem presente na prescrição de enfermagem: por meio de leitura do prontuário clínico, foram levantadas todas as atividades de enfermagem realizadas, separadas por tipo de atividade executada e o número total de vezes em que a atividade foi realizada durante a internação na UTI;

9. Quantidade e descrição do material utilizado: por meio de leitura do prontuário clínico, foi verificada a descrição do tipo de material utilizado nas atividades de enfermagem e a respectiva quantidade de material usado na assistência. 
Para a coleta de dados referentes aos procedimentos de enfermagem realizados mediante prescrição médica, foi utilizada também uma planilha eletrônica confeccionada em Excel, (APÊNDICE B), com os seguintes dados:

1. Procedimento/atividade de enfermagem presente na prescrição médica: por meio de leitura do prontuário clínico, foram levantadas todas as atividades de enfermagem realizadas, mediante a prescrição médica, separadas por tipo de atividade executada e o número total de vezes em que a mesma foi realizada durante a internação na UTI.

2. Quantidade de material utilizado: é a soma dos materiais utilizados nas atividades de enfermagem.

3. Quantidade de procedimentos: foi colocada a soma total que cada atividade foi executada.

Posteriormente, foi realizada consulta aos prontuários contábeis dos pacientes selecionados para obtenção das seguintes informações, presentes na planilha (APÊNDICES A e B):

1. Valor do material: foram levantados os valores unitários, em Reais $(R \$)$, dos materiais utilizados nas atividades de enfermagem;

2. Valor total dos materiais: é o valor total dos materiais utilizados nas atividades de enfermagem, obtido com base na multiplicação do valor unitário pela quantidade de material consumido, expresso em Reais ( $R \$)$;

3. Valor do procedimento: é o preço, expresso em Reais $(R \$)$, referente ao pagamento de taxas pelos procedimentos; corresponde ao pagamento pela mão de obra utilizada na realização das atividades; e

4. Valor total do procedimento: obtido com base na multiplicação do valor unitário de cada taxa referente a um procedimento pela quantidade de vezes que esse procedimento foi executado, expresso em Reais $(R \$)$. 


\subsection{PROCEDIMENTOS PARA ANÁLISE E TRATAMENTO DOS DADOS}

As variáveis do estudo foram submetidas à análise descritiva, com apresentação das distribuições, frequências, medidas descritivas, médias e desvio padrão.

Um banco de dados foi criado usando uma planilha eletrônica de Excel para registro, tratamento e apresentação dos dados quantitativos.

A triangulação dos dados foi realizada e consiste nas informações obtidas por mais de uma fonte, corroborando o mesmo fato ou fenômeno. A triangulação dos dados do estudo de caso possibilita que os achados ou conclusões da pesquisa sejam mais convincentes e acurados, já que estão apoiados em diversas fontes de informação. ${ }^{30}$

Ao realizar a triangulação dos dados, os problemas de "validade do constructo" são também abordados, já que as múltiplas fontes de informação utilizadas fornecem várias avaliações sobre o mesmo fenômeno. ${ }^{30}$

Os dados da pesquisa foram apresentados na forma de tabelas e figuras.

\subsection{ASPECTOS ÉTICOS DA PESQUISA}

O estudo foi submetido e aprovado pelo Comitê de Ética em Pesquisa do próprio Hospital em que foi realizada a pesquisa, sob o número de Protocolo 071/11, em 13 de junho de 2011 (ANEXO A). 


\section{APRESENTAÇÃO E DISCUSSÃO DOS RESULTADOS}

De acordo com os objetivos propostos, a apresentação e discussão dos resultados deste estudo estão organizadas em quatro etapas.

Na primeira, está a caracterização da amostra do estudo.

$\mathrm{Na}$ segunda, são apresentados os dados referentes aos procedimentos de enfermagem que são realizados na UTI Cardiológica e o montante financeiro gerado pelas atividades de enfermagem, que são pagas pelas operadoras de planos de assistência à saúde ao hospital.

$\mathrm{Na}$ terceira, apresenta-se a percentagem de faturamento gerado pela enfermagem em relação ao faturamento da UTI.

$\mathrm{Na}$ quarta, estão os dados referentes às ações de enfermagem que são realizadas, mas não recebem pagamento, com a respectiva projeção de estimativa de perda média pelo não pagamento das atividades de enfermagem. Está demonstrada ainda a projeção do faturamento gerado pela enfermagem para os meses estudados e a extrapolação dos dados para um ano.

Para as variáveis qualitativas do estudo (distribuição da amostra conforme gênero, número de pacientes internados/mês, distribuição dos pacientes conforme hipótese diagnóstica à admissão, distribuição das operadoras de planos de assistência à saúde), as estatísticas apresentadas foram as frequências absolutas (n) e as relativas (\%).

Para as variáveis quantitativas (idade, tempo médio de internação na UTI Cardiológica, tempo médio de internação hospitalar, faturamento médio gerado com base na prescrição de enfermagem e prescrição médica, percentual médio gerado apoiado na prescrição de enfermagem e prescrição médica, faturamento médio gerado baseado nas taxas de enfermagem e de materiais utilizados), foram usadas como medidas-resumo a média, a mediana e o desvio-padrão, mínimo e máximo para apontar a variabilidade. 


\subsection{CARACTERIZAÇÃO DA AMOSTRA DO ESTUDO}

A amostra calculada para um período de 3 meses foi de 168 pacientes, considerando um nível de confiança de $95 \%$ e podendo haver um erro amostral de $5 \%$.

Tabela 1 - Demonstrativo sobre o total de pacientes internados na UTI Cardiológica nos meses entre janeiro e março de 2011 - São Paulo, 2011

\begin{tabular}{ccc}
\hline Mês & $\mathbf{n}$ & $\%$ \\
\hline Janeiro & 107 & 33,5 \\
Fevereiro & 102 & 32,0 \\
Março & 110 & 34,5 \\
Total & 319 & 100 \\
\hline
\end{tabular}

Os dados da Tabela 1 demonstram o número total de pacientes internados na UTI Cardiológica nos meses do estudo; os dados evidenciam que, embora o mês de janeiro seja de férias, não houve variação significativa do número de internações, assim como ocorreu com o estudo conduzido por Zunta (2006). ${ }^{11}$

Tabela 2 - Distribuição dos pacientes estudados, nos meses entre janeiro e março de 2011 - São Paulo, 2011

\begin{tabular}{lcc}
\hline Mês & $\mathbf{n}$ & $\%$ \\
\hline Janeiro & 63 & 37,5 \\
Fevereiro & 53 & 31,5 \\
Março & 52 & 31,0 \\
Total & 168 & 100,0 \\
\hline
\end{tabular}

Os dados da Tabela 2 demonstram o número de pacientes que fizeram parte da amostra, nos meses estudados. Houve um maior número 
de pacientes no mês de janeiro de 2011 em razão da maior disponibilidade dos prontuários clínicos e contábeis para coleta dos dados. Os prontuários que foram selecionados no primeiro sorteio e não puderam ser disponibilizados estavam em uso na Auditoria do hospital, em processo de fechamento dos prontuários contábeis e/ou negociação com as operadoras de planos de assistência à saúde.

Tabela 3 - Distribuição dos pacientes conforme gênero, nos meses entre janeiro e março de 2011 - São Paulo, 2011

\begin{tabular}{lcc}
\hline Gênero & $\mathbf{n}$ & $\%$ \\
\hline Masculino & 88 & 52,4 \\
Feminino & 80 & 47,6 \\
Total & 168 & 100 \\
\hline
\end{tabular}

Os dados da Tabela 3 mostram uma diferença estatística muito pequena entre a população feminina e a masculina do estudo. No trabalho de Zunta (2006) ${ }^{11}$ também não foi houve diferença percentual em relação à variável gênero (50,3\% população feminina e $49,7 \%$, masculina). Estudos recentes têm evidenciado que, com o aumento da expectativa de vida da população em geral, a incidência de doenças cardiovasculares nas mulheres também tem aumentado, tornando-se a principal causa de morbidade e mortalidade entre as mulheres maiores de 50 anos de vários países, como EUA e Brasil. ${ }^{35}$ 
Tabela 4 - Demonstrativo da idade média dos pacientes do estudo, o tempo médio de internação na UTI Cardiológica e o tempo médio de internação hospitalar, nos meses entre janeiro e março de 2011 - São Paulo, 2011

\begin{tabular}{lcccccc}
\hline & $\mathbf{n}$ & Média & Mediana & Desvio-padrão & Mínimo & Máximo \\
\hline Idade & 168 & 63,8 & 68 & 16,2 & 21 & 91 \\
Tempo de internação em UTI (dias) & 168 & 4,5 & 3 & 6,0 & 0 & 47 \\
Tempo de internação (dias) & 168 & 10,2 & 7 & 11,7 & 1 & 78 \\
\hline
\end{tabular}

Os dados da Tabela 4 mostram que a idade média dos pacientes foi 63,8 anos, com um tempo médio de internação na UTI Cardiológica de 4,5 dias e um tempo médio de internação hospitalar de 10,2 dias. No trabalho que Zunta (2006) ${ }^{11}$ desenvolveu, $43,4 \%$ da população estudada estavam na faixa etária entre os 60 e 80 anos.

O aumento da expectativa de vida da população traz impacto direto na maior procura pelos serviços de saúde, aumentando assim os gastos com a saúde. A expectativa de vida do brasileiro passará de 72 anos em 2004 para 81 anos em 2050, graças aos avanços da medicina e da melhoria das condições de vida de um modo geral. De acordo com dados do IBGE, em 2050, a idade mediana da população será de 40 anos, e os grupos de zero a 14 anos e maiores de 65 anos terão, ambos, 18\% da população brasileira. Em 2000, 30\% da população eram compostas pelo grupo de zero a 14 anos, e o grupo de maiores de 65 anos representava apenas $5 \%$ da população. $O$ envelhecimento populacional preocupa as operadoras de saúde, pois estas terão uma grande quantidade de clientes idosos e as operadoras não sabem se conseguirão oferecer todos os serviços contratados. $^{36}$ 
Tabela 5 - Demonstrativo sobre a classificação dos diagnósticos médicos de internação dos pacientes do estudo, nos meses entre janeiro e março de 2011 - São Paulo, 2011

\begin{tabular}{lcc}
\hline Diagnóstico & $\mathbf{n}$ & $\%$ \\
\hline Clínico & 103 & 61,3 \\
Cirúrgico & 65 & 38,7 \\
Total & 168 & 100 \\
\hline
\end{tabular}

Os dados da Tabela 5 demonstram que, entre os meses estudados (janeiro e março de 2011), houve predominância dos pacientes com diagnóstico médico clínico em relação ao cirúrgico, embora a UTI do estudo receba pacientes cirúrgicos provenientes, tanto do setor de Hemodinâmica como do Centro Cirúrgico.

Analisando a planilha de ocupação da UTI Cardiológica entre os meses de janeiro e junho de 2011, observamos que este perfil se mantém nos meses citados, com a predominância de pacientes com diagnóstico médico clínico.

Os dados da Tabela 5 diferem dos resultados de Zunta (2006) ${ }^{11}$, que evidenciaram uma predominância de pacientes com diagnóstico de pósoperatório, representando $38,4 \%$ dos pacientes estudados. 
Tabela 6 - Distribuição das hipóteses diagnósticas de internação na UTI Cardiológica entre os pacientes estudados, nos meses entre janeiro e março de 2011 - São Paulo, 2011

\begin{tabular}{|c|c|c|}
\hline HIPÓTESE DIAGNÓSTICA À ADMISSÃO NA UTI & $\mathbf{n}$ & $\%$ \\
\hline Abdome agudo & 1 & 0,6 \\
\hline Aneurisma cerebral & 1 & 0,6 \\
\hline Aneurisma de aorta & 1 & 0,6 \\
\hline Angioplastia de aorta infrarrenal & 5 & 3,0 \\
\hline Angioplastia com stent & 6 & 3,5 \\
\hline Angioplastia de membro inferior & 1 & 0,6 \\
\hline Artrodese de coluna lombar & 1 & 0,6 \\
\hline Artroplastia total de joelho & 3 & 1,8 \\
\hline Artroplastia total de quadril & 1 & 0,6 \\
\hline AVC isquêmico & 1 & 0,6 \\
\hline AVC isquêmico cerebelar & 1 & 0,6 \\
\hline Broncopneumonia & 2 & 1,2 \\
\hline Choque elétrico nas mãos & 1 & 0,6 \\
\hline Choque séptico & 4 & 2,4 \\
\hline Cirurgia de retirada de tumor cerebral & 1 & 0,6 \\
\hline Cirurgia de troca de válvula & 4 & 2,4 \\
\hline Colecistectomia & "'t"' & 2,4 \\
\hline Correção cirúrgica de aneurisma de aorta & 5 & 3,0 \\
\hline Correção cirúrgica de comunicação interatrial & 1 & 0,6 \\
\hline Correção cirúrgica de fratura de tornozelo esquerdo & 1 & 0,6 \\
\hline Correção cirúrgica de hematoma extradural & 1 & 0,6 \\
\hline Correção de artrite séptica de joelho & 1 & 0,6 \\
\hline Correção de estenose de carótida interna & 1 & 0,6 \\
\hline Correção de fratura de falange esquerda & 1 & 0,6 \\
\hline Crise convulsiva & 1 & 0,6 \\
\hline Descompressão e artrodese de coluna cervical & 1 & 0,6 \\
\hline Dheg & 2 & 1,2 \\
\hline Dissecção de aorta & 1 & 0,6 \\
\hline
\end{tabular}




\begin{tabular}{|c|c|c|}
\hline HIPÓTESE DIAGNÓSTICA Ȧ ADMISSÃO NA UTI & $\mathbf{n}$ & $\%$ \\
\hline Dor torácica & 2 & 1,2 \\
\hline Dpoc exacerbado & 1 & 0,6 \\
\hline Encefalopatia hepática & 1 & 0,6 \\
\hline Epilepsia sintomática & 1 & 0,6 \\
\hline Fibrilação atrial & 5 & 3 \\
\hline Flutter atrial & 1 & 0,6 \\
\hline Gastroenterocolite aguda & 1 & 0,6 \\
\hline Hematoma extradural" & 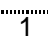 & " 0,6 \\
\hline Hem orragia a/e & 1 & " 0,6 \\
\hline Hemorragia digestiva alta & 2 & 1,2 \\
\hline Hem orragia digestiva baixa & 1 & 0,6 \\
\hline ICC descompensada & 6 & 3,6 \\
\hline Implante de DVP & 2 & 1,2 \\
\hline Implante de ressincronizador & 1 & 0,6 \\
\hline Insuficiência cardíaca por cor anêmico & 1 & 0,6 \\
\hline Insuficiência hepática & 1 & 0,6 \\
\hline Insuficiência renal aguda & 1 & 0,6 \\
\hline Insuficiência respiratória aguda & 15 & 8,9 \\
\hline Intoxicação exógena por cumarínicos & 1 & 0,6 \\
\hline Labirintite & 1 & 0,6 \\
\hline Laparotomia exploradora & 3 & 1,8 \\
\hline Lipotimia & 1 & 0,6 \\
\hline Lobectomia superior & 1 & 0,6 \\
\hline Ooforectomia bilateral & 1 & 0,6 \\
\hline Parto cesárea por pré-eclâmpsia & 1 & 0,6 \\
\hline Parto cesárea por trabalho de parto prematuro & 1 & 0,6 \\
\hline Pericardite & 1 & 0,6 \\
\hline Pleuroscopia com pleurodese & 1 & 0,6 \\
\hline Rebaixamento do nível de consciência & 3 & 1,8 \\
\hline Ressecção de craniofaringeoma & 1 & 0,6 \\
\hline Ressecção de feocromocitoma & 1 & 0,6 \\
\hline
\end{tabular}


CONCLUSĀO

\begin{tabular}{|c|c|c|}
\hline HIPÓTESE DIAGNÓSTICA Ȧ ADMISSÃO NA UTI & $\mathbf{n}$ & $\%$ \\
\hline Retirada de mama & 1 & 0,6 \\
\hline Revascularização do miocárdio & 7 & 4,1 \\
\hline Rtu de próstata & 1 & 0,6 \\
\hline Sepse & 2 & 1,2 \\
\hline Síncope & 5 & 3 \\
\hline Síndrome coronariana aguda & 26 & 15,6 \\
\hline Suboclusão intestinal por fecaloma & 1 & 0,6 \\
\hline Toracostomia exploradora & 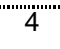 & "'2,4" \\
\hline Tromboembolismo pulmonar & 5 & 3 \\
\hline Urgência dialítica & 1 & 0,6 \\
\hline Total & 168 & 100 \\
\hline
\end{tabular}

Os dados da Tabela 6 mostram que os dois diagnósticos médicos à admissão mais frequentes eram de ordem clínica; o diagnóstico de síndrome coronariana aguda foi evidenciado em 26 dos pacientes estudados (15,6\% da amostra), ratificando a identificação do diagnóstico médico com a UTI Cardiológica. O segundo diagnóstico médico à admissão mais frequente é o de insuficiência respiratória aguda em 15 pacientes do estudo (8,9\% da amostra).

Estes dados assemelham-se aos achados de Zunta (2006) ${ }^{11}$, que demonstrou que os diagnósticos de síndrome coronariana aguda e insuficiência respiratória aguda também foram os mais incidentes dentre os diagnósticos médicos de ordem clínica, com $13,8 \%$ de frequência relativa cada um deles no estudo.

Entre os diagnósticos médico-cirúrgicos, os dados demonstram que os procedimentos de revascularização do miocárdio e angioplastia coronariana com implantação de stent foram os mais frequentes, com $4,1 \%$ e 3,5\% dos casos, respectivamente, evidenciando a identificação da UTI do estudo com os procedimentos invasivos citados, já que ambos referem-se a tratamento de doença coronariana. 
Tabela 7 - Distribuição das operadoras de saúde entre os pacientes do estudo, nos meses entre janeiro e março de 2011 - São Paulo, 2011

\begin{tabular}{|c|c|c|}
\hline OPERADORA & $\mathrm{n}$ & $\%$ \\
\hline A & 43 & 25,6 \\
\hline B & 30 & 17,8 \\
\hline C & 14 & 8,3 \\
\hline D" & 9 & 5,3 \\
\hline E & 8 & 4,7 \\
\hline$F$ & 6 & 3,6 \\
\hline G & 6 & 3,6 \\
\hline H' & 5 & 3 \\
\hline '" & 5 & 3 \\
\hline J' & 5 & 3 \\
\hline '"' & 4 & 2,4 \\
\hline M & 4 & 2,4 \\
\hline N & 4 & 2,4 \\
\hline O & 3 & 1,8 \\
\hline$P$ & 3 & 1,8 \\
\hline Q & 3 & 1,8 \\
\hline $\mathrm{R}$ & 2 & 1,2 \\
\hline S & 2 & 1,2 \\
\hline T' & 2 & 1,2 \\
\hline U' & 2 & 1,2 \\
\hline "v"' & "'?"' & 0,6 \\
\hline "' & 1 & 0,6 \\
\hline "'z'" & 1 & 0,6 \\
\hline$A A$ & 1 & 0,6 \\
\hline$A B$ & 1 & 0,6 \\
\hline $\mathrm{AC}$ & 1 & 0,6 \\
\hline$A D$ & 1 & 0,6 \\
\hline AE & 1 & 0,6 \\
\hline Total & 168 & 100 \\
\hline
\end{tabular}


Os dados da Tabela 7 demonstram que as três primeiras operadoras de assistência à saúde (A, B e C) detêm $51,7 \%$ de todos os atendimentos realizados na UTI Cardiológica; somando apenas as operadoras de assistência à saúde $A+B$, temos $43,4 \%$ dos pacientes internados na UTI.

No trabalho de Zunta $(2006)^{11}$, os achados foram semelhantes, pois também três operadoras de saúde respondiam por $50,3 \%$ do faturamento da amostra selecionada.

Atualmente, os hospitais têm tentado "diluir" o faturamento entre as várias operadoras, para que o valor gerado por apenas uma delas não seja o principal responsável pela receita da instituição, e o hospital não se torne dependente financeiramente de um pequeno número de operadoras.

Fazer com que o faturamento do hospital seja dividido entre várias operadoras de planos de assistência à saúde, é a chamada "pulverização" do faturamento; este é um termo utilizado no meio de Faturamento e na área Comercial dos hospitais e representa a forma que as instituições hospitalares utilizam para não se tornarem dependentes de apenas uma ou duas operadoras de saúde.

Um recurso que os hospitais empregam, para que ocorra esta "pulverização" das operadoras de planos de assistência à saúde, é o gerenciamento de leitos; o responsável por este setor tem conhecimento do número de pacientes internados por operadora de saúde diariamente e, seguindo orientações da direção do hospital, consegue limitar a internação de pacientes de determinada operadora de saúde, quando esta apresenta problemas de pagamento.

Outra forma é a limitação do agendamento de procedimentos invasivos, realizados pelos setores de Centro Cirúrgico, Hemodinâmica e Centro de Diagnóstico, para determinada operadora de assistência à saúde que apresente problemas com repasse de pagamento à instituição de saúde.

As maiores operadoras de saúde têm vantagens no fechamento de contratos comerciais com os prestadores de serviço, pois como detêm o 
maior número de associados do mercado de saúde, conseguem "barganhar" os reajustes de preços das tabelas vigentes, colocando os hospitais em uma posição de desvantagem comercial, já que estes precisam sujeitar-se às ofertas das operadoras de saúde.

Por outro lado, quando os hospitais precisam negociar preços e tabelas com as operadoras com menor participação no mercado de saúde, os primeiros obtêm melhores formas de remuneração, já que essas operadoras contam com pequena rede referenciada para seus clientes e, por isso, precisam acatar as solicitações de reajustes dos prestadores de serviço. Assim, pode-se notar que, embora algumas operadoras tenham um baixo número de atendimentos em determinado prestador de serviço, elas são responsáveis por gerarem um faturamento expressivo ao hospital, em razão de melhores remunerações das tabelas acordadas.

$\mathrm{Na}$ realização deste estudo, a pesquisadora não teve acesso às tabelas e contratos acordados entre o hospital e as operadoras de saúde; assim, não foi possível apontar qual o tipo de diária (compacta/global) que cada operadora paga ao hospital. 


\subsection{FATURAMENTO GERADO PELOS PROCEDIMENTOS DE ENFERMAGEM}

Nesta etapa, estão demonstrados os dados referentes aos procedimentos realizados pela enfermagem na UTI Cardiológica nos pacientes do estudo, e o valor financeiro decorrente desses procedimentos, com a descrição da quantidade de vezes em que as atividades foram executadas, o número de pacientes que recebeu cada atividade, o valor pago por atividade e o valor médio de cada atividade.

Tabela 8 - Demonstrativo das atividades de enfermagem realizadas nos meses entre janeiro e março de 2011 - São Paulo, 2011

\begin{tabular}{|c|c|c|c|c|c|c|c|c|c|}
\hline Atividades & $\begin{array}{l}\text { Qtde. } \\
\text { de } \\
\text { vezes } \\
\text { que } \\
\text { este } \\
\text { item foi } \\
\text { pago }\end{array}$ & $\begin{array}{c}\text { Qtde. de } \\
\text { pacientes } \\
\text { que este } \\
\text { item foi } \\
\text { pago }\end{array}$ & $\begin{array}{l}\text { Qtde. de } \\
\text { vezes que } \\
\text { esta } \\
\text { atividade } \\
\text { foi } \\
\text { executada }\end{array}$ & $\begin{array}{l}\text { Qtde. de } \\
\text { pacientes } \\
\text { que } \\
\text { recebeu } \\
\text { esta } \\
\text { atividade }\end{array}$ & $\begin{array}{c}\% \text { de } \\
\text { pacientes } \\
\text { que } \\
\text { utilizou o } \\
\text { item }\end{array}$ & $\begin{array}{c}\% \text { de } \\
\text { pacientes } \\
\text { que } \\
\text { utilizou o } \\
\text { item e foi } \\
\text { pago }\end{array}$ & $\begin{array}{l}\text { Média de } \\
\text { vezes } \\
\text { utilizada } \\
\text { por } \\
\text { paciente }\end{array}$ & $\begin{array}{l}\text { Total } \\
\text { pago } \\
\text { por } \\
\text { este } \\
\text { item } \\
\\
(\mathrm{R} \$)\end{array}$ & $\begin{array}{l}\text { Preço } \\
\text { médio } \\
\text { por item } \\
(R \$)\end{array}$ \\
\hline Alimentação enteral & 0 & 0 & 12 & 12 & $7,1 \%$ & $0,0 \%$ & 1 & 0 & 0 \\
\hline Aplicação de pomadas & 274 & 66 & 275 & 68 & $40,2 \%$ & $97,1 \%$ & 4,1 & $\begin{array}{c}6.043 \\
44\end{array}$ & 22,07 \\
\hline $\begin{array}{c}\text { Aspiração } \\
\text { traqueostomia/cânula } \\
\text { orotraqueal/vias } \\
\text { aéreas superiores }\end{array}$ & 14 & 1 & 14 & 1 & $0,6 \%$ & $100,0 \%$ & 14 & 40,56 & 3,00 \\
\hline Banho de aspersão & 0 & 0 & 328 & 118 & $69,8 \%$ & $0,0 \%$ & 2,8 & 0 & 0 \\
\hline Banho no leito & 10 & 5 & 329 & 101 & $59,8 \%$ & $5,0 \%$ & 3,25 & 42,76 & 4,28 \\
\hline Capnografia & 93 & 12 & 93 & 12 & $7,1 \%$ & $100,0 \%$ & 7,7 & $\begin{array}{c}4.277 \\
39\end{array}$ & 46,02 \\
\hline $\begin{array}{l}\text { Curativo cateter } \\
\text { venoso central }\end{array}$ & 91 & 34 & 114 & 45 & $26,6 \%$ & $75,6 \%$ & 2,5 & $\begin{array}{c}1.846 \\
66\end{array}$ & 20,24 \\
\hline Curativo de dreno & 7 & 3 & 62 & 24 & $14,2 \%$ & $12,5 \%$ & 2,6 & 183,12 & 27,09 \\
\hline $\begin{array}{c}\text { Curativo ferida } \\
\text { operatória }\end{array}$ & 152 & 42 & 230 & 77 & $45,6 \%$ & $54,5 \%$ & 3,0 & $\begin{array}{c}5.315 \\
26\end{array}$ & 34,95 \\
\hline $\begin{array}{c}\text { Curativo } \\
\text { traqueostomia }\end{array}$ & 23 & 1 & 23 & 1 & $0,6 \%$ & $100,0 \%$ & 23,0 & $\begin{array}{c}4.762 \\
42\end{array}$ & 201,29 \\
\hline Curativo úlcera pressão & 24 & 8 & 24 & 8 & $4,7 \%$ & $100,0 \%$ & 3,0 & 994,29 & 42,02 \\
\hline Glicemia capilar & 2761 & 163 & 2794 & 168 & $100 \%$ & $97,0 \%$ & 16,6 & $\begin{array}{c}21.602 \\
06\end{array}$ & 7,82 \\
\hline
\end{tabular}




\begin{tabular}{|c|c|c|c|c|c|c|c|c|c|}
\hline Atividades & $\begin{array}{l}\text { Qtde. } \\
\text { de } \\
\text { vezes } \\
\text { que } \\
\text { este } \\
\text { item foi } \\
\text { pago }\end{array}$ & $\begin{array}{c}\text { Qtde. de } \\
\text { pacientes } \\
\text { que este } \\
\text { item foi } \\
\text { pago }\end{array}$ & $\begin{array}{l}\text { Qtde. de } \\
\text { vezes que } \\
\text { esta } \\
\text { atividade } \\
\text { foi } \\
\text { executada }\end{array}$ & $\begin{array}{l}\text { Qtde. de } \\
\text { pacientes } \\
\text { que } \\
\text { recebeu } \\
\text { esta } \\
\text { atividade }\end{array}$ & $\begin{array}{l}\% \text { de } \\
\text { pacientes } \\
\text { que } \\
\text { utilizou o } \\
\text { item }\end{array}$ & $\begin{array}{c}\% \text { de } \\
\text { pacientes } \\
\text { que } \\
\text { utilizou o } \\
\text { item e foi } \\
\text { pago }\end{array}$ & $\begin{array}{l}\text { Média de } \\
\text { vezes } \\
\text { utilizada } \\
\text { por } \\
\text { paciente }\end{array}$ & $\begin{array}{l}\text { Total } \\
\text { pago } \\
\text { por } \\
\text { este } \\
\text { item } \\
\text { (R\$) }\end{array}$ & $\begin{array}{l}\begin{array}{l}\text { Preço } \\
\text { médio }\end{array} \\
\text { por item } \\
\text { (R\$) }\end{array}$ \\
\hline $\begin{array}{l}\text { Diálise peritoneal } \\
\text { intermitente }\end{array}$ & 2 & 2 & 2 & 2 & $1,2 \%$ & $100,0 \%$ & 1,0 & $\begin{array}{c}4.610 \\
80\end{array}$ & $\begin{array}{c}2.728,2 \\
8\end{array}$ \\
\hline Enteroclisma & 44 & 26 & 44 & 26 & $15,4 \%$ & $100,0 \%$ & 1,7 & 584,72 & 13,31 \\
\hline Higiene couro cabeludo & 0 & 0 & 96 & 38 & $22,5 \%$ & $0,0 \%$ & 2,5 & 0 & 0 \\
\hline Higiene íntima & 0 & 0 & 1502 & 157 & $93,4 \%$ & $0,0 \%$ & 9,6 & 0 & 0 \\
\hline Higiene ocular & 19 & 1 & 204 & 72 & $42,8 \%$ & $1,4 \%$ & 2,8 & 10,14 & 0,55 \\
\hline Higiene oral & 286 & 23 & 1545 & 164 & $97,6 \%$ & $14,0 \%$ & 9,42 & 512,07 & 1,79 \\
\hline Inalação & 259 & 19 & 259 & 19 & $11,3 \%$ & $100,0 \%$ & 13,6 & $\begin{array}{l}4.906 \\
07\end{array}$ & 18,97 \\
\hline $\begin{array}{l}\text { Instalação de placa } \\
\text { hidrocoloide }\end{array}$ & 8 & 7 & 8 & 7 & $4,2 \%$ & $100,0 \%$ & 1,1 & 316,03 & 37,40 \\
\hline $\begin{array}{l}\text { Instalação de protetor } \\
\text { de calcâneos }\end{array}$ & 14 & 7 & 14 & 7 & $4,2 \%$ & $100,0 \%$ & 2,0 & 273,78 & 20,25 \\
\hline Instalar uripen & 28 & 9 & 28 & 9 & $5,3 \%$ & $100,0 \%$ & 3,1 & 420,81 & 14,65 \\
\hline Irrigação vesical & 1 & 1 & 1 & 1 & $0,6 \%$ & $100,0 \%$ & 1,0 & 5,07 & 3,00 \\
\hline Manta térmica & 1 & 1 & 1 & 1 & $0,6 \%$ & $100,0 \%$ & 1,0 & 231,53 & 137,00 \\
\hline Marca passo & 5 & 1 & 5 & 1 & $0,6 \%$ & $100,0 \%$ & 5,0 & 992,34 & 195,73 \\
\hline Massagem de conforto & 1274 & 124 & 1667 & 162 & $96,4 \%$ & $76,5 \%$ & 10,3 & $\begin{array}{l}1.766 \\
05\end{array}$ & 1,39 \\
\hline Meias antitrombóticas & 3 & 3 & 4 & 4 & $2,4 \%$ & $75,0 \%$ & 1,0 & 400,53 & 118,50 \\
\hline Nutrição parenteral & 0 & 0 & 3 & 1 & $0,0 \%$ & 0 & 0 & 0 & 0 \\
\hline Ordenha de dreno & 0 & 0 & 46 & 17 & $10,1 \%$ & $0,0 \%$ & 2,7 & 0,00 & 0 \\
\hline $\begin{array}{l}\text { Pressão arterial invasiva } \\
\text { (curativo, troca de } \\
\text { transdutor, passagem) }\end{array}$ & 63 & 18 & 67 & 22 & $13,0 \%$ & $81,8 \%$ & 3,0 & $\begin{array}{c}14.220 \\
, 56\end{array}$ & 227,42 \\
\hline Pressão Intra-abdominal & 2 & 2 & 4 & 2 & $1,2 \%$ & $100,0 \%$ & 2,0 & 163,93 & 97,00 \\
\hline $\begin{array}{l}\text { Preparo de corpo pós- } \\
\text { óbito }\end{array}$ & 0 & 0 & 7 & 7 & $4,2 \%$ & $0,0 \%$ & 1 & 0 & 0 \\
\hline $\begin{array}{l}\text { PICC (cateter central de } \\
\text { inserção periférica) }\end{array}$ & 15 & 4 & 15 & 4 & $2,4 \%$ & $100,0 \%$ & 3,8 & $\begin{array}{l}5.383 \\
99\end{array}$ & 353,98 \\
\hline Punção venosa & 250 & 93 & 251 & 94 & $56 \%$ & $98,9 \%$ & 2,7 & $\begin{array}{c}8.062 \\
99\end{array}$ & 32,24 \\
\hline Pressão venosa central & 335 & 11 & 1212 & 40 & $23,8 \%$ & $27,5 \%$ & 30,3 & $\begin{array}{c}2.813 \\
68\end{array}$ & 8,41 \\
\hline
\end{tabular}




\begin{tabular}{|c|c|c|c|c|c|c|c|c|c|}
\hline Atividades & $\begin{array}{l}\text { Qtde. } \\
\text { de } \\
\text { vezes } \\
\text { que } \\
\text { este } \\
\text { item foi } \\
\text { pago }\end{array}$ & $\begin{array}{c}\text { Qtde. de } \\
\text { pacientes } \\
\text { que este } \\
\text { item foi } \\
\text { pago }\end{array}$ & $\begin{array}{l}\text { Qtde. de } \\
\text { vezes que } \\
\text { esta } \\
\text { atividade } \\
\text { foi } \\
\text { executada }\end{array}$ & $\begin{array}{c}\text { Qtde. de } \\
\text { pacientes } \\
\text { que } \\
\text { recebeu } \\
\text { esta } \\
\text { atividade }\end{array}$ & $\begin{array}{c}\% \text { de } \\
\text { pacientes } \\
\text { que } \\
\text { utilizou o } \\
\text { item }\end{array}$ & $\begin{array}{c}\% \text { de } \\
\text { pacientes } \\
\text { que } \\
\text { utilizou o } \\
\text { item e foi } \\
\text { pago }\end{array}$ & $\begin{array}{c}\text { Média de } \\
\text { vezes } \\
\text { utilizada } \\
\text { por } \\
\text { paciente }\end{array}$ & $\begin{array}{l}\text { Total } \\
\text { pago } \\
\text { por } \\
\text { este } \\
\text { item } \\
\\
\text { (R\$) }\end{array}$ & $\begin{array}{l}\begin{array}{l}\text { Preço } \\
\text { médio }\end{array} \\
\text { por item } \\
\text { (R\$) }\end{array}$ \\
\hline $\begin{array}{l}\text { Restrição/ enfaixamento } \\
\text { de membros inferiores }\end{array}$ & 30 & 13 & 174 & 21 & $12,5 \%$ & $61,9 \%$ & 8,3 & 907,53 & 29,83 \\
\hline $\begin{array}{l}\text { Retirada de introdutor } \\
\text { percutâneo }\end{array}$ & 0 & 0 & 2 & 1 & $0,6 \%$ & $0,0 \%$ & 2 & 0 & 0 \\
\hline $\begin{array}{c}\text { Sondagem gástrical } \\
\text { enteral }\end{array}$ & 23 & 16 & 23 & 16 & $9,5 \%$ & $100,0 \%$ & 1,4 & $\begin{array}{l}20.239 \\
, 00\end{array}$ & 855,41 \\
\hline Sondagem vesical & 27 & 22 & 27 & 22 & $13,1 \%$ & $100,0 \%$ & 1,2 & $\begin{array}{c}2.918 \\
13\end{array}$ & 107,92 \\
\hline Sondagem retal & 2 & 1 & 2 & 1 & $0,6 \%$ & $100,0 \%$ & 2,0 & 15,21 & 9,00 \\
\hline Transporte de paciente & 0 & 0 & 72 & 48 & $28,6 \%$ & $0,0 \%$ & 1,5 & 0 & 0 \\
\hline Tricotomia facial & 2 & 1 & 58 & 30 & $17,8 \%$ & $3,3 \%$ & 1,9 & 3,38 & 2,00 \\
\hline $\begin{array}{l}\text { Tricotomia pré- } \\
\text { operatória }\end{array}$ & 7 & 6 & 24 & 22 & $13,1 \%$ & $27,3 \%$ & 1,1 & 310,96 & 46,00 \\
\hline $\begin{array}{l}\text { Troca de bolsa de } \\
\text { colostomia }\end{array}$ & 0 & 0 & 1 & 1 & $0,0 \%$ & 0 & 0 & 0 & 0 \\
\hline $\begin{array}{l}\text { Troca de filtro } \\
\text { bacteriano }\end{array}$ & 112 & 12 & 112 & 12 & $7,1 \%$ & $100,0 \%$ & 9,3 & $\begin{array}{c}10.342 \\
, 80\end{array}$ & 92,73 \\
\hline $\begin{array}{c}\text { Troca de selo d'água de } \\
\text { dreno }\end{array}$ & 49 & 23 & 54 & 26 & $15,5 \%$ & $88,5 \%$ & 2,1 & 880,49 & 17,97 \\
\hline Verificar peso & 0 & 0 & 852 & 168 & $100 \%$ & $0,0 \%$ & 5,1 & 0 & 0 \\
\hline
\end{tabular}

A Tabela 8 é composta pelos seguintes dados:

- $\quad$ Quantidade de vezes que este item foi pago: este resultado mostra a quantidade de vezes que o item foi realizado, independente de ter sido feito mais de uma vez para um mesmo paciente;

- $\quad$ Quantidade de pacientes que este item foi pago: este resultado mostra a quantidade de pacientes que recebeu esta atividade, independente da quantidade de vezes recebida, e este item foi pago de forma discriminada (direta);

- $\quad$ Quantidade de vezes que esta atividade foi executada: é o valor total do número de vezes que cada atividade foi executada; 
- $\quad$ Quantidade de pacientes que recebeu esta atividade: este resultado mostra a quantidade de pacientes que recebeu esta atividade, independente da quantidade de vezes recebida (podendo ser paga direta ou indiretamente);

- $\quad \%$ de pacientes que utilizou o item: considerando o total de 168 pacientes, qual o percentual de pacientes que recebeu aquela atividade, independente de ter sido paga de forma discriminada ou não;

- $\quad \%$ de pacientes que usaram o item e foi pago: considerando o total de pacientes que recebeu esta atividade, qual o percentual de pacientes que recebeu a atividade e gerou pagamento;

- Média de vezes utilizada por paciente: este resultado mostra a quantidade média de vezes que um mesmo paciente recebeu cada atividade;

- $\quad$ Total pago por este item: qual o valor monetário total pago para o item (material ou taxa), considerando todos os pacientes que receberam esta atividade; e

- $\quad$ Preço médio por item: preço unitário (em $\mathrm{R} \$$ ) pago por atividade.

Os dados da Tabela 8 demonstram que, os cuidados com higiene (banho no leito, banho de aspersão, higiene íntima, higiene oral e higiene ocular), estão entre as atividades com maiores frequências; estas constam em prescrição de enfermagem, devendo ser checados pelo técnico de enfermagem e demandam um grande tempo de assistência da enfermagem.

O banho de aspersão foi realizado 328 vezes para 118 pacientes do estudo (70,2\% da amostra). No entanto, não há valor financeiro agregado a esta atividade, para nenhum paciente do estudo.

O banho no leito foi executado 329 vezes para 101 pacientes do estudo $(60,1 \%$ da amostra), com uma média de 3,1 procedimentos para cada paciente; o valor médio de cada banho no leito foi de $R \$ 4,28$ reais e o valor total gerado foi de $\mathrm{R} \$ 42,76$. Em nenhum dos pacientes da amostra, o valor estava relacionado à taxa (mão de obra) do procedimento, mas, sim ao material utilizado (sabonete líquido). Este resultado assemelha-se aos resultados do trabalho de Zunta $(2006)^{11}$, que mostraram que, nos prontuários contábeis analisados no local onde realizou seu estudo, havia a 
cobrança de luvas de banho, com um faturamento médio, por paciente, de $\mathrm{R} \$ 49,09$, mas, não a cobrança de taxas. Isto demonstra a diferença de cobrança entre os hospitais, que pode influenciar no resultado do faturamento das instituições.

Em relação à realização de curativos, nota-se que o curativo de ferida operatória e o de cateter venoso central estão entre os mais frequentes. Ambos os procedimentos são prescritos pelo enfermeiro. $O$ curativo de ferida operatória foi realizado 230 vezes, para 77 pacientes do estudo (45,6\% da amostra), com uma média de 3,6 curativos para cada paciente, a um custo unitário médio de $R \$ 34,95$, o que resultou em uma receita de $R \$$ $5.315,26$. Já o curativo de cateter venoso central, foi realizado 114 vezes, para 45 pacientes, com uma média de 2,5 curativos para cada paciente; o valor médio de cada procedimento foi de $R \$ 20,24$, o que gerou um faturamento total de $\mathrm{R} \$ 1.846,66$. No trabalho de Zunta $(2006)^{11}$, o faturamento médio por paciente, em relação aos curativos, foi de $R \$ 426,05$ e também não há especificação sobre o tipo e local do curativo realizado.

Os dados evidenciam o baixo número de curativos de úlcera por pressão; foram realizados apenas 24 procedimentos para oito pacientes ( $4,7 \%$ da amostra); o valor médio de cada curativo foi de $R \$ 42,02$ e o valor total gerado foi de $R \$ 994,29$. Os curativos de úlcera por pressão são prescritos e realizados pelo enfermeiro. Nos prontuários contábeis analisados, não havia taxa específica referente à realização de curativo de úlcera por pressão; em alguns casos, havia uma taxa referente à realização de curativo, independente do tipo e do local do curativo. No entanto, a realização de curativos de úlcera por pressão demanda, geralmente, maior tempo de trabalho do enfermeiro e maior quantidade de materiais de consumo e a ausência de taxas especificando o tipo e local do curativo realizado impacta na geração de receita à Instituição. Embora o perfil da amostra seja de pacientes idosos, com alto risco para lesões de pele, a incidência de úlcera por pressão na UTI estudada é baixa; conforme o indicador de qualidade estabelecido na Instituição, a porcentagem aceitável de úlcera por pressão é de $1 \%$ dos pacientes internados ao mês. Os 
cuidados de enfermagem como mudança de decúbito a cada 2 horas constam em prescrição de enfermagem e recebem o acompanhamento do grupo de estudos dermatológicos do hospital.

A mensuração da glicemia capilar foi realizada a todos os pacientes do estudo; nota-se um grande número dessa atividade, 2.794 vezes, com uma média de 16,9 mensurações por paciente. Como o perfil da amostra estudada é de uma população idosa, há um aumento de doenças crônicas, como o Diabetes mellitus, o que requer uma monitorização mais frequente da glicemia capilar. Alem disso, é rotina da unidade a realização de glicemia capilar pré-prandial, a todos os pacientes, e esta atividade consta em prescrição médica da UTI Cardiológica. O valor médio da glicemia capilar foi de $R \$ 7,82$, com o valor total de $R \$ 21.602,06$.

A realização de eletrocardiograma ocorreu 197 vezes, para 149 pacientes do estudo $(88,2 \%$ da amostra). Este procedimento tem uma frequência alta porque, por se tratar de UTI Cardiológica, é rotina do serviço a realização de ECG a todos os pacientes que são admitidos na unidade e consta em prescrição médica. A média é de 1,4 procedimentos por paciente, a um valor médio de $R \$ 17,28$ por exame, o que gerou $R \$ 2.979,47$ de receita.

O procedimento de higiene íntima apresentou uma alta frequência, sendo realizada 1.502 vezes, para 157 pacientes do estudo $(93,4 \%$ da amostra) e também não apresentou valor financeiro vinculado em nenhum dos prontuários contábeis analisados. Na UTI Cardiológica estudada, a realização de higiene intima é uma rotina que consta na prescrição de enfermagem a todos os pacientes, a cada 6 horas, o que explica o grande número de vezes que o procedimento foi executado.

O procedimento de higiene oral foi realizado 1.545 vezes, para 164 pacientes (97\% da amostra), com uma média de 9,42 procedimentos por paciente; seu valor médio foi de $R \$ 1,79$, o que gerou $R \$ 512,07$ de receita. Também como ocorreu com o banho de aspersão anteriormente citado, em nenhum dos prontuários contábeis consultados havia pagamento de taxa 
referente à higiene oral e o valor apresentado nos dados da Tabela 9 referese ao pagamento dos materiais usados no procedimento (antisséptico bucal, escova de dentes, creme dental). No trabalho de Zunta (2006) ${ }^{11}$, havia a cobrança, nos prontuários contábeis, de taxa relacionada à higiene oral, o que demonstrou um faturamento médio, por paciente, de $\mathrm{R} \$ 11,06$.

A atividade inalação foi realizada 259 vezes para 19 pacientes $(11,3 \%$ da amostra), com uma média de 13,6 inalações para cada paciente; o valor financeiro médio de cada uma foi de $R \$ 18,97$, e a receita gerada total foi de $\mathrm{R} \$ 4.906,07$. Esta frequência absoluta elevada do procedimento condiz com a alta incidência de diagnóstico médico de admissão de insuficiência respiratória, da amostra estudada. Este item apresentou muita variação de cobrança, entre os prontuários contábeis analisados. Para algumas operadoras, havia a taxa referente a cada inalação realizada, acrescida dos materiais envolvidos no procedimento e o oxigênio necessário à inalação. Para outras, só o pagamento de uma taxa única, que já incluía os materiais e o oxigênio, já que estes não eram cobrados na conta hospitalar. E para outras operadoras, havia a cobrança apenas do inalador, sem o pagamento pelo oxigênio e/ou taxa referente à mão de obra.

A massagem de conforto foi realizada no total de 1.667 vezes, para 162 pacientes do estudo (76,5\% da amostra), com uma média de 10,3 procedimentos para cada paciente. O valor médio pago por esse procedimento foi de $R \$ 1,39$ e o valor total gerado foi de $R \$ 1.766,05$. Nos prontuários contábeis do estudo, não constavam pagamento de taxa referente a esse procedimento; o valor apresentado nos dados da Tabela 8 refere-se à remuneração pelo material utilizado como creme hidratante. A massagem de conforto consta em prescrição de enfermagem, sendo rotina da UTI Cardiológica sua realização a cada 6 horas para todos os pacientes, o que explica uma frequência absoluta alta para uma amostra de pacientes que permaneceu na UTI em média 4,5 dias. No estudo de Zunta (2006) ${ }^{11}$, a massagem de conforto constava como taxa em prontuário contábil, e, portanto, sua realização gerava um pagamento direto, com o faturamento médio de $\mathrm{R} \$ 36,85$ por paciente do estudo. 
Os dados referentes à punção venosa mostram que houve 251 punções venosas em 94 pacientes (56\% da amostra), com uma média de 2,7 punções venosas para cada paciente. Como o tempo de internação da amostra estudada foi de 4,5dias, a média apresentada foi um pouco alta, mas deve-se considerar que a amostra compôs-se de pacientes idosos, com peles friáveis e com maior fragilidade capilar.

Quanto à mensuração da pressão venosa central (PVC), foram realizadas 1.212 mensurações para 40 pacientes estudados $(23,8 \%$ da amostra), com uma média de 30,4 medidas para cada paciente. $O$ valor financeiro médio para cada mensuração foi de $R \$ 8,41$, o que gerou uma receita de $\mathrm{R} \$ 2.813,68$. Este procedimento deve constar em prescrição médica e a mensuração da PVC é realizada por meio de transdutor de pressão acoplado ao monitor multiparâmetros à beira do leito. A maioria dos prontuários contábeis analisados apresentava uma taxa diária sobre o uso desse monitor. Em algumas contas hospitalares, constava apenas o pagamento dos materiais utilizados e, em outras operadoras, havia o pagamento de apenas a taxa referente ao uso do monitor, sem pagamento pelos materiais usados. $O$ preço médio do transdutor de pressão, neste estudo, foi de $\mathrm{R} \$ 106,00$ e o valor da taxa relacionada a esta atividade é inferior ao preço do material utilizado, o que demonstra que é necessária uma revisão, pelo prestador, para uma melhor remuneração para esse procedimento.

A mensuração de peso foi realizada para todos os pacientes da pesquisa (100\% da amostra), no total de 852 vezes. No entanto, pelos dados pode-se notar que não houve valor financeiro vinculado a esse item, pois não houve pagamento por esta atividade, para nenhum dos pacientes da amostra. A atividade é uma rotina da unidade de estudo, sendo realizada diariamente, às $6 \mathrm{~h}$ da manhã, pelo plantão noturno e consta em prescrição de enfermagem. A verificação do peso é feita na própria cama do paciente e anotada na folha diária de controles da UTI. Como se trata de uma UTI Cardiológica, a mensuração do peso é de fundamental importância, pois o perfil da clientela atendida é de pacientes cardiopatas e idosos que têm alto 
risco para retenção de líquidos, o que pode sobrecarregar a função cardíaca já comprometida desses pacientes.

Alguns procedimentos não apresentaram valor financeiro agregado para nenhum paciente que recebeu o procedimento; é o caso dos itens ordenha de dreno, preparo de corpo pós-óbito, retirada de transdutor venoso, transporte de paciente intra-hospitalar e mensuração de peso. A ausência de taxas relacionadas a esses procedimentos revela uma desvalorização da assistência de enfermagem, já que são procedimentos que fazem parte do cuidado, demandam tempo do enfermeiro e não são devidamente remunerados por eles. Geralmente, os itens acima relacionados estão incluídos na diária hospitalar e, portanto, não constam nos contratos comerciais entre prestadores e operadoras de saúde, não gerando receita aos hospitais.

Em pacientes em pós-operatório imediato de cirurgia cardíaca (revascularização do miocárdio ou troca de válvula cardíaca), a ordenha dos drenos (mediastino e/ou pleurais) é realizada de uma em uma hora nas primeiras 12 horas de estada na UTI, demandando tempo da assistência de enfermagem; caso esse procedimento não seja realizado adequadamente, o paciente poderá evoluir com retenção de sangue na cavidade pericárdica e, em casos extremos, evoluir para tamponamento cardíaco, uma complicação grave no pós-operatório.

O transporte intra-hospitalar de pacientes da UTI é um procedimento que exige a presença de um médico, um técnico de enfermagem e um enfermeiro; além disso, é uma situação que requer a atenção da equipe como um todo, em especial em relação à ventilação do paciente (quando este se encontra com entubação orotraqueal), infusão das drogas vasoativas e manuseio dos equipamentos médicos (como bomba de infusão contínua, ventilador mecânico de transporte, monitor multiparâmetros). O transporte intra-hospitalar inicia-se com o preparo do paciente na UTI, quando este é transferido para uma maca de transporte; posteriormente, ocorre a instalação dos equipamentos médicos de transporte e o preparo do prontuário clínico. $\mathrm{O}$ transporte intra-hospitalar só termina quando o 
paciente retorna à UTI, é transferido para a cama e tem todos os seus equipamentos novamente instalados.

Os procedimentos que foram $100 \%$ pagos pelas operadoras são:

- Curativo de traqueostomia;

- Irrigação vesical;

- Instalação de uripen;

- Monitorização de marca-passo temporário;

- Passagem de sonda vesical;

- Mensuração de pressão intra-abdominal;

- Inalação;

- Passagem de sonda gástrica/enteral;

- Troca de filtro bacteriano;

- Mensuração de capnografia;

- Instalação de placa hidrocoloide;

- Instalação de protetor de calcâneos;

- Cateter central de inserção periférica - PICC (passagem e curativos);

- Passagem de sonda retal;

- Aspiração de traqueostomia, cânula orotraqueal e vias aéreas superiores;

- Instalação de manta térmica;

- Realização de diálise peritoneal intermitente; e

- Realização de enteroclisma

Os dados da Tabela 8 evidenciam 48 procedimentos realizados pela enfermagem; destes, 18 procedimentos $(37,5 \%)$ têm $100 \%$ de pagamento pelas operadoras de saúde. No trabalho de Zunta (2006) ${ }^{11}$, foram descritos 22 procedimentos de enfermagem e todos (100\%) geravam receita para a instituição estudada.

Ao analisar os dados da Tabela 8, nota-se que os procedimentos da prescrição de enfermagem que mais contribuíram para o faturamento da amostra selecionada foram a troca de filtro bacteriano ( $R \$ 10.342,80)$, a realização de punção venosa ( $\mathrm{R} \$ 8.062,99)$, o curativo de ferida operatória $(R \$ 5.315,26)$ e o curativo de traqueostomia $(R \$ 4.762,42)$. 
Os procedimentos provenientes da prescrição médica que mais geraram faturamento foram a realização de glicemia capilar ( $R \$ 21.602,06)$, passagem de sonda gástrica/enteral $(R \$ 20.239,00)$ e passagem de pressão arterial invasiva ( $R \$ 14.220,56)$.

Os dados da Tabela 8 evidenciam que os procedimentos de nutrição parenteral e troca de bolsa de colostomia, embora tenham sido descritos nos prontuários clínicos analisados, não geraram pagamento em forma de taxa e/ou dos materiais relacionados à atividade executada, pois não constavam dos prontuários contábeis dos respectivos pacientes. Assim, embora constem na Tabela 8 como tendo sido realizados, não possuem valor financeiro agregado, por não terem gerado receita, o que denota perda de faturamento para o hospital.

Tabela 9 - Faturamento médio gerado, com base na prescrição de enfermagem e prescrição médica por paciente, nos meses entre janeiro e março de 2011- São Paulo, 2011

\begin{tabular}{|c|c|c|c|c|c|}
\hline & Média & Mediana & Desvio-padrao & Minimo & Máximo \\
\hline Total de valores discriminados & 773,98 & 206,64 & $2.185,91$ & 0,00 & $22.395,10$ \\
\hline Prescriça de enrermagem - total & 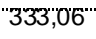 & 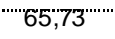 & T.237,75 & 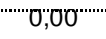 & T4.218,T9 \\
\hline Prescriçao medica - tötal' & 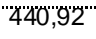 & "1"16,01"' & $1.149,09$ & 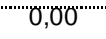 & $8.177,51$ \\
\hline Prescriçao de enfermagem-material & "261,67" & "56",76" & 923,42 & 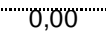 & $9.622,57$ \\
\hline Prescriçao de enfermagem - mäo de obra & 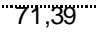 & 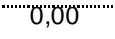 & 378,59 & 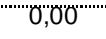 & $4.595,62$ \\
\hline Prescriçao medica-materiäl & "322, & 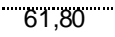 & 961,71 & 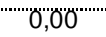 & $6.873,35$ \\
\hline
\end{tabular}

Os dados da Tabela 9 evidenciam que, em média, a prescrição de enfermagem e a prescrição médica geraram juntas $R \$ 773,98$ por paciente do estudo; deste valor, $R \$ 333,06$ advêm da prescrição de enfermagem e $R \$$ 440,92 da prescrição médica. Em relação ao valor gerado pela prescrição de 
enfermagem, $R \$ 261,67$ correspondem aos materiais de consumo utilizados pela enfermagem na prestação da assistência e $R \$ 71,39$, ao pagamento de taxas (mão de obra). Já em relação à prescrição médica, do total de $R$ \$ $440,92, R \$ 322,51$ correspondem aos materiais de consumo utilizados pela enfermagem e $R \$ 118,41$, ao pagamento de taxas discriminadas nas contas hospitalares. Isto demonstra que, o faturamento gerado pelas atividades de enfermagem, tanto com base na prescrição médica como na prescrição de enfermagem, é, em sua maior parte, em razão do pagamento dos materiais de consumo utilizados na prestação dos cuidados de enfermagem, o que denota um subpagamento do tempo despendido pelo pessoal da enfermagem.

O atual aumento dos custos em saúde é, em grande parte, devido a incorporação de novas tecnologias na prática assistencial, o que demanda um grande investimento por parte dos hospitais; por outro lado, a aquisição de novos equipamentos requer mão de obra especializada e, portanto, mais dispendiosa; além disso, diferentemente do que ocorre na área industrial, no setor saúde, as novas tecnologias não substituem as já existentes, mas somam-se a elas e os prestadores de serviço, para que possam continuar competindo no mercado, agregam novos aparelhos, sem que possam repassar estes custos às operadoras de saúde, arcando com o investimento aplicado nessas aquisições.

Os dados da Tabela 9 demonstram que as atividades de enfermagem geradas pela prescrição médica produziram uma receita maior que as atividades geradas pela prescrição de enfermagem. Estes dados contrapõem-se ao achado do estudo de Zunta (2006) ${ }^{11}$, que demonstrou que o faturamento gerado pela prescrição de enfermagem era de $R \$ 1.230,33$ e o faturamento gerado pela prescrição médica, de $R \$ 508,57$.

Uma diferença importante entre este estudo e o de Zunta (2006) ${ }^{11}$ é que este último foi realizado em uma instituição hospitalar privada com regras comerciais muito bem definidas em relação às operadoras de planos de assistência à saúde, com taxas de enfermagem já acordadas em contrato. Já na pesquisa realizada na UTI Cardiológica, o hospital não 
possuía uma uniformidade de cobrança em relação às taxas referentes aos procedimentos de enfermagem.

Ao analisar as contas hospitalares estudadas, percebeu-se uma incoerência entre os procedimentos descritos pela enfermagem e os materiais que eram cobrados nos prontuários contábeis, causando perda de faturamento para o hospital.

Os prontuários contábeis estudados possuíam uma discrepância muito grande de cobrança em relação aos procedimentos de enfermagem; por exemplo, para a cobrança de glicemia capilar; para algumas operadoras de plano de assistência à saúde, havia a cobrança dos materiais envolvidos no procedimento (fita reagente, lanceta), a cobrança de uma taxa referente ao uso do glicosímetro e uma taxa referente à mão de obra, paga para cada glicemia capilar realizada e anotada em prontuário clínico. Para outras operadoras de plano de assistência à saúde, havia a cobrança apenas da taxa referente ao uso do glicosímetro; e para outras operadoras de plano de assistência à saúde, havia a cobrança apenas dos materiais envolvidos no procedimento. Isto demonstra, mais uma vez, a importância do enfermeiro na elaboração de contratos e tabelas entre as operadoras de saúde e o hospital, pois é o profissional que conhece todas as atividades envolvidas no cuidado ao paciente $\mathrm{e}$, portanto, pode assegurar que os materiais consumidos em um procedimento, bem como as taxas pertinentes a ele, estejam descritos nos acordos comerciais.

É imprescindível a presença do enfermeiro na análise das contas hospitalares, para que todas as taxas acordadas entre a operadora e o hospital possam ser devidamente cobradas e para que todos os materiais consumidos na prestação do cuidado constem no prontuário contábil, garantindo que não ocorra perda monetária para o hospital. 
Tabela 10 - Percentual médio do faturamento gerado com base na prescrição de enfermagem e prescrição médica, nos meses entre janeiro e março de 2011 - São Paulo, 2011

\begin{tabular}{lccccc}
\hline Faturamento & Média & Mediana & $\begin{array}{l}\text { Desvio } \\
\text { padrão }\end{array}$ & Mínimo & Máximo \\
\hline $\begin{array}{l}\text { \% do faturamento que foi discriminado } \\
\text { valores }\end{array}$ & 1,69 & 1,07 & 2,37 & 0,00 & 19,69 \\
\hline \% do faturamento com PE & 0,65 & 0,27 & 1,57 & 0,00 & 18,66 \\
\hline \% do faturamento com PM & 1,05 & 0,64 & 1,50 & 0,00 & 14,74 \\
\hline $\begin{array}{l}\text { \% do faturamento com PE - Mão de } \\
\text { obra }\end{array}$ & 0,56 & 0,24 & 1,53 & 0,00 & 18,66 \\
\hline $\begin{array}{l}\text { \% do faturamento com PE - Materiais } \\
\text { \% do faturamento com PM - Mão de }\end{array}$ & $0,0,08$ & 0,00 & 0,28 & 0,00 & 1,78 \\
\hline obra & 0,34 & 1,11 & 0,00 & 9,29 \\
\hline \% do faturamento com PM - Materiais & 0,36 & 0,15 & 0,64 & 0,00 & 5,45 \\
\hline
\end{tabular}

Nos dados da Tabela 9 foram apresentados os valores gastos em reais $(R \$)$; na Tabela 10 , estão apresentados os percentuais (\%) de faturamento relacionados à prescrição de enfermagem e médica. A Tabela 10 demonstra que, em média, $1,69 \%$ do faturamento foi descriminado como prescrição médica ou de enfermagem, e este percentual por paciente pode variar de $0 \%$ a 19,69\%. A prescrição de enfermagem gerou, em média, $0,65 \%$ do faturamento, e este percentual por paciente pode variar de $0 \%$ a $18,66 \%$. Dentre $0,65 \%$ de faturamento gerado pela prescrição de enfermagem, $0,56 \%$ correspondem à mão de obra (com variação entre $0 \%$ a $18,66 \%$ ) e $0,08 \%$, à utilização de materiais de consumo (com variação de $0 \%$ a $1,78 \%$ ). Em média, $1,05 \%$ do faturamento foi descriminado como prescrição médica, e este percentual por paciente pode variar de $0 \%$ a $14,74 \%$. Dentre $1,05 \%$ de faturamento gerado pela prescrição médica, 0,68\% corresponde à mão de obra (com variação de $0 \%$ a 9,29\%) e 0,36\% correspondem à utilização de materiais de consumo pela enfermagem (com variação de $0 \%$ a $5,45 \%$ ). 
Os dados da Tabela 10 contrapõem-se aos achados de Zunta $(2006)^{11}$, no qual a enfermagem contribuía com $15,1 \%$ do faturamento da UTI estudada, sendo 11,3\% gerados pela prescrição de enfermagem e 3,8\% da prescrição médica, assim, a receita gerada pela enfermagem no presente estudo é um valor quase 9 vezes menor ao valor encontrado por Zunta $(2006)^{11}$.

Existem alguns valores pagos pelos materiais no trabalho de Zunta $(2006)^{11}$ há 6 anos que são maiores que os valores pagos atualmente, na instituição estudada. Como exemplo temos a atividade higiene oral, que no trabalho de Zunta (2006) ${ }^{11}$ tinha preço médio de $\mathrm{R} \$ 12,80$ e, atualmente, no hospital estudado, o valor médio é de $R \$ 1,79$, um valor 7 vezes menor. Outro item com valor muito divergente é a atividade de massagem de conforto; no trabalho de Zunta (2006) ${ }^{11}$ o valor pago por cada atividade era de $R \$ 34,99$ e atualmente, na instituição estudada, é de $R \$ 1,39$, um valor 25 vezes menor.

Esta discrepância de resultados entre os dois estudos reflete a realidade da instituição estudada, que, embora atenda apenas operadoras de plano de saúde e pacientes particulares, tem caráter filantrópico e por décadas foi gerenciada por uma associação religiosa, da qual ainda faz parte. Nos últimos cinco anos, os gestores das principais áreas (comercial, recursos humanos, enfermagem, diretoria administrativa, auditoria) foram substituídos por novos profissionais, no intuito de mudar a posição da instituição no mercado de saúde.

$\mathrm{Na}$ instituição hospitalar estudada, o caráter filantrópico ainda tem um forte impacto comercial. A visão de mercado do hospital mudou nos últimos 5 anos e, com isso, as regras contratuais vêm sendo modificadas também; hoje, a diretoria da Instituição procura equiparar seus preços aos praticados no mercado de saúde e, para que isso aconteça, tem revisto contratos comerciais, com negociação de novas tabelas de cobrança. Hoje, procedimentos de enfermagem ainda são cobrados de formas diferentes para distintas operadoras de plano de assistência à saúde. Com isso, o 
hospital não recebe pagamento pela assistência que foi prestada e deixa de aumentar seu faturamento.

Os dados da Tabela 10 evidenciaram que $1,7 \%$ do faturamento da UTI Cardiológica é proveniente das atividades de enfermagem, sendo 0,65\% originado com base na prescrição de enfermagem e 1,05\% na prescrição médica.

Tabela 11 - Faturamento médio gerado a partir das taxas de enfermagem e de materiais utilizados, com base na prescrição de enfermagem, nos meses entre janeiro e março de 2011- São Paulo, 2011

\begin{tabular}{|c|c|c|c|c|c|c|}
\hline Faturamento & $\mathbf{n}$ & Média & Mediana & $\begin{array}{l}\text { Desvio } \\
\text { padrão }\end{array}$ & Mínimo & Máximo \\
\hline $\begin{array}{l}\text { Percentual pago com taxas } \\
\text { (taxas discriminadas) }\end{array}$ & 168 & $0,45 \%$ & $0,17 \%$ & $0,79 \%$ & $0 \%$ & $7,04 \%$ \\
\hline $\begin{array}{l}\text { Percentual pago com materiais (materiais } \\
\text { descriminados) }\end{array}$ & 168 & $1,25 \%$ & $0,68 \%$ & $1,98 \%$ & $0 \%$ & $19,07 \%$ \\
\hline $\begin{array}{l}\text { Qtde. de atividades executadas pela } \\
\text { enfermagem }\end{array}$ & 168 & 76,10 & 41 & 117,62 & 0 & 1105 \\
\hline Total de atividades cobradas & 168 & 38,33 & 20 & 65,12 & 0 & 612 \\
\hline Percentual de atividades cobradas & 168 & $49,01 \%$ & $50 \%$ & $15,89 \%$ & $0 \%$ & $83,87 \%$ \\
\hline
\end{tabular}

Os dados da Tabela 11 mostram que, em média, 0,45\% do faturamento é gerado com base no pagamento de taxas descriminadas nas contas hospitalares (variação de $0 \%$ a 7,04\%); 1,25\% do faturamento advém do pagamento de materiais de consumo, que são utilizados pela enfermagem na prestação da assistência ao paciente (variação de $0 \%$ a 19,07\%). Na amostra estudada, foi encontrado que, em média, a enfermagem executa 76,10 atividades de cuidados (com variação de 0 a 1.105 atividades); destes, ocorre a cobrança média de 38,33 itens descriminados nas contas hospitalares (variação de 0 a 612 atividades), o que correspondem a $49,01 \%$ de pagamento das atividades de enfermagem realizadas (variação de $0 \%$ a $83,7 \%$ ). 


\subsection{PROJEÇÃO DO FATURAMENTO GERADO PELA ENFERMAGEM}

Os dados abaixo são referentes aos faturamentos médios obtidos por paciente do estudo e as projeções de faturamento para 3 meses e para 1 ano.

Tabela 12 - Projeção de faturamento médio por paciente, para os meses entre janeiro e março de 2011 e para 1 ano - São Paulo, 2011

\begin{tabular}{|c|c|c|c|}
\hline & $\begin{array}{l}\text { Média por } \\
\text { paciente }\end{array}$ & $\begin{array}{c}\text { Projeção para o } \\
\text { período de } 3 \text { meses } \\
\text { do estudo }\end{array}$ & $\begin{array}{c}\text { Projeção para } \\
\text { período de } 1 \text { ano }\end{array}$ \\
\hline Faturamento Total (Valor total da conta hospitalar) & $43.045,56$ & $13.731 .533,64$ & $54.926 .134,56$ \\
\hline Faturamento - proc. médicos + proc. enfermagem & 773,98 & $246.899,62$ & $987.598,48$ \\
\hline Faturamento procedimentos de enf. & 333,06 & $106.246,14$ & $424.984,56$ \\
\hline Procedimentos enfermagem - materiais (em reais) & 261,67 & $83.472,73$ & $333.890,92$ \\
\hline Procedimentos enfermagem - mão de obra (em reais) & 71,39 & $22.773,41$ & $91.093,64$ \\
\hline Faturamento procedimentos médicos & 440,92 & $140.653,48$ & $562.613,92$ \\
\hline 'Procedimentos médicos - materiais (em reais)' & 322,51 & $102.880,69$ & $411.522,76$ \\
\hline Procedimentos médicos - mão de obra (em reais) & 118,41 & $37.772,79$ & $151.091,16$ \\
\hline
\end{tabular}

Os dados da Tabela 12 mostram que o valor médio da conta hospitalar, por paciente, foi de $\mathrm{R} \$ 43.045,56$; o valor médio do faturamento gerado com base nas prescrições médicas e de enfermagem foi de $R \$$ 773,98 . Os procedimentos da prescrição de enfermagem geraram um faturamento de $R \$ 333,06$, e $R \$ 261,67$ correspondem aos materiais de consumo utilizados na assistência ao paciente, e $R \$ 71,39$, ao pagamento de taxas. As atividades de enfermagem provenientes da prescrição médica geraram um faturamento de $R \$ 440,92$, e $R \$ 322,51$ correspondem ao pagamento de materiais de consumo e $R \$ 118,41$, ao pagamento de taxas.

Os dados da Tabela 12 evidenciaram ainda a projeção de valores de faturamento ao período de 3 meses do estudo e para o período de 1 ano. 
A projeção do faturamento total da amostra selecionada aos 3 meses de estudo foi de $R \$ 13.731 .533,64$; os procedimentos de enfermagem derivados das prescrições médica e de enfermagem produzirão um faturamento de $R \$ 246.899,62$; a prescrição de enfermagem gerará um valor de $R \$ 106.246,14$, sendo $R \$ 83.472 .73$ correspondente ao uso de materiais de consumo e $\mathrm{R} \$ 22.773,41$ para o pagamento de mão de obra. Os procedimentos realizados com base na prescrição médica produzirão um faturamento de $R \$ 140.653,48$, sendo $R \$ 102.880,69$ correspondente ao uso de materiais de consumo e $R \$ 37.772,79$ para o pagamento de mão de obra.

Os dados da Tabela 12 demonstram que a projeção de faturamento total para o período de 1 ano para a amostra selecionada foi de $R \$$ 54.926.134,56. Os procedimentos realizados, mediante as prescrições médica e de enfermagem produzirão um faturamento de $R \$ 987.598,48$. A prescrição de enfermagem produzirá um faturamento de $R \$ 424.984,56$, sendo $\mathrm{R} \$ 333.890,92$ correspondente ao pagamento de materiais de consumo e $\mathrm{R} \$ 91.093,64$, ao pagamento de taxas. A prescrição médica será responsável pelo faturamento de $R \$ 562.613,92$, sendo $R \$ 411.522,76$ correspondente ao valor pago por materiais de consumo e $\mathrm{R} \$ 151.091,16$, ao pagamento de taxas. 


\subsection{ESTIMATIVA DE PERDA DE FATURAMENTO}

Nesta parte do estudo, o interesse foi avaliar a perda estimada de faturamento para o hospital estudado. Para realizar esta análise, com base nos dados da Tabela 8, foi calculado o percentual de atividades que foram realizadas e não foram cobradas nas contas hospitalares estudadas. Esta análise foi realizada para cada item e depois foi calculado o percentual médio de atividades que não foram pagas.

Tabela 13 - Demonstrativo da estimativa média de perda de faturamento, nos meses entre janeiro e março de 2011 - São Paulo, 2011

\begin{tabular}{|c|c|c|c|c|}
\hline Atividades & $\begin{array}{l}\text { Qtde. de } \\
\text { vezes que } \\
\text { esta } \\
\text { atividade } \\
\text { foi paga }\end{array}$ & $\begin{array}{l}\text { Qtde. de } \\
\text { vezes que } \\
\text { esta } \\
\text { atividade } \\
\text { foi } \\
\text { realizada }\end{array}$ & $\begin{array}{c}\% \text { de } \\
\text { vezes que } \\
\text { a atividade } \\
\text { foi paga }\end{array}$ & $\begin{array}{c}\% \text { de } \\
\text { vezes que } \\
\text { a } \\
\text { atividade } \\
\text { não } \\
\text { foi paga }\end{array}$ \\
\hline Alimentação enteral & 0 & 12 & - & $100,0 \%$ \\
\hline Aplicação de pomadas & 274 & 275 & $99,6 \%$ & $0,4 \%$ \\
\hline $\begin{array}{l}\text { Aspiração traqueostomia/cânula orotraqueal/vias aéreas } \\
\text { superiores }\end{array}$ & 14 & 14 & $100,0 \%$ & - \\
\hline Banho de aspersão & 0 & 328 & & $100,0 \%$ \\
\hline Banho no leito & 10 & 329 & $3,0 \%$ & $97,0 \%$ \\
\hline $\begin{array}{l}\text { Cateter central de inserção periférica - PICC } \\
\text { (passagem, curativos) }\end{array}$ & 15 & 15 & $100,0 \%$ & - \\
\hline Curativo de ferida operatória & 152 & 230 & $66,1 \%$ & $33,9 \%$ \\
\hline Curativo de cateter venoso central & 91 & 114 & $79,8 \%$ & $20,2 \%$ \\
\hline Curativo de dreno & 7 & 62 & $11,3 \%$ & $88,7 \%$ \\
\hline Curativo de traqueostomia & 23 & 23 & $100,0 \%$ & - \\
\hline Curativo de úlcera por pressão & 24 & 24 & $100,0 \%$ & - \\
\hline Glicemia capilar & $2.761 "$ & 2.794 & $98,8 \%$ & $1,2 \%$ \\
\hline Higiene íntima & 0 & 1.502 & - & $100,0 \%$ \\
\hline Higiene ocular & 19 & 204 & $9,3 \%$ & $90,7 \%$ \\
\hline
\end{tabular}




\begin{tabular}{|c|c|c|c|c|}
\hline Atividades & $\begin{array}{l}\text { Qtde. de } \\
\text { vezes que } \\
\text { esta } \\
\text { atividade } \\
\text { foi paga }\end{array}$ & $\begin{array}{c}\text { Qtde. de } \\
\text { vezes que } \\
\text { esta } \\
\text { atividade } \\
\text { foi } \\
\text { realizada }\end{array}$ & $\begin{array}{c}\% \text { de } \\
\text { vezes que } \\
\text { a atividade } \\
\text { foi paga }\end{array}$ & $\begin{array}{c}\text { \% de } \\
\text { vezes que } \\
\text { a } \\
\text { atividade } \\
\text { não } \\
\text { foi paga }\end{array}$ \\
\hline Higiene oral & 286 & 1.545 & $18,5 \%$ & $81,5 \%$ \\
\hline Inalação & 259 & 259 & $100,0 \%$ & - \\
\hline Instalação de placa hidrocoloide & 8 & 8 & $100,0 \%$ & - \\
\hline Instalação de protetor de calcâneos & 14 & 14 & $100,0 \%$ & - \\
\hline Instalar uripen & 28 & 28 & $100,0 \%$ & - \\
\hline Irrigação vesical & 1 & 1 & $100,0 \%$ & - \\
\hline Manta térmica & 1 & 1 & $100,0 \%$ & - \\
\hline Massagem conforto & 1.274 & 1.667 & $76,4 \%$ & $23,6 \%$ \\
\hline Meias elásticas antitrombóticas & 3 & 4 & $75,0 \%$ & $25,0 \%$ \\
\hline Mensuração de capnografia & 93 & 93 & $100,0 \%$ & - \\
\hline Mensuração de pressão intra-abdominal & 2 & 4 & $50,0 \%$ & $50,0 \%$ \\
\hline Mensuração de pressão venosa central & 335 & 1.212 & $27,6 \%$ & $72,4 \%$ \\
\hline Monitorização de marca-passo tem porário & 5 & 5 & $100,0 \%$ & - \\
\hline Nutrição parenteral & "'0" & 3 & $-"-$ & "'100,0\%" \\
\hline Ordenha de dreno & 0 & 46 & $=$ & $100,0 \%$ \\
\hline Preparo de corpo pós-óbito & 0 & 7 & - & $100,0 \%$ \\
\hline $\begin{array}{l}\text { Pressão arterial invasiva (curativo, troca de transdutor, } \\
\text { passagem) }\end{array}$ & 63 & 67 & $94,0 \%$ & $6,0 \%$ \\
\hline Realização de diálise peritoneal intermitente & 2 & 2 & $100,0 \%$ & - \\
\hline Realização de enteroclisma & 44 & 44 & $100,0 \%$ & - \\
\hline $\begin{array}{l}\text { Realização } \\
\text { eletrocardiograma }\end{array}$ & 172 & 197 & $87,3 \%$ & $12,7 \%$ \\
\hline Restrição/ enfaixamento de membros inferiores & 30 & 174 & $17,2 \%$ & $82,8 \%$ \\
\hline Retirada de introdutor percutâneo & 0 & 2 & - & $100,0 \%$ \\
\hline Sondagem gástrica/enteral & 23 & 23 & $100,0 \%$ & - \\
\hline Sondagem retal & 2 & 2 & $100,0 \%$ & - \\
\hline
\end{tabular}




\begin{tabular}{|c|c|c|c|c|}
\hline Atividades & $\begin{array}{l}\text { Qtde. de } \\
\text { vezes que } \\
\text { esta } \\
\text { atividade } \\
\text { foi paga }\end{array}$ & $\begin{array}{l}\text { Qtde. de } \\
\text { vezes que } \\
\text { esta } \\
\text { atividade } \\
\text { foi } \\
\text { realizada }\end{array}$ & $\begin{array}{c}\% \text { de } \\
\text { vezes que } \\
\text { a atividade } \\
\text { foi paga }\end{array}$ & $\begin{array}{c}\text { \% de } \\
\text { vezes que } \\
\text { a } \\
\text { atividade } \\
\text { não } \\
\text { foi paga }\end{array}$ \\
\hline Sondagem vesical & 27 & 27 & $100,0 \%$ & - \\
\hline Transporte de paciente intra-hospitalar & 0 & 72 & - & $100,0 \%$ \\
\hline Tricotomia facial & 2 & 58 & $3,4 \%$ & $96,6 \%$ \\
\hline Tricotomia pré-operatória & "'7 & 24 & $29,2 \%$ & $70,8 \%$ \\
\hline Troca de bolsa de colostomia & 0 & 1 & - & $100,0 \%$ \\
\hline Troca de filtro bacteriano & 112 & 112 & $100,0 \%$ & - \\
\hline Troca de selo d'água de dreno & 49 & 54 & $90,7 \%$ & $9,3 \%$ \\
\hline Verificar peso & 0 & 852 & - & $100,0 \%$ \\
\hline MÉDIA & & & $61,68 \%$ & $38,32 \%$ \\
\hline
\end{tabular}

Os dados da Tabela 13 evidenciam que as atividades de enfermagem relacionadas à higiene (banho no leito, banho de aspersão, higiene oral, higiene íntima) estão entre os procedimentos que não recebem pagamento pela sua execução. Por exemplo, a atividade banho no leito foi realizada 329 vezes, porém em apenas dez vezes recebeu pagamento. Desta forma, em $97 \%$ das vezes em que a atividade foi executada, não foi paga.

Os dados da Tabela 13 mostram que as atividades de banho de aspersão, ordenha de dreno, preparo de corpo pós-óbito, retirada de introdutor venoso, transporte intra-hospitalar e mensuração de peso não receberam pagamento em nenhum dos prontuários contábeis analisados.

Para todos os itens da Tabela 8, foi feita a mesma análise e, assim, chegou-se ao valor que, em média, 38,32\% das vezes que as atividades de enfermagem foram realizadas, não foram cobradas na conta dos pacientes estudados e, portanto, não geraram faturamento. 
Existem alguns itens, como atividades de higiene (banho no leito, banho de aspersão, higiene íntima, higiene oral, tricotomia facial) e curativos que podem estar incluídos na diária hospitalar de UTI, não sendo, portanto descriminados e cobradas na conta hospitalar. No entanto, os autores deste estudo não tiveram acesso aos contratos comerciais firmados entre as operadoras de assistência à saúde e a instituição hospitalar estudada e, portanto o estudo tem a limitação de não saber ao certo, o que cada operadora de assistência à saúde paga ou não ao hospital.

Tabela 14 - Projeção de perda média estimada de faturamento para os meses entre janeiro e março de 2011e para 1 ano de faturamento - São Paulo, 2011

\begin{tabular}{|c|c|c|c|c|c|}
\hline & $\begin{array}{c}\text { Faturamento } \\
\text { (proc. médicos } \\
\text { + proc. } \\
\text { Enfermagem) } \\
\text { Média por } \\
\text { paciente }\end{array}$ & $\begin{array}{c}\text { Perda } \\
\text { estimada } \\
\text { por } \\
\text { paciente }\end{array}$ & $\begin{array}{c}\text { Perda } \\
\text { estimada } \\
\text { para o total } \\
\text { da amostra } \\
\text { coletada }\end{array}$ & $\begin{array}{c}\text { Projeção de } \\
\text { perda para o } \\
\text { período de } 3 \\
\text { meses do } \\
\text { estudo }\end{array}$ & $\begin{array}{c}\text { Projeção de } \\
\text { perda para } \\
\text { o período } \\
\text { de } 1 \text { ano }\end{array}$ \\
\hline & 773,98 & 480,85 & $81.263,65$ & $153.391,15$ & $613.564,60$ \\
\hline
\end{tabular}

Os dados da Tabela 14 demonstram que a prescrição de enfermagem somada à prescrição médica gera um faturamento médio, por paciente, de $\mathrm{R} \$ 773,98$ e a perda média estimada, por paciente, foi de $\mathrm{R} \$ 480,95$.

A perda média estimada para o total da amostra coletada foi de $R \$$ 81.263,65; a projeção de estimativa de perda média de faturamento para os 3 meses do estudo foi de $\mathrm{R} \$ 153.391,15$; extrapolando para o período de um ano, teremos uma projeção de estimativa de perda média de faturamento de $\mathrm{R} \$ 613.564,60$. 
Tabela 15 - Projeção de faturamento médio sem perda monetária, por paciente, entre os meses de janeiro e março de 2011 e para 1 ano de faturamento - São Paulo, 2011

\begin{tabular}{lcccc}
\hline & $\begin{array}{c}\text { Faturamento } \\
\text { (proc. médicos + } \\
\text { proc. } \\
\text { Enfermage m) } \\
\text { Média por } \\
\text { paciente } \\
\text { (considerando } \\
\text { que não } \\
\text { houvesse perda) }\end{array}$ & $\begin{array}{c}\text { Faturamento } \\
\text { estimado para } \\
\text { o para o total } \\
\text { da amostra } \\
\text { coletada }\end{array}$ & $\begin{array}{c}\text { Projeção } \\
\text { faturamento } \\
\text { para o } \\
\text { período de 3 } \\
\text { meses do } \\
\text { estudo }\end{array}$ & $\begin{array}{c}\text { Projeção de } \\
\text { faturamento } \\
\text { para o } \\
\text { período de 1 } \\
\text { ano }\end{array}$ \\
\hline Procedimentos médicos + & $1.254,83$ & $212.066,27$ & $400.290,77$ & $1.601 .163,08$ \\
Procedimentos Enfermagem & & & & \\
\hline
\end{tabular}

Os dados da Tabela 15 demonstram que, se não houvesse existido perda monetária na amostra estudada, o faturamento gerado pelas atividades de enfermagem seria de $\mathrm{R} \$ 1.254,83$ por paciente, o que corresponde a $2,9 \%$ do faturamento da amostra estudada. O faturamento total estimado, sem perda monetária, para a amostra seria de $\mathrm{R} \$$ 212.066,27. A projeção de faturamento para o período dos 3 meses de estudo seria de $R \$ 400.290,77$, sem perda financeira. A projeção de faturamento para o período de 1 ano para a amostra estudada seria de $\mathrm{R} \$$ $1.601 .163,08$.

A projeção de 2,9\% relacionada à participação das atividades de enfermagem no faturamento ainda foi muito inferior ao achado de Zunta $(2006)^{11}$, cujos dados mostraram que as atividades de enfermagem eram responsáveis por $15,1 \%$ do faturamento estudado. 


\subsection{COMPARAÇÕES DE FATURAMENTO ENTRE AS VARIÁVEIS}

$\mathrm{Na}$ análise a seguir, foi realizada a comparação da média dos diversos faturamentos avaliados no estudo em relação a três principais operadoras de planos de assistência à saúde e um grupo de outras operadoras. Foram consideradas as primeiras operadoras, pois com base na quarta operadora, havia menos de 10 indivíduos.

Para a comparação entre as operadoras, o teste utilizado foi a Análise de Variância (ANOVA). Para a utilização deste teste, foi verificado se, para cada resultado, as variâncias eram homogêneas entre os grupos (suposição para a utilização). Como houve situações em que não foi verificada homogeneidade das variâncias, nestas situações, foi feito o ajuste por meio do teste de Brown-Forsythe (BF). Quando houve diferença significante entre os grupos, para a identificação de quais operadoras de plano de assistência à saúde apresentam diferenças entre si foram feitas comparações múltiplas (comparações entre dois a dois grupos), utilizando o teste de Bonferroni. Estas comparações foram apresentadas ao final da tabela geral, apontando diferença, quando p-valor $<0,05$ (foi considerado um nível de significância de 5\%).

Para facilitar a interpretação e ilustrar o resultado do teste que apresentou diferenças entre os grupos, foi construído o gráfico de perfil. 
Tabela 16 - Comparativo médio dos faturamentos avaliados no estudo em relação as três principais operadoras de plano de assistência à saúde e um grupo de outras operadoras nos meses entre janeiro e março de 2011 - São Paulo, 2011

\begin{tabular}{|c|c|c|c|c|c|c|}
\hline & & \multicolumn{4}{|c|}{ OPERADORA } & \multirow{2}{*}{$\begin{array}{l}\text { Valor } \\
\text { de } p\end{array}$} \\
\hline & & $\mathbf{A}$ & B & C & Outras & \\
\hline \multirow{6}{*}{$\begin{array}{l}\text { Prescrição de enfermagem - } \\
\text { total }\end{array}$} & $n$ & 43 & 30 & 14 & 82 & \multirow{6}{*}{0,754} \\
\hline & Média & 304,4 & 239,4 & 84,6 & 424,8 & \\
\hline & Mediana & 51,0 & 92,0 & 56,1 & 68,6 & \\
\hline & Desvio padrão & 947,0 & 371,9 & 78,5 & $1.624,5$ & \\
\hline & Mínimo & 0,0 & 0,0 & 0,0 & 0,0 & \\
\hline & Máximo & $5.387,9$ & 1702,0 & 216,5 & $14.218,2$ & \\
\hline \multirow{6}{*}{$\begin{array}{l}\text { Prescrição de enfermagem - } \\
\text { material }\end{array}$} & $\mathbf{n}$ & 43 & 30 & 14 & 82 & \multirow{6}{*}{0,710} \\
\hline & Média & 304,4 & 139,6 & 84,6 & 314,2 & \\
\hline & Mediana & 51,0 & 90,1 & 56,1 & 54,2 & \\
\hline & Desvio padrão & 947,0 & 176,8 & 78,5 & $1.129,9$ & \\
\hline & Mínimo & 0,0 & 0,0 & 0,0 & 0,0 & \\
\hline & Máximo & $5.387,9$ & 911,2 & 216,5 & $9.622,6$ & \\
\hline \multirow{6}{*}{$\begin{array}{l}\text { Prescrição de enfermagem - } \\
\text { mão de obra }\end{array}$} & $\mathbf{n}$ & 43 & 30 & 14 & 82 & \multirow{6}{*}{$\begin{array}{l}0,383 \\
(\mathrm{t})\end{array}$} \\
\hline & Média & 0 & 99,9 & 0 & 110,6 & \\
\hline & Mediana & 0 & 0,0 & 0 & 0,0 & \\
\hline & Desvio padrão & 0 & 233,9 & 0 & 521,8 & \\
\hline & Mínimo & 0 & 0,0 & 0 & 0,0 & \\
\hline & Máximo & 0 & 863,1 & 0 & $4.595,6$ & \\
\hline \multirow{6}{*}{ Prescrição médica - total } & $\mathbf{n}$ & 43 & 30 & 14 & 82 & \multirow{6}{*}{$\begin{array}{l}0,196 \\
\text { (BF) }\end{array}$} \\
\hline & Média & 232,6 & 690,4 & 166,7 & 505,7 & \\
\hline & Mediana & 56,9 & 215,0 & 77,1 & 115,2 & \\
\hline & Desvio padrão & 494,5 & $1.600,1$ & 271,5 & $1.272,8$ & \\
\hline & Mínimo & 0,0 & 18,6 & 10,3 & 0,0 & \\
\hline & Máximo & $2.412,0$ & $7.353,1$ & $1.063,3$ & $8.177,5$ & \\
\hline
\end{tabular}




\begin{tabular}{|c|c|c|c|c|c|c|}
\hline & & \multicolumn{4}{|c|}{ OPERADORA } & \multirow{2}{*}{$\begin{array}{l}\text { Valor } \\
\text { de } p\end{array}$} \\
\hline & & $\mathbf{A}$ & B & C & Outras & \\
\hline \multirow{6}{*}{ Prescrição médica - material } & $\mathbf{n}$ & 43 & 30 & 14 & 82 & \multirow{6}{*}{0,655} \\
\hline & Média & 204,0 & 422,4 & 159,2 & 376,0 & \\
\hline & Mediana & 49,3 & 87,9 & 63,9 & 59,6 & \\
\hline & Desvio padrão & 463,8 & $1.208,1$ & 270,4 & $1.119,8$ & \\
\hline & Mínimo & 0,0 & 11,4 & 10,3 & 0,0 & \\
\hline & Máximo & $2.378,6$ & $5.065,9$ & $1.050,1$ & $6.873,4$ & \\
\hline \multirow{6}{*}{$\begin{array}{l}\text { Prescrição médica - Mao de } \\
\text { obra }\end{array}$} & $\mathbf{n}$ & 43 & 30 & 14 & 82 & \multirow{6}{*}{$\begin{array}{l}0,013 \\
(\mathrm{BF})\end{array}$} \\
\hline & Média & 28,6 & 268,0 & 7,6 & 129,7 & \\
\hline & Mediana & 13,1 & 118,1 & 13,2 & 34,2 & \\
\hline & Desvio padrão & 52,1 & 560,0 & 6,8 & 255,3 & \\
\hline & Mínimo & 0,0 & 0,0 & 0,0 & 0,0 & \\
\hline & Máximo & 220,2 & $2.719,0$ & 13,2 & $1.505,7$ & \\
\hline \multirow{6}{*}{$\begin{array}{l}\text { Total de valores } \\
\text { discriminados }\end{array}$} & $\mathbf{n}$ & 43 & 30 & 14 & 82 & \multirow{6}{*}{0,602} \\
\hline & Média & 536,9 & 929,9 & 251,3 & 930,5 & \\
\hline & Mediana & 113,7 & 339,4 & 153,2 & 220,2 & \\
\hline & Desvio padrão & $1.332,6$ & $1.878,7$ & 321,4 & $2.756,5$ & \\
\hline & Mínimo & 0,0 & 30,2 & 21,9 & 0,0 & \\
\hline & Máximo & $7.174,5$ & $9.055,2$ & $1.273,1$ & $22.395,7$ & \\
\hline
\end{tabular}

(t) para esta comparação foi utilizado o teste t-Student por haver informação apenas para dois grupos

Pelos resultados da Tabela 16, nota-se que, em média, apenas houve diferença do faturamento para prescrição médica (honorários) entre as operadoras de plano de assistência à saúde $(p<0,05)$. Para identificar quais operadoras diferenciavam-se entre si, foram realizadas as comparações múltiplas.

Os dados da Tabela 16 mostram que a operadora de saúde $B$, embora tenha $69 \%$ do número de pacientes da operadora $A$ (30 pacientes e 
43 pacientes, respectivamente), o faturamento médio gerado pela operadora $B$ foi muito superior, financeiramente, em relação à operadora $A(173 \%)$. Isto demonstra que o contrato comercial entre o Hospital e a operadora de saúde $B$ deve ter sido reajustado recentemente, com um pagamento melhor em relação às taxas e materiais de consumo, pois, como se nota pelos resultados da Tabela 16, o faturamento médio relacionado ao pagamento de taxas de enfermagem foi de $R \$ 99,9$ e de materiais, de $R \$ 422,4$ para a operadora de saúde $B$.

A diferença de faturamento entre as operadoras de saúde ocorreu em razão de acordos comerciais realizados entre a operadora e o hospital. Assim, enquanto algumas operadoras de saúde aceitam o pagamento de taxas referentes a procedimentos, outras repassam o valor correspondente apenas aos materiais utilizados nos procedimentos, não levando em consideração a mão de obra empregada na atividade. A importância do enfermeiro na negociação de contratos comerciais reside no fato de que este tem conhecimento de todos os procedimentos que são realizados na assistência ao paciente, bem como do tempo despendido para cada atividade e dos materiais necessários para sua execução.

$\mathrm{Na}$ instituição de saúde estudada, como em muitas outras, o prontuário contábil é elaborado por um auxiliar de faturamento, um profissional administrativo que não tem conhecimento dos processos assistenciais envolvidos no cuidado ao paciente. A confecção da conta hospitalar demanda entendimento não só sobre as tabelas e contratos comerciais acordados entre as operadoras de saúde e o hospital, mas também de como ocorrem os procedimentos assistenciais dentro da instituição de saúde, como forma de assegurar que todas as taxas, materiais, medicamentos e honorários que foram consumidos na prestação do cuidado ao cliente, possam ser cobrados das operadoras, gerando receita à organização de saúde. 
Tabela 17 - Comparações múltiplas entre as três principais operadoras de saúde e um grupo de outras operadoras, para a amostra estudada, nos meses entre janeiro e março de 2011 - São Paulo, 2011

\begin{tabular}{cccc}
\hline \multicolumn{3}{c}{ Comparações } & p-valor \\
\hline A & X & B & 0,144 \\
\hline A & X & C & 0,076 \\
\hline A & X & Outros & 0,005 \\
\hline B & X & C & 0,091 \\
\hline B & X & Outros & 0,722 \\
\hline C & Outros & $<0,001$ \\
\hline & & & \\
\hline
\end{tabular}

Os dados da Tabela 17 evidenciam que apenas houve diferença do grupo com outras operadoras de plano de assistência à saúde em relação à operadora $A$ e $C(p<0,05)$, mostrando que o grupo de outras operadoras apresentou, em média, maior faturamento do que as outras operadoras ( $\mathrm{A}$ e C). 


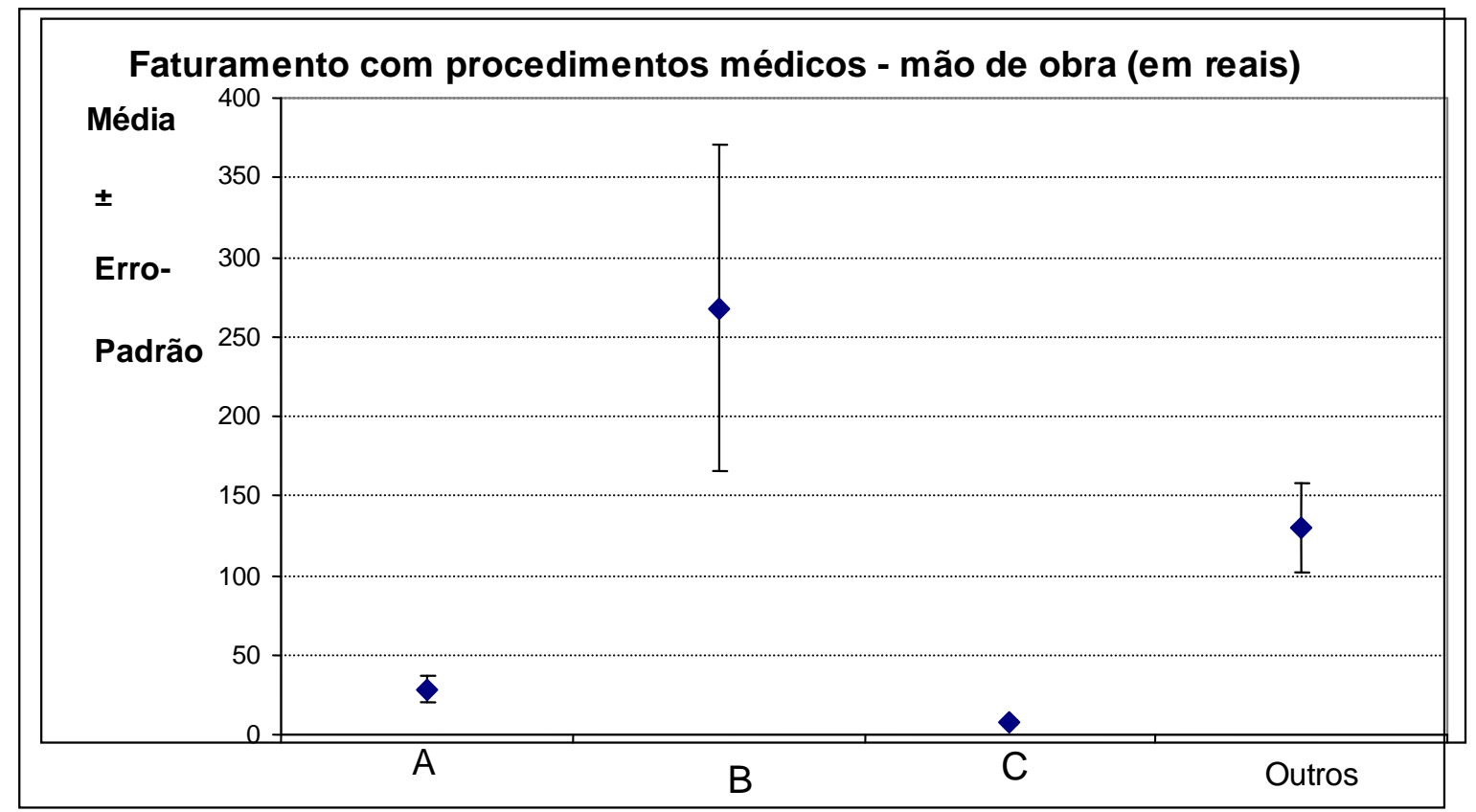

Figura 1 - Comparação múltipla entre as três principais operadoras de plano de assistência à saúde e um grupo de outras operadoras, em relação ao faturamento gerado pela prescrição médica - São Paulo, 2011

Os dados apresentados na Tabela 17 e na Figura 1 demonstram que há uma grande quantidade de operadoras de planos de assistência à saúde com poucos pacientes em cada uma delas. Além disso, os dados mostram que existe uma grande variabilidade no faturamento de cada operadora (alto desvio padrão), o que faz com que não sejam evidenciadas diferenças entre os faturamentos das operadoras. Desta forma, os resultados poderiam ser apresentados apenas descritivamente, sem a necessidade de testes. 
Tabela 18 - Comparativo entre as 3 maiores e as 3 menores operadoras de saúde, em relação à forma de remuneração ao hospital, para a amostra estudada, nos meses entre janeiro e março de 2011 - São Paulo, 2011

\begin{tabular}{|c|c|c|c|c|c|c|c|c|c|c|c|c|c|c|c|c|c|c|}
\hline \multirow{3}{*}{ ATIVIDADES } & \multicolumn{18}{|c|}{ OPERADORAS DE SAÚDE } \\
\hline & \multicolumn{3}{|c|}{ A } & \multicolumn{3}{|c|}{ B } & \multicolumn{3}{|c|}{ C } & \multicolumn{3}{|c|}{$A C$} & \multicolumn{3}{|c|}{$A D$} & \multicolumn{3}{|c|}{ AE } \\
\hline & $\begin{array}{c}\text { MA } \\
T\end{array}$ & TX & $\begin{array}{c}\text { TOT } \\
\text { AL }\end{array}$ & MAT & TX & $\begin{array}{l}\text { TOT } \\
\text { AL }\end{array}$ & $\begin{array}{c}\text { MA } \\
T\end{array}$ & TX & $\begin{array}{l}\text { TOT } \\
\text { AL }\end{array}$ & $\begin{array}{c}\text { MA } \\
T\end{array}$ & TX & $\begin{array}{l}\text { TOT } \\
\text { AL }\end{array}$ & MAT & TX & $\begin{array}{l}\text { TOT } \\
\text { AL }\end{array}$ & $\begin{array}{c}\text { MA } \\
T\end{array}$ & TX & $\begin{array}{c}\text { TOT } \\
\text { AL }\end{array}$ \\
\hline $\begin{array}{c}\text { Alimentação } \\
\text { enteral }\end{array}$ & 0 & 0 & 0 & 0 & 0 & 0 & 0 & 0 & 0 & 0 & 0 & 0 & 0 & 0 & 0 & 0 & 0 & 0 \\
\hline $\begin{array}{l}\text { Aplicação de } \\
\text { pomadas }\end{array}$ & $\begin{array}{l}29 \\
82\end{array}$ & 0 & $\begin{array}{c}29,8 \\
2\end{array}$ & 7,78 & 0 & 7,78 & 0 & 0 & 0 & 0 & 0 & 0 & $\begin{array}{c}32,2 \\
3\end{array}$ & 0 & $\begin{array}{c}32,2 \\
3\end{array}$ & 0 & 0 & 0 \\
\hline $\begin{array}{c}\text { Aspiração } \\
\text { traqueostomia/c } \\
\text { anula } \\
\text { orotraqueal/vias } \\
\text { aéreas } \\
\text { superiores }\end{array}$ & 0 & 0 & 0 & 0 & 0 & 0 & 0 & 0 & 0 & 0 & 0 & 0 & 0 & 0 & 0 & 0 & 0 & 0 \\
\hline $\begin{array}{l}\text { Banho } \\
\text { aspersão }\end{array}$ & 0 & 0 & 0 & 0 & 0 & 0 & 0 & 0 & 0 & 0 & 0 & 0 & 0 & 0 & 0 & 0 & 0 & 0 \\
\hline Banho no leito & 0 & 0 & 0 & 0 & 0 & 0 & 0 & 0 & 0 & 0 & 0 & 0 & 0 & 0 & 0 & 0 & 0 & 0 \\
\hline Capnografia & 0 & 0 & 0 & 0 & 0 & 0 & 0 & 0 & 0 & 0 & 0 & 0 & 0 & $\begin{array}{c}56,8 \\
2\end{array}$ & $\begin{array}{c}56,8 \\
2\end{array}$ & 0 & 0 & 0 \\
\hline $\begin{array}{l}\text { Curativo cateter } \\
\text { venoso central }\end{array}$ & $\begin{array}{l}21, \\
08\end{array}$ & 0 & $\begin{array}{c}21,0 \\
8\end{array}$ & 0 & 0 & 0 & 0 & 0 & 0 & $\begin{array}{l}17 \\
47\end{array}$ & 0 & $\begin{array}{c}17,4 \\
7\end{array}$ & $\begin{array}{c}13,5 \\
1\end{array}$ & 0 & $\begin{array}{c}13,5 \\
1\end{array}$ & 0 & 0 & 0 \\
\hline $\begin{array}{l}\text { Curativo de } \\
\text { dreno }\end{array}$ & 0 & 0 & 0 & 0 & 0 & 0 & 0 & 0 & 0 & 0 & 0 & 0 & 0 & 0 & 0 & 0 & 0 & 0 \\
\hline $\begin{array}{l}\text { Curativo ferida } \\
\text { operatória }\end{array}$ & 0 & 0 & 0 & 0 & 0 & 0 & $\begin{array}{l}59 \\
00\end{array}$ & 0 & $\begin{array}{c}59,0 \\
0\end{array}$ & $\begin{array}{c}9,4 \\
6\end{array}$ & 0 & 9,46 & $\begin{array}{c}10,3 \\
2\end{array}$ & $\begin{array}{c}11,6 \\
7\end{array}$ & $\begin{array}{c}21,9 \\
9\end{array}$ & 0 & 0 & 0 \\
\hline $\begin{array}{l}\text { Curativo } \\
\text { traqueostomia }\end{array}$ & 0 & 0 & 0 & 0 & 0 & 0 & 0 & 0 & 0 & 0 & 0 & 0 & 0 & 0 & 0 & 0 & 0 & 0 \\
\hline $\begin{array}{l}\text { Curativo de } \\
\text { úlcera pressão }\end{array}$ & $\begin{array}{l}57, \\
09\end{array}$ & 0 & $\begin{array}{c}57,0 \\
9\end{array}$ & 0 & 0 & 0 & 0 & 0 & 0 & 0 & 0 & 0 & 0 & 0 & 0 & 0 & 0 & 0 \\
\hline Glicemia capilar & $\begin{array}{c}5,4 \\
9\end{array}$ & 0 & 5,49 & 3,81 & $\begin{array}{c}7,2 \\
8\end{array}$ & $\begin{array}{c}11,0 \\
9\end{array}$ & $\begin{array}{c}5,1 \\
5\end{array}$ & $\begin{array}{c}0,0 \\
0\end{array}$ & 5,15 & $\begin{array}{l}11 \\
09\end{array}$ & $\begin{array}{c}0,0 \\
0\end{array}$ & $\begin{array}{c}11,0 \\
9\end{array}$ & 4,01 & 5,15 & 9,16 & $\begin{array}{c}4,6 \\
2\end{array}$ & $\begin{array}{c}0,0 \\
0\end{array}$ & 4,62 \\
\hline $\begin{array}{c}\text { Diálise } \\
\text { peritoneal } \\
\text { intermitente }\end{array}$ & 0 & 0 & 0 & 0 & 0 & 0 & 0 & 0 & 0 & 0 & 0 & 0 & 0 & 0 & 0 & 0 & 0 & 0 \\
\hline $\begin{array}{c}\text { Eletrocardiogra } \\
\text { ma }\end{array}$ & 0 & $\begin{array}{l}12 \\
15\end{array}$ & $\begin{array}{c}12,1 \\
5\end{array}$ & 0 & 0 & 0 & 0 & $\begin{array}{l}13 \\
23\end{array}$ & $\begin{array}{c}13,2 \\
3\end{array}$ & 0 & $\begin{array}{c}4,6 \\
2\end{array}$ & 4,62 & 0 & $\begin{array}{c}12,6 \\
0\end{array}$ & $\begin{array}{c}12,6 \\
0\end{array}$ & 0 & 0 & 0 \\
\hline Enteroclisma & $\begin{array}{c}6,3 \\
1\end{array}$ & 0 & 6,31 & $\begin{array}{c}13,0 \\
6\end{array}$ & $\begin{array}{c}0,0 \\
0\end{array}$ & $\begin{array}{c}13,0 \\
6\end{array}$ & 0 & 0 & 0 & 0 & 0 & 0 & 7,26 & $\begin{array}{c}32,5 \\
3\end{array}$ & $\begin{array}{c}39,7 \\
9\end{array}$ & 0 & 0 & 0 \\
\hline $\begin{array}{l}\text { Higiene couro } \\
\text { cabeludo }\end{array}$ & 0 & 0 & 0 & 0 & 0 & 0 & 0 & 0 & 0 & 0 & 0 & 0 & 0 & 0 & 0 & 0 & 0 & 0 \\
\hline Higiene íntima & 0 & 0 & 0 & 0 & 0 & 0 & 0 & 0 & 0 & 0 & 0 & 0 & 0 & 0 & 0 & 0 & 0 & 0 \\
\hline Higiene ocular & 0 & 0 & 0 & 0 & 0 & 0 & 0 & 0 & 0 & 0 & 0 & 0 & 0,52 & 0 & 0,52 & 0 & 0 & 0 \\
\hline Higiene oral & 0 & 0 & 0 & 0 & 0 & 0 & 0 & 0 & 0 & 0 & 0 & 0 & 0 & 0 & 0 & 0 & 0 & 0 \\
\hline Inalação & 0 & 0 & 0 & 0 & $\begin{array}{c}3,0 \\
1\end{array}$ & 3,01 & 0 & 0 & 0 & 0 & 0 & 0 & 0 & 0 & 0 & 0 & 0 & 0 \\
\hline $\begin{array}{c}\text { Instalação de } \\
\text { placa } \\
\text { hidrocoloide }\end{array}$ & 0 & 0 & 0 & 0 & 0 & 0 & 0 & 0 & 0 & 0 & 0 & 0 & 0 & 0 & 0 & 0 & 0 & 0 \\
\hline $\begin{array}{l}\text { Instalação de } \\
\text { protetor de } \\
\text { calcâneos }\end{array}$ & 0 & 0 & 0 & 0 & 0 & 0 & 0 & 0 & 0 & 0 & 0 & 0 & $\begin{array}{c}19,5 \\
6\end{array}$ & 0 & $\begin{array}{c}19,5 \\
6\end{array}$ & 0 & 0 & 0 \\
\hline Instalar uripen & 0 & 0 & 0 & 0 & 0 & 0 & 0 & 0 & 0 & 0 & 0 & 0 & 0 & 0 & 0 & 0 & 0 & 0 \\
\hline Irrigação vesical & 0 & 0 & 0 & 0 & 0 & 0 & 0 & 0 & 0 & 0 & 0 & 0 & 0 & 0 & 0 & 0 & 0 & 0 \\
\hline Manta térmica & 0 & 0 & 0 & 0 & 0 & 0 & 0 & 0 & 0 & 0 & 0 & 0 & 0 & 0 & 0 & 0 & 0 & 0 \\
\hline Marca-passo & 0 & 0 & 0 & 0 & 0 & 0 & 0 & 0 & 0 & 0 & 0 & 0 & 0 & 0 & 0 & 0 & 0 & 0 \\
\hline $\begin{array}{l}\text { Massagem de } \\
\text { conforto }\end{array}$ & $\begin{array}{l}11, \\
57\end{array}$ & 0 & $\begin{array}{c}11,5 \\
7\end{array}$ & $\begin{array}{c}11,5 \\
7\end{array}$ & 0 & $\begin{array}{c}11,5 \\
7\end{array}$ & $\begin{array}{l}11, \\
57\end{array}$ & $\begin{array}{c}0,0 \\
0\end{array}$ & $\begin{array}{c}11,5 \\
7\end{array}$ & $\begin{array}{c}0,0 \\
0\end{array}$ & 0 & 0 & $\begin{array}{c}11,5 \\
7\end{array}$ & 0 & $\begin{array}{c}11,5 \\
7\end{array}$ & $\begin{array}{l}10, \\
41\end{array}$ & 0 & $\begin{array}{c}10,4 \\
1\end{array}$ \\
\hline
\end{tabular}




\begin{tabular}{|c|c|c|c|c|c|c|c|c|c|c|c|c|c|c|c|c|c|c|}
\hline \multirow{3}{*}{ ATIVIDADE } & \multicolumn{18}{|c|}{ OPERADORAS DE SAÚDE } \\
\hline & \multicolumn{3}{|c|}{ A } & \multicolumn{3}{|c|}{ B } & \multicolumn{3}{|c|}{ C } & \multicolumn{3}{|c|}{$A C$} & \multicolumn{3}{|c|}{$A D$} & \multicolumn{3}{|c|}{$\mathrm{AE}$} \\
\hline & $\begin{array}{c}\text { MA } \\
\text { T }\end{array}$ & $\mathrm{TX}$ & $\begin{array}{c}\text { TOT } \\
\text { AL }\end{array}$ & MAT & TX & $\begin{array}{c}\text { TOT } \\
\text { AL }\end{array}$ & $\begin{array}{c}\text { MA } \\
T\end{array}$ & TX & $\begin{array}{c}\text { TOT } \\
\text { AL }\end{array}$ & $\begin{array}{c}\text { MA } \\
T\end{array}$ & TX & $\begin{array}{c}\text { TOT } \\
\text { AL }\end{array}$ & MAT & TX & $\begin{array}{l}\text { TOT } \\
\text { AL }\end{array}$ & $\begin{array}{c}\text { MA } \\
T\end{array}$ & TX & $\begin{array}{c}\text { TOT } \\
\text { AL }\end{array}$ \\
\hline $\begin{array}{c}\text { Meias } \\
\text { antitrombóticas }\end{array}$ & 0 & 0 & 0 & 0 & 0 & 0 & 0 & 0 & 0 & 0 & 0 & 0 & 0 & 0 & 0 & 0 & 0 & 0 \\
\hline $\begin{array}{c}\text { Nutrição } \\
\text { parenteral }\end{array}$ & 0 & 0 & 0 & 0 & 0 & 0 & 0 & 0 & 0 & 0 & 0 & 0 & 0 & 0 & 0 & 0 & 0 & 0 \\
\hline $\begin{array}{c}\text { Ordenha de } \\
\text { dreno }\end{array}$ & 0 & 0 & 0 & 0 & 0 & 0 & 0 & 0 & 0 & 0 & 0 & 0 & 0 & 0 & 0 & 0 & 0 & 0 \\
\hline $\begin{array}{l}\text { Pressão Intra- } \\
\text { abdominal }\end{array}$ & 0 & 0 & 0 & 0 & 0 & 0 & 0 & 0 & 0 & 0 & 0 & 0 & 0 & 0 & 0 & 0 & 0 & 0 \\
\hline $\begin{array}{c}\text { PICC (cateter } \\
\text { central de } \\
\text { inserção } \\
\text { periférica) }\end{array}$ & 0 & 0 & 0 & 0 & 0 & 0 & 0 & 0 & 0 & 0 & 0 & 0 & 0 & 0 & 0 & 0 & 0 & 0 \\
\hline $\begin{array}{c}\text { Preparo de } \\
\text { corpo pós-óbito }\end{array}$ & 0 & 0 & 0 & 0 & 0 & 0 & 0 & 0 & 0 & 0 & 0 & 0 & 0 & 0 & 0 & 0 & 0 & 0 \\
\hline Punção venosa & $\begin{array}{l}26, \\
32\end{array}$ & 0 & $\begin{array}{c}26,3 \\
2\end{array}$ & $\begin{array}{c}37,2 \\
9\end{array}$ & 0 & $\begin{array}{c}37,2 \\
9\end{array}$ & $\begin{array}{l}36, \\
09\end{array}$ & 0 & $\begin{array}{c}36,0 \\
9\end{array}$ & 0 & 0 & 0 & $\begin{array}{c}46,4 \\
3\end{array}$ & 0 & $\begin{array}{c}46,4 \\
3\end{array}$ & 0 & 0 & 0 \\
\hline $\begin{array}{l}\text { Pressão venosa } \\
\text { central }\end{array}$ & 0 & 0 & 0 & 0 & 0 & 0 & $\begin{array}{l}10 \\
14\end{array}$ & 0 & $\begin{array}{c}10,1 \\
4\end{array}$ & 0 & 0 & 0 & 0 & 4,07 & 4,07 & 0 & 0 & 0 \\
\hline $\begin{array}{l}\text { Restrição/ } \\
\text { enfaixamento } \\
\text { de membros } \\
\text { inferiores }\end{array}$ & 0 & 0 & 0 & 0 & 0 & 0 & $\begin{array}{l}16 \\
51\end{array}$ & 0 & $\begin{array}{c}16,5 \\
1\end{array}$ & 0 & 0 & 0 & $\begin{array}{c}37,6 \\
3\end{array}$ & 0 & $\begin{array}{c}37,6 \\
3\end{array}$ & 0 & 0 & 0 \\
\hline $\begin{array}{l}\text { Retirada de } \\
\text { introdutor } \\
\text { percutâneo }\end{array}$ & 0 & 0 & 0 & 0 & 0 & 0 & 0 & 0 & 0 & 0 & 0 & 0 & 0 & 0 & 0 & 0 & 0 & 0 \\
\hline $\begin{array}{l}\text { Sondagem } \\
\text { gástrica/ enteral }\end{array}$ & 0 & 0 & 0 & 0 & 0 & 0 & 0 & 0 & 0 & 0 & 0 & 0 & $\begin{array}{c}537 \\
90\end{array}$ & $\begin{array}{c}308 \\
56\end{array}$ & $\begin{array}{c}846 \\
46\end{array}$ & 0 & 0 & 0 \\
\hline $\begin{array}{l}\text { Sondagem } \\
\text { vesical }\end{array}$ & 0 & 0 & 0 & $\begin{array}{c}109 \\
86\end{array}$ & 0 & $\begin{array}{c}109 \\
86\end{array}$ & 0 & 0 & 0 & 0 & 0 & 0 & 0 & 0 & 0 & 0 & 0 & 0 \\
\hline Sondagem retal & $\begin{array}{l}15 \\
69\end{array}$ & 0 & $\begin{array}{c}15,6 \\
9\end{array}$ & 0 & 0 & 0 & 0 & 0 & 0 & 0 & 0 & 0 & 0 & 0 & 0 & 0 & 0 & 0 \\
\hline $\begin{array}{l}\text { Transporte de } \\
\text { paciente }\end{array}$ & 0 & 0 & 0 & 0 & 0 & 0 & 0 & 0 & 0 & 0 & 0 & 0 & 0 & 0 & 0 & 0 & 0 & 0 \\
\hline $\begin{array}{c}\text { Tricotomia } \\
\text { facial }\end{array}$ & 0 & 0 & 0 & 0 & 0 & 0 & 0 & 0 & 0 & 0 & 0 & 0 & 0 & 0 & 0 & 0 & 0 & 0 \\
\hline $\begin{array}{c}\text { Tricotomia pré- } \\
\text { operatória }\end{array}$ & 0 & 0 & 0 & 0 & 0 & 0 & 0 & 0 & 0 & 0 & 0 & 0 & 0 & 0 & 0 & 0 & 0 & 0 \\
\hline $\begin{array}{l}\text { Troca de bolsa } \\
\text { de colostomia }\end{array}$ & 0 & 0 & 0 & 0 & 0 & 0 & 0 & 0 & 0 & 0 & 0 & 0 & 0 & 0 & 0 & 0 & 0 & 0 \\
\hline $\begin{array}{l}\text { Troca de filtro } \\
\text { bacteriano }\end{array}$ & 0 & 0 & 0 & 0 & 0 & 0 & 0 & 0 & 0 & 0 & 0 & 0 & $\begin{array}{c}105 \\
30\end{array}$ & 0 & $\begin{array}{c}105 \\
30\end{array}$ & 0 & 0 & 0 \\
\hline $\begin{array}{l}\text { Troca de selo } \\
\text { d'água de dreno }\end{array}$ & 0 & 0 & 0 & 0 & 0 & 0 & 0 & 0 & 0 & $\begin{array}{l}11 \\
27\end{array}$ & 0 & $\begin{array}{c}11,2 \\
7\end{array}$ & 0 & 0 & 0 & 0 & 0 & 0 \\
\hline Verificar peso & 0 & 0 & 0 & 0 & 0 & 0 & 0 & 0 & 0 & $\begin{array}{c}0,0 \\
0\end{array}$ & 0 & 0 & 0 & 0 & 0 & 0 & 0 & 0 \\
\hline
\end{tabular}

Os dados da Tabela 18 demonstram a forma de remuneração, de cada atividade do estudo, entre as três maiores operadoras (em número de atendimentos) e as três menores, da amostra pesquisada. Pode-se perceber, pelos dados expostos, que os procedimentos são pagos ao hospital de formas diferentes, entre as operadoras, ratificando o que já foi 
exposto anteriormente, sobre a importância do enfermeiro na elaboração das tabelas e contratos comerciais, como forma de assegurar o adequado valor e pagamento pela assistência prestada. O item enteroclisma, por exemplo, apresenta três diferentes remunerações, entre as operadoras, $e$ as operadoras A e B pagam apenas o material utilizado no procedimento; as operadoras $C, A C$ e $A E$ não pagam o material e/ou taxa relacionada à atividade, causando perda monetária ao hospital; apenas a operadora $A D$ paga tanto o material como a taxa relacionada ao procedimento. 


\section{CONCLUSÕES}

O objetivo deste estudo foi identificar o valor do faturamento gerado pelos procedimentos de enfermagem, mediante as prescrições médica e de enfermagem, descrever as atividades de enfermagem que são realizadas, mas não recebem pagamento pelas operadoras de saúde e estimar a perda monetária do hospital pela não taxação das atividades de enfermagem.

Assim, concluiu-se com esta pesquisa que:

- A média de idade dos clientes da amostra foi de 63,8 anos, com um tempo médio de internação na UTI Cardiológica de 4,5 dias e um tempo médio de internação hospitalar de 10,2 dias. Não houve diferença estatística significativa em relação ao gênero dos pacientes estudados, com $52,4 \%$ da amostra sendo do gênero feminino e 47,6\%, do masculino;

- Houve uma predominância de diagnósticos médicos clínicos na amostra selecionada, e este perfil manteve-se quando foi analisada a taxa de ocupação da UTI Cardiológica nos meses entre janeiro e junho de 2011;

- A porcentagem de diagnósticos médicos clínicos foi de $61,3 \%$ dos pacientes, e a porcentagem de diagnósticos médicos cirúrgicos foi $38,7 \%$;

- Entre os diagnósticos médicos clínicos, os mais incidentes foram síndrome coronariana aguda (13,8\% da amostra) e insuficiência respiratória aguda (13,8\% da amostra). Entre os diagnósticos médicos cirúrgicos, os mais incidentes foram os procedimentos de revascularização do miocárdio e angioplastia coronariana com stent. Tanto os diagnósticos médicos clínicos como os cirúrgicos têm identificação com a unidade estudada;

- Quanto às operadoras de plano de assistência à saúde, as três mais frequentes (A, B e C) respondem juntas, por $51,7 \%$ do faturamento da amostra, e as operadoras A e B, juntas, respondem por $43,4 \%$ do faturamento da amostra para o período estudado;

- Os faturamentos médios gerados pelas prescrições de enfermagem e médica foram de $R \$ 773,98$, e $R \$ 333,06$ corresponderam à prescrição de enfermagem e $R \$ 440,92$, à prescrição médica; e

- Em relação ao valor gerado pela prescrição de enfermagem $(\mathrm{R} \$ 333,06)$, $R \$ 261,67$ corresponderam ao pagamento de materiais de consumo e $\mathrm{R} \$ 71,39$, ao pagamento de taxas. 
- $\quad$ Em relação ao valor gerado pela prescrição médica ( $R \$ 440,92), R \$$ 322,51 corresponderam ao pagamento de materiais de consumo e $R \$$ 118,41 , ao pagamento de taxas.

- Alguns procedimentos realizados pela enfermagem foram $100 \%$ pagos pelas operadoras; são eles:

- Curativo de traqueostomia;

- Irrigação vesical;

- Instalação de uripen;

- Monitorização de marca-passo temporário;

- Passagem de sonda vesical;

- Mensuração de pressão intra-abdominal;

- Inalação;

- Passagem de sonda gástrica/enteral;

- Troca de filtro bacteriano;

- Mensuração de capnografia;

- Instalação de placa hidrocoloide;

- Instalação de protetor de calcâneos;

- Cateter central de inserção periférica - PICC (passagem e curativos);

- Passagem de sonda retal;

- Aspiração de traqueostomia, cânula orotraqueal e vias aéreas superiores;

- Instalação de manta térmica;

- Realização de diálise peritoneal intermitente; e

- Realização de enteroclisma.

- $\quad$ Os dados da Tabela 8 evidenciam 48 procedimentos realizados pela enfermagem; destes, 18 procedimentos (37,5\%) têm 100\% de pagamento pelas operadoras de saúde.

- Os procedimentos da prescrição de enfermagem que mais contribuíram para o faturamento, foram a troca de filtro bacteriano ( $R \$$ $10.342,80)$, a realização de punção venosa ( $R \$ 8.062,99)$, o curativo de ferida operatória $(R \$ 5.315,26)$ e o curativo de traqueostomia $(R \$ 4.762,42)$; 
- Os procedimentos provenientes da prescrição médica que mais geraram faturamento foram a realização de glicemia capilar ( $R \$ 21.602,06)$, passagem de pressão arterial invasiva $(R \$ 14.220,56)$ e a passagem de sonda gástrica/enteral ( $R \$ 20.239,00)$;

- Os procedimentos de enfermagem de banho de aspersão, ordenha de dreno, preparo de corpo pós-óbito, retirada de introdutor venoso, transporte intra-hospitalar e mensuração de peso não receberam pagamento em nenhum dos prontuários contábeis analisados;.

- O valor médio da conta hospitalar de cada paciente da amostra foi de $R \$ 43.045,56$. A projeção do faturamento médio, por paciente, para o período dos 3 meses do estudo foi de $R \$ 13.731 .533,64$. Extrapolando a projeção para 1 ano, para a amostra selecionada, evidencia um valor de faturamento médio de $\mathrm{R} \$ 54.926 .124,56$;

- A análise dos procedimentos de enfermagem que foram realizados e não foram pagos demonstrou uma estimativa de perda média de $R \$ 480,65$ por paciente da amostra. A estimativa média de perda para a amostra estudada foi de $R \$ 81.263,65$. A projeção de perda média de faturamento, para o período dos 3 meses do estudo, para a amostra selecionada, foi de $R \$ 153.391$,15. A extrapolação da estimativa de perda média para o período de 1 ano, para a amostra selecionada, foi de $\mathrm{R} \$ 613.564,60$; e

- Do faturamento total da amostra selecionada, as atividades de enfermagem contribuem com $1,7 \%$ do faturamento, e $0,65 \%$ corresponderam aos procedimentos executados, mediante a prescrição de enfermagem e $1,05 \%$, aos procedimentos provenientes da prescrição médica;

- Em relação ao pagamento de taxas, $0,45 \%$ das taxas presentes nos prontuários contábeis eram relacionadas às taxas de enfermagem;

- A enfermagem executou uma média de 76,10 atividades por paciente da amostra, e 38,33 destas atividades receberam pagamento $(49,01 \%$ do total de atividades executadas);

- Se não houvesse existido perda monetária na amostra estudada, o faturamento gerado pelas atividades de enfermagem seria de $R \$ 1.254,83$ 
por paciente, o que corresponde a 2,9\% do faturamento da amostra estudada.;

- O faturamento total estimado, sem perda monetária, para a amostra seria de $R \$ 212.066,27$. A projeção de faturamento para o período dos 3 meses de estudo seria de $R \$ 400.290,77$, sem perda financeira. A projeção de faturamento para o período de 1 ano para a amostra estudada seria de $\mathrm{R} \$ 1.601 .163,08$.

- A análise do faturamento por operadoras de plano de assistência à saúde revelou que a operadora $\mathrm{B}$, embora seja a segunda em número de pacientes da amostra, apresenta um valor de faturamento gerado, sobretudo em relação ao pagamento de taxas, superior às operadoras $\mathrm{A}$ e $\mathrm{C}$;

- Em relação ao faturamento entre as operadoras de plano de assistência à saúde, os dados mostram que não há uma grande variabilidade no faturamento para cada operadora; $e$

- Um comparativo entre a forma de remuneração pelas atividades do estudo entre as três maiores operadoras de saúde (em número de atendimentos) e as três menores demonstrou que os procedimentos são pagos de formas diferentes, entre as operadoras, o que denota acordos comerciais muito díspares, causando perda monetária para o hospital. 


\section{CONSIDERAÇÕES FINAIS}

Conhecer o quanto a enfermagem contribui para o faturamento de uma UTI e para o faturamento de um hospital é evidenciar, financeiramente, a importância do trabalho desse profissional.

Este estudo identificou e descreveu quais são as atividades de enfermagem realizadas em uma UTI Cardiológica, quais destas atividades constam em prontuário contábil e são pagas pelas operadoras de saúde, quais procedimentos de enfermagem não recebem pagamento e estimou a perda média de faturamento para a UTI e ao hospital estudado. A falta de estudos sobre a temática dificulta a realização de comparações.

Nos últimos anos, a instituição de saúde deste estudo passa por uma reforma administrativa, no intuito de mudar seu posicionamento no mercado de saúde cada vez mais competitivo. No entanto, é preciso que ocorra também uma mudança da cultura da instituição, o que implica no aprimoramento de sistemas de contabilização, não só para o faturamento, mas também para a gestão de custos à enfermagem, por meio de um sistema de informação gerencial, que auxilie os gestores no planejamento e tomada de decisões. Atualmente, os enfermeiros responsáveis por unidades de serviço dentro da instituição estudada lidam apenas com o orçamento, mas não conhecem a rentabilidade da assistência prestada em suas unidades.

A área de Auditoria do hospital foi totalmente reformulada, com a substituição dos profissionais por enfermeiros assistenciais da própria instituição, que atuavam na assistência direta a pacientes. Com isso, esperase que o conhecimento adquirido no cuidado direto a pacientes críticos possa reverter a situação de falta de pagamento pelo cuidado prestado pela enfermagem no hospital de estudo. É esperado também que a idealização, contratação e negociação dos contratos comerciais com as operadoras de saúde sejam realizadas com a participação de enfermeiros, que são os profissionais com conhecimento técnico-científico sobre o que está sendo 
cobrado; com isso, o que a enfermagem executa pode ser efetivamente cobrado, podendo aumentar o faturamento do hospital.

Na organização de saúde do estudo, o auditor ainda não exerce sua função educativa sobre a enfermagem, conforme é esperado. As atividades de melhoria da assistência baseadas em um programa de educação continuada em serviço dos colaboradores não se faz presente na instituição onde a pesquisa ocorreu, e o auditor atua apenas no fechamento das contas hospitalares, sem ter envolvimento na análise do cuidado que está sendo prestado.

A apreciação dos prontuários contábeis evidenciou uma discrepância muito grande em relação ao pagamento de taxas. Assim, o mesmo procedimento foi cobrado de formas diferentes entre as operadoras de plano de assistência à saúde.

Existem algumas atividades, como passagem de PICC, que não constam em nenhum dos prontuários contábeis analisados. Este procedimento ocorre com muita frequência na UTI estudada, porém a enfermagem não é remunerada financeiramente por ele.

Neste estudo, o baixo faturamento gerado pela enfermagem deve-se ao não pagamento das atividades executadas e às baixas taxas negociadas entre o hospital e as operadoras de saúde. Cabe ressaltar que foram valoradas apenas "algumas" das atividades diretas realizadas pela enfermagem, sem contemplar aquelas atividades indiretas que a enfermagem executa na assistência ao paciente. Além disso, existem atividades que são realizadas e que estão "embutidas" na diária do paciente, diminuindo a geração de receita pela enfermagem.

Este estudo possui algumas limitações, como a falta de acesso da pesquisadora aos contratos e tabelas acordadas entre 0 hospital e as operadoras de saúde; sendo assim, não foi possível esclarecer o que cada operadora paga ou não ao hospital, bem como o que cada diária hospitalar contempla. 
Outra limitação do estudo foi a ausência de padronização de cobrança dos procedimentos de enfermagem nos prontuários contábeis. A análise dos prontuários contábeis evidenciou que, geralmente, não havia correspondência com a conta hospitalar, com a ausência de itens de materiais de consumo. A falta de padronização dos procedimentos de enfermagem gera cobranças diferentes para a mesma atividade, causando divergências entre o que é realizado e o que é cobrado, podendo ocasionar glosas pelas operadoras de saúde. Por exemplo, os materiais necessários para a realização de uma punção venosa são descriminados com todos os materiais consumidos naquela unidade de serviço; sendo assim, a pesquisadora relacionou os materiais de cada procedimento realizado, mediante seu conhecimento prévio sobre os insumos do hospital em questão. Um fator que pode contribuir para esta situação é a manuseio dos prontuários clínicos por profissionais que não são enfermeiros e, portanto, não sabem quais materiais são utilizados em cada procedimento de enfermagem. A falta de padronização dos procedimentos de enfermagem também foi encontrada nos resultados de Zunta (2006). ${ }^{11}$

A pesquisa propôs-se a verificar o quanto financeiramente a enfermagem tem contribuído para o faturamento de um hospital, mas novos estudos devem ser feitos, para que os resultados possam ser medidos e comparados entre hospitais de diferentes naturezas jurídicas. 


\section{REFERÊNCIAS}

1. Francisco IMF, Castilho V. A enfermagem e o gerenciamento de custos. Rev Esc Enferm USP. 2002;36(3):240-4.

2. Johnson AC. Administração de hospitais. São Paulo: Pioneira; 1979.

3. Sandroni P. Dicionário de administração e finanças. São Paulo: Best Seller; 2001.

4. Falk JA. Gestão de custos para hospitais: conceitos, metodologias e aplicações. São Paulo: Atlas; 2001.

5. Mendes KGL. A participação das enfermeiras na gestão de custos em organizações hospitalares [tese doutorado]. São Paulo: Escola de Enfermagem, Universidade de São Paulo; 2011.

6. Zunta RSB, Castilho V. Faturamento de procedimentos de enfermagem em uma Unidade de Terapia Intensiva. Rev Latino Am Enferm [Internet]. 2011 [citado 2012 abr. 19];19(3):573-580. Disponível em: http://www.scielo.br/pdf/rlae/v19n3/pt_17.pdf

7. Aburdene $P$, Naisbitt J. Megatendências para as mulheres. Rio de Janeiro: Rosa dos Tempos; 1993.

8. Consejo Internacional de Enfermeras. La calidad, los costos y la enfermeria. [Apresentado no dia Internacional da la Enfermera, Geneva; 1993].

9. Aiken LH. Economics of nursing. Policy Polit Nurs Pract. 2008;9(2):739.

10. Rodrigues Filho J. Sistema de Classificação de Pacientes. Parte II: custo de enfermagem. Rev EscEnferm USP. 1994;28(1):41-9.

11.Zunta RSB. O faturamento gerado pelos procedimentos de enfermagem em uma unidade de terapia intensiva [dissertação]. São Paulo: Escola de Enfermagem; Universidade de São Paulo; 2006.

12. Griffith $\mathrm{H}$, Ott BB, Towers J. Who gets the money? Am J Nurs. 1989;89(2):186-8.

13. Santos SS, Carvalho EC. Análise de custo na enfermagem: revisão integrativa. Online Braz J Nurs. 2008;7(3):1-12.

14. Munhoz S, Barros SMO. Conhecimento dos gestores dos serviços de enfermagem sobre custos hospitalares. Rev Paul Enferm. 2002;21(1):30-9.

15. Dallora MELV. Gerenciamento de custos de material de consumo de um hospital de ensino [dissertação]. Ribeirão Preto: Faculdade de Medicina de Ribeirão Preto, Universidade de São Paulo; 2007. 
16. Pellegrini G. Auditoria em faturamento. In: Anais eletrônico do Congresso Latino Americano de Serviços de Saúde e $3^{\text {a }}$ Jornada de Gestão e Clínicas Médicas; 2004; São Paulo, SP, Brasil [CD-ROM].

17. Rodrigues VA, Perroca MG, Jericó MC. Glosas hospitalares: importância das anotações de enfermagem. Arq Ciênc Saúde. 2004;11(4):201-4.

18. Kurcgant $P$, coordenadora. Gerenciamento em enfermagem. $2^{\underline{a}}$ ed. Rio de Janeiro: Guanabara Koogan; 2010.

19. Scarparo AF, Ferraz CA. Auditoria em enfermagem: identificando sua concepção e métodos. Rev Bras Enferm. 2008;61(3):302-5.

20. Motta ALC. Auditoria de enfermagem nos hospitais e operadoras de planos de saúde. São Paulo: látria; 2003.

21. Observatório ANAHP - Associação Nacional de Hospitais Reforma do modelo de remuneração dos hospitais na saúde suplementar - a visão ANAHP. [On-line]. São Paulo, 2012. [citado 08 de julho de 2012).Disponível em:

http://www.anahp.com.br/files/observatorio_anahp_2012_miolo_210x2 97_web.pdf.

22. (Silva, A.A. Relação entre operadoras de planos de saúde e prestadores de serviço - um novo relacionamento estratégico. [Internet]. Porto Alegre, 2003. [citado 2012 jul.08]. Disponível em http://www.ans.gov.br/portal/upload/biblioteca/TT_AR_6_AAlvesdaSilv a_RelacaoOperadorasPlanos.pdf).

23. Zunta RSB, Cardoso MLAP, Lisboa MARLP, Castilho V. Treinamento com foco no faturamento assistencial: uma inovação no serviço de educação continuada. Mundo Saúde. 2006;30(2):250-5.

24. Buzatti CV, Chianca TC. Auditoria em enfermagem: erros e custos envolvidos nas anotações. Nursing (São Paulo). 2005;8(90):518-22.

25. Galvão CR. Estudo do papel da auditoria de enfermagem para redução dos desperdícios em materiais e medicamentos. Mundo Saúde. 2002;26(2):275-82.

26. Luz A, Martins AP, Dynewicz AM. Características de anotações de enfermagem encontradas em auditoria. Rev Eletr Enferm [Internet]. 2007 [citado 2012 mar. 19];9(2):344-61. Disponível em: http://www.fen.ufg.br/revista/v9/n2/pdf/v9n2a05.pdf

27. Setz VG, D'Innocenzo M. Avaliação da qualidade dos registros de enfermagem no prontuário por meio da auditoria. Acta Paul Enferm. 2009;22(3):313-7.

28. Miranda DR, Ryan DW, Schaufeli WB, Filbler V. Organization and management of intensive care: a prospective study in 12 european countries. Berlin (GER): Springer-Verlag; 1998.

29. Martins E. Contabilidade de custos. $5^{\underline{a}}$ ed. rev. São Paulo: Atlas; 2003. 
30. Conselho Regional de Medicina do Estado de São Paulo (CREMESP). Prontuário e segredo médico [Internet]. São Paulo; 2012 [citado 2012 mar. 28]. Disponível em:

http://www.cremesp.org.br/?siteAcao=PublicacoesConteudoSumario\& id $=57$

31. Padronização da Codificação de Procedimento para Apresentação de Conta Hospitalar [Internet]. [citado 2012 mar. 28]. Disponível em: http://www.ahesp.com.br/padronizacao3.htm

32. Yin RK. Estudo de caso: planejamento e métodos. Trad. de Ana Thorell. 4르. ed. Porto Alegre: Bookman; 2010.

33. Polit DF, Beck CT. Fundamentos de pesquisa em enfermagem: avaliação de evidências para a prática da enfermagem. $7^{\underline{a}}$ ed. Porto Alegre: Artmed; 2011.

34. (Trevizan, M.A., Mendes, I.A.C., Fávero,N., Melo,M.R.A.C. Liderança e comunicação no cenário da gestão em enfermagem. Rev. LatinoAm. Enfermagem [periódico na Internet]. 1998 Dez [citado 2012 Jul 10]; 6(5): 77-82. Disponível em:

http://www.scielo.br/scielo.php?script=sci_arttext\&pid=S010411691998000500010\&lng=pt. http://dx.doi.org/10.1590/S010411691998000500010)

35. Sociedade Brasileira de Cardiologia; Associação Brasileira do Climatério. I Diretriz Brasileira sobre Prevenção de Doenças Cardiovasculares em Mulheres Climatéricas e a Influência da Terapia de Reposição Hormonal - TRH. Arq Bras Cardiol. 2008;91(1 Supl.1):1-23.

36. Campos, C.C .Um estudo das relações entre operadoras de planos de assistência à saúde e prestadoras de serviço. O Mundo da Saúde. 2006;abr/jun,30(2):228-238. 
APÊNDICES 


\section{APÊNDICE A - Instrumento para coleta de dados a partir da prescrição de enfermagem}

NOME DO PACIENTE:

DIAGNÓSTICO INICIAL:

DATA DE INTERNAÇÃO:

CONTEÚDO DA PE

Banho no leito

Banho de aspersão

Tricotomia facial

Higiene oral

Higiene ocular

Higiene íntima

Massagem de

conforto

Curativo FO

Curativo CVC

Aplicação de

pomadas

Verificar peso

Higiene do couro

cabeludo

Instalar uripen
ATENDIMENTO:

CONVENIO:

DATA DA INTERNAÇÃO NA UTI:

DATA DA ALTA DA UTI:

EXO:

IDADE:

DATA DA ALTA HOSP

\section{DIAS DE INTERNAÇÃO: \\ DIASDE INTERNACCAO:
VALOR DO}

\begin{tabular}{|l|l|l|l|}
\hline QTDE. & VALOR & VALOR DO & VALOR TOTAL \\
\hline
\end{tabular} TOTAL PROCED. DO PROCED.

\begin{tabular}{|llllllllll}
\hline Instalar uripen & \\
\hline
\end{tabular}


APÊNDICE B - Instrumento para coleta de dados a partir da prescrição médica

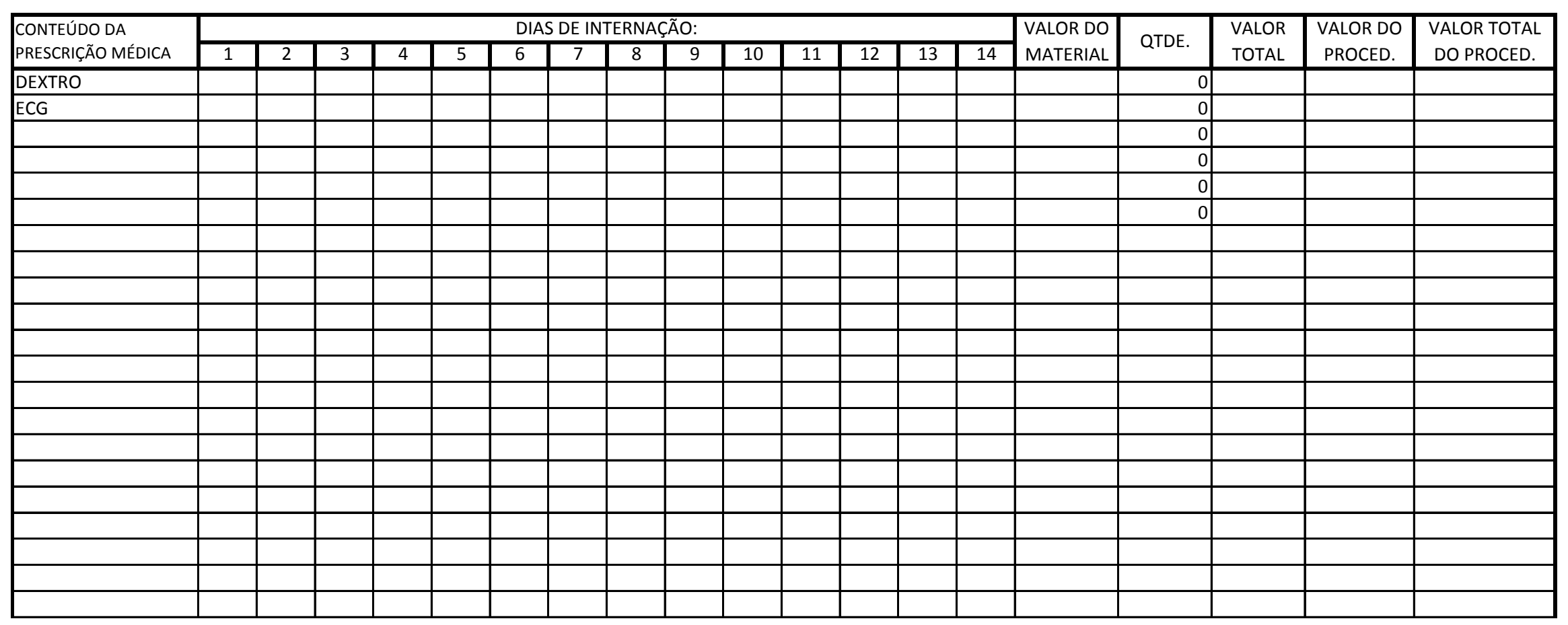


ANEXOS

\title{
Autorização do Comitê de Ética em Pesquisa emitido pelo
}

\author{
Comitê de Ética em Pesquisa - CEPEHSC
}

São Paulo, 13 de junho de 2011

CEP $071 / 11$

IIma. Sra.

Renata Valeria Longo Teixeira

Disciplina: Enfermagem

Projeto de pesquisa intitulado: "O Faturamento das Açöes de Enfermagem e seu Impacto na Conta Hospitalar"

Prezada Pesquisadora,

O Comilê de Etica em Pesquisa CEPEHSC ANALISOU A APROVOU o projeto de pesquisa acima referenciado.

Conforme resoluçäo $196 / 96$ do Conselho Nacional de Saúde săo deveres do pesquisador:

1. Comunicar toda e qualquer alteração do projeto e do termo de consentimento. Nestas circunstãncias a inclusão de pacientes deve ser temporariamente interrompida até a resposta do Comitê, após análise das mudanças propostas.

2. Comunicar imediatamente ao Comitê qualquer evento adverso ocorrido durante o desenvolvimento do estudo.

3. Os dados individuais de todas as etapas da pesquisa devem ser mantidos em local seguro por 5 anos para possivel auditoria dos órgãos competentes.

4. Apresentar primeiro relatório parcial em 13/dezembro/2011

5. Apresentar segundo relatorio parcial em $13 /$ junhol2012

Atenciosamente

Atenciosamente

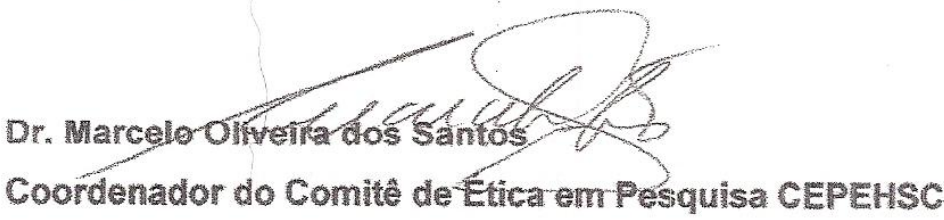

"Ressaltamos que é de essencial importancia que seja verificado, antes da divulgaçäo dos processos elou resultados abtidos nesta pesquisa, se os mesmos säo potencialmente patenteaveis ou passiveis de outras formas de proteçäo intelectualindustrial. A proteção por meio do depósito de patente, ou de outras formas de proteça da propriedade intelectual, evita a açăo indevida de terceiros e confere maior segurança quando da publicaçắo dos resultados da pesquisa." 